\title{
Roberto Sergio Martins
}

\section{Avaliação da eficácia do reparo na regeneração do nervo ciático do rato com utilização de sutura, adesivo de fibrina ou combinação das duas técnicas}

Tese apresentada ao Departamento de Neurologia da Faculdade de Medicina da Universidade de São Paulo para obtenção do título de Doutor em Ciências

Área de concentração: Neurologia

Orientador: Prof. Dr. José Píndaro Pereira Plese

São Paulo

2004 
Este estudo foi aprovado pela Comissão de Ética para Análise de Projetos de Pesquisa da Diretoria Clínica do Hospital das Clínicas e da Faculdade de Medicina da Universidade de São Paulo com o número 309/01. 


\section{DEDICATÓRIAS}

Aos meus pais, pelo exemplo de vida e por me darem as condições para ultrapassar mais este obstáculo, meu profundo reconhecimento.

À Patrícia, pelo seu amor, paciência e compreensão, divido com você a autoria deste trabalho.

Aos meus filhos. Guilherme, a sua alegria, mesmo com a minha ausência nos primeiros momentos de nossa convivência, foi um estímulo para a conclusão deste estudo. Henrique, seja bem-vindo...

Aos meus irmãos e aos meus sogros pelo apoio e incentivo. 


\section{AGRADECIMENTOS}

Ao Prof. Dr. José Píndaro Pereira Plese pela orientação, dedicação e amizade que possibilitaram a realização desta Tese, meus sinceros agradecimentos e a minha admiração.

Ao Prof. Dr. Ciro Ferreira da Silva pelo fundamental apoio, estímulo e pelo trabalho na preparação histológica dos nervos.

Ao Prof. Dr. Raul Marino Jr pela oportunidade de conduzir este trabalho no Laboratório de Neurocirurgia Experimental e pela minha formação em Neurocirurgia.

Ao Dr. Mario Gilberto Siqueira, exemplo de dedicação acadêmica, pelo incentivo, por sua amizade e auxílio na elaboração e execução deste projeto.

Ao Prof. Dr. César Timo-Iaria pelo apoio, incentivo constante e oportunidade de convivência.

Ao Dr. Fábio Luiz Franceschi Godinho pelo auxílio inestimável durante o início deste trabalho.

Ao Bioengenheiro Benedito Ortiz de Godoy pelo auxílio na elaboração da avaliação eletrofisiológica do projeto deste estudo e pela colaboração na avaliação dos resultados.

Ao Dr. Wen Hung Tzu pelo auxílio com a tradução dos artigos escritos em chinês.

Aos colegas César Augusto Seculin, Paulo Roberto Napoli e Osmar José dos Santos de Moraes, pelo apoio e incentivo. 
Aos funcionários do Laboratório de Neurocirurgia Experimental - Lim 45 e do Laboratório de Neurobiologia - I.C.B., que contribuíram para a realização deste trabalho. 
Esta tese está de acordo com:

Referências: adaptado de International Committe of Medical Journals Editors (Vancouver)

Universidade de São Paulo. Faculdade de Medicina. Serviço de Biblioteca e Documentação. Guia de apresentação de dissertações, teses e monografias. Elaborado por Anneliese Carneiro da Cunha, Maria Julia de A. L. Freddi, Maria F. Crestana, Marinalva de Souza Aragão, Suely Campos Cardoso, Valéria Vilhena. São Paulo: Serviço de Biblioteca e Documentação; 2004.

Abreviatura dos títulos dos periódicos de acordo com List of Journals Indexed in Index Medicus. 


\section{SUMÁRIO}

Lista de Abreviaturas

Lista de Figuras

Lista de Símbolos

Lista de Tabelas

Resumo

Summary

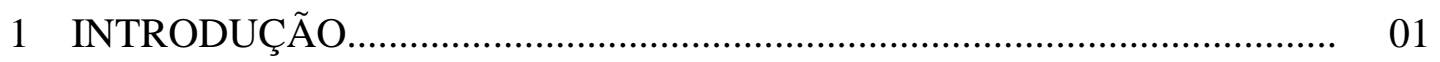

2 REVISÃO DA LITERATURA......................................................... 04

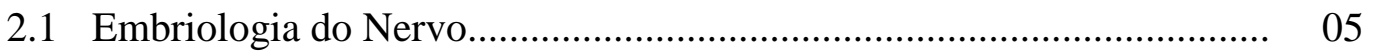

2.2 Histologia do Nervo ................................................................ 13

2.3 Fisiologia do Nervo ................................................................ 22

2.4 O Processo de Regeneração no Sistema Nervoso Periférico ................ 27

2.5 Métodos Experimentais de Avaliação da Regeneração dos Nervos...... 46

2.6 Técnicas Empregadas no Reparo de Lesões de Nervos......................... 51

2.6.1 Histórico ............................................................................... 51

2.6.2 Utilização de Condutores no Reparo de Lesões de Nervos........... 56

2.6.3 Técnicas Empregadas na Coaptação de Nervos Seccionados....... 57

2.6.4 Utilização de Adesivos na Coaptação de Nervos Seccionados..... 60

3 OBJETIVO

4 MÉTODOS

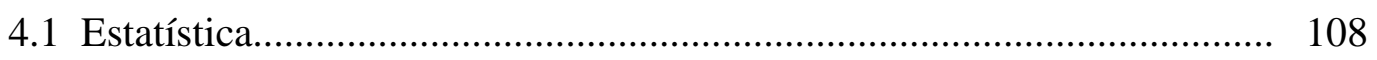

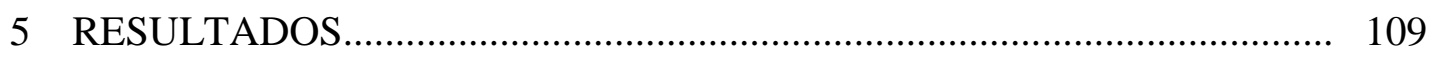

5.1 Avaliação Funcional da Marcha.......................................................... 110 
5.2 Avaliação Eletrofisiológica ........................................................... 112

5.1.1 Avaliação do Potencial de Ação do Nervo.................................. 112

5.1.2 Avaliação do Potencial de Ação Motor ..................................... 116

5.3 Avaliação Histomorfométrica ....................................................... 121

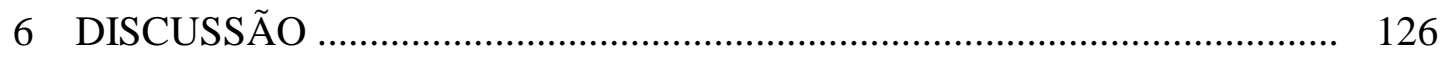

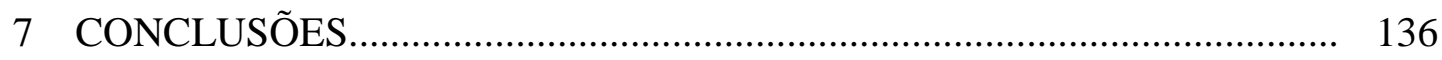

8 ANEXOS

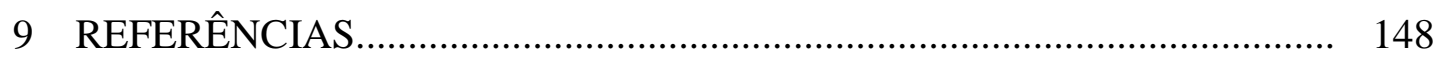




\section{LISTA DE ABREVIATURAS}

AMPM1

AMPM2

AMPN1

AMPN2

a.C.

BDNF

CAM

CNTF

$\mathrm{CP}$

CPD

CPE

$\mathrm{CPN}$

CPO

CS

d.C.

DD

DDD

DDE

DDN

DDO

DI

DID amplitude do potencial de ação motor pré-operatório

amplitude do potencial de ação motor pós-operatório

amplitude do potencial de ação do nervo pré-operatório

amplitude do potencial de ação do nervo pós-operatório

antes de Cristo

"brain-derived neurotrophic factor"

moléculas de adesão celular

"ciliary neurotrophic factor"

comprimento da pegada

comprimento da pegada da pata direita

comprimento da pegada da pata esquerda

comprimento da pegada da pata no lado não operado

comprimento da pegada da pata no lado operado

células de Schwann

depois de Cristo

distância entre os dedos

distância entre os dedos da pata direita

distância entre os dedos da pata esquerda

distância entre os dedos da pata no lado não operado

distância entre os dedos da pata no lado operado

distância entre os dedos intermediários

distância entre os dedos intermediários da pata direita 
DIE

DIN

DIO

Dmd

Dmp

FGF

GAGS

GDNF

IFC

IFC1

IFC2

IGF

IAD

IRE

LATM1

LATM2

LATN1

LATN2

MAG

ME

MP distância entre os dedos intermediários da pata esquerda

distância entre os dedos intermediários da pata no lado não

operado

distância entre os dedos intermediários da pata no lado operado

média dos valores dos diâmetros dos axônios no segmento

distal à região do reparo

média dos valores dos diâmetros dos axônios no segmento

proximal à região do reparo

"fibroblast growth factor"

glicosaminoglicanas

"glial cell line-derived neurotrophic factor"

índice funcional ciático

índice funcional ciático na fase pré-operatória

índice funcional ciático na fase pós-operatória

"insulin-like growth factor"

índice de alteração do diâmetro

índice de regeneração dos axônios extrafasciculares

latência do potencial de ação motor pré-operatório

latência do potencial de ação motor pós-operatório

latência do potencial de ação do nervo pré-operatório

latência do potencial de ação do nervo pós-operatório

glicoproteína associada à mielina

matriz extracelular

metaloproteinase 
N-CAM

NGF

NT

PAFU

PAM

PAM1

PAM2

PAN

PAN1

PAN2

PGF

PMP 22

$\%$ AMPM

\%AMPN

$\% \mathrm{VCM}$

$\% \mathrm{VCN}$

$\mathrm{P}_{0}$

SNP

TGF- $\beta$

Trk molécula de adesão celular neural

"nerve growth factor"

neurotrofina

potenciais de ação de fibras únicas

potencial de ação motor

potencial de ação motor pré-operatório

potencial de ação motor pós-operatório

potencial de ação do nervo

potencial de ação do nervo pré-operatório

potencial de ação do nervo pós-operatório

"platelet-derived growth factor"

proteína mielínica periférica 22

porcentagem da amplitude do potencial de ação motor pós-

operatório em relação ao valor pré-operatório

porcentagem da amplitude do potencial de ação do nervo pós-

operatório em relação ao valor pré-operatório

porcentagem da velocidade de condução do potencial de ação

motor pós-operatório em relação ao valor pré-operatório

porcentagem da velocidade de condução do potencial de ação

do nervo pós-operatório em relação ao valor pré-operatório

proteína $\mathrm{P}_{0}$

sistema nervoso periférico

"transforming growth factor- $\beta$ "

"tropomyosin receptor kinase" 
VC

VCM1

VCM2

VCN1

VCN2 velocidade de condução

velocidade de condução do potencial da ação motor pré-

operatório

velocidade de condução do potencial da ação motor pós-

operatório

velocidade de condução do potencial da ação do nervo préoperatório

velocidade de condução do potencial da ação do nervo pós-

operatório 


\section{LISTA DE FIGURAS}

Figura 1 - Corte histológico do nervo ciático do rato. A - estrutura monofascicular. B - estrutura bifascicular.

Figura 2 - Distribuição temporal dos procedimentos do estudo

Figura 3 - Animal que imprime as patas traseiras no corredor utilizado para obtenção dos parâmetros do índice funcional ciático

Figura 4 - Marca da pata traseira esquerda do rato com os parâmetros utilizados na avaliação do índice funcional ciático na fase pré-operatória.

Figura 5 - Exposição cirúrgica do nervo ciático direito do rato.

Figura 6 - Eletrodos do tipo terra

Figura 7 - Foto cirúrgica que mostra a instalação dos eletrodos do tipo terra.....

Figura 8 - Foto cirúrgica que mostra o posicionamento dos eletrodos para a mensuração do potencial de ação do nervo.

Figura 9 - Foto cirúrgica que evidencia o posicionamento dos eletrodos para a avaliação do potencial de ação motor.

Figura 10 - Foto cirúrgica realizada após a secção do nervo ciático

Figura 11 - Foto da pata direita de animal com lesão secundária à autotomia....

Figura 12 - Foto da pata direita de animal que mostra postura secundária à retração músculo-tendínea.

Figura 13 - Reparo com a sutura convencional. A - esquema que mostra o posicionamento dos pontos. $\mathrm{B}$ - foto microcirúrgica que evidencia o reparo com sutura do nervo ciático.

Figura 14 - Reparo com o adesivo. A - esquema que evidencia a aplicação do adesivo. B - foto microcirúrgica que mostra o reparo com adesivo.

Figura 15 - Reparo com a combinação das duas técnicas. A - esquema que evidencia a aplicação do adesivo de fibrina e o ponto de náilon. $\mathrm{B}$ - foto microcirúrgica que demonstra o ponto único do reparo

Figura 16 - Fotografia da região dorso-lateral do animal operado que mostra a proteção utilizada na pata operada para evitar a autotomia. 
Figura 17 - Marcas das patas com os parâmetros utilizados no cálculo do índice funcional ciático pós-operatório. A - marca da pata traseira não operada. B - marca da pata traseira operada.

Figura 18 - Foto cirúrgica que evidencia a instilação do fixador de Karnovsky sobre o nervo ciático previamente operado

Figura 19 - Parâmetros para obtenção dos segmentos proximal e distal do nervo. A - esquema com as distâncias dos locais de secção dos segmentos proximal e distal em relação à região do reparo. B - fotografia do segmento distal.

Figura 20 - Fotomicrografia de região de corte histológico do nervo ciático contendo axônios parcialmente marcados durante o processo de contagem

Figura 21 - Fotomicrografia de região de corte histológico do nervo ciático contendo axônios parcialmente preenchidos durante o processo de mensuração dos perímetros 


\section{LISTA DE SÍMBOLOS}

$\begin{array}{ll}\alpha & \text { alfa } \\ \beta & \text { beta } \\ \mathrm{cm} & \text { centímetro } \\ \mathrm{G} & \text { gauge } \\ \mathrm{gr} & \text { grama } \\ \mathrm{m} / \mathrm{s} & \text { metros por segundo } \\ \mu \mathrm{m} & \text { micrômetro } \\ \mathrm{mA} & \text { miliampère } \\ \mathrm{mg} & \text { miligrama } \\ \mathrm{ml} & \text { mililitro } \\ \mathrm{mm} & \text { milímetro } \\ \mathrm{ms} & \text { milissegundo } \\ \mathrm{mV} & \text { milivolt } \\ \pi & \text { Pi }\end{array}$




\section{LISTA DE TABELAS}

Tabela 1 - Classificação das fibras nervosas de acordo com o diâmetro, velocidade de condução e função

Tabela 2 - Parâmetros obtidos na avaliação do potencial de ação do nervo nos estudos experimentais da literatura que avaliam a eficácia do adesivo de fibrina para o reparo de nervo

Tabela 3 - Resultados da avaliação dos parâmetros do potencial de ação motor em dois estudos experimentais da literatura que avaliam a eficácia do adesivo de fibrina para o reparo de nervo.

Tabela 4 - Número de animais de acordo com a evolução apresentada nos três grupos de reparo 


\section{RESUMO}

Martins RS. Avaliação da eficácia do reparo na regeneração do nervo ciático do rato com utilização de sutura, adesivo de fibrina ou combinação das duas técnicas [tese]. São Paulo: Faculdade de Medicina, Universidade de São Paulo; 2004. 186 p.

Nas lesões onde há secção de nervos o cirurgião necessita restabelecer a continuidade entre dois cotos. Apesar de ser considerado como o método padrão, a sutura com fios de náilon pode ocasionar reação inflamatória prejudicando o processo de regeneração ou ser de difícil execução, nos casos de nervos de calibres reduzidos. O reparo com adesivo de fibrina é uma opção ao reparo com sutura convencional, mas a comparação entre esses dois métodos apresenta resultados conflitantes na literatura. O objetivo deste trabalho foi comparar os parâmetros usualmente empregados na avaliação da regeneração do nervo ciático do rato previamente seccionado com a utilização do reparo com a sutura convencional, com o adesivo de fibrina ou uma combinação das duas técnicas. Previamente à secção do nervo ciático do lado direito, cada animal foi submetido à mensuração do índice funcional ciático a partir de medidas obtidas da impressão das patas traseiras durante a marcha. Após a exposição cirúrgica procedeu-se à avaliação eletrofisiológica que consistia na mensuração da latência, amplitude e velocidade de condução do potencial de ação do nervo e do potencial de ação motor. Com técnica microcirúrgica, os nervos foram seccionados e reparados de forma imediata. Três grupos com 10 animais cada foram formados de acordo com o reparo utilizado. No grupo A, o reparo foi realizado com a sutura utilizando-se quatro pontos de fio de náilon 10-0; no grupo $\mathrm{B}$ a coaptação dos cotos do nervo foi realizada com a aplicação do adesivo de fibrina; no grupo $\mathrm{C}$ o reparo foi realizado com um ponto de náilon 100 associado com a aplicação do adesivo de fibrina. Após 12 semanas o índice funcional ciático foi avaliado nos três grupos e a avaliação funcional da regeneração foi obtida comparando-se os valores deste índice. Após 24 semanas os animais foram reoperados para avaliação eletrofisiológica com as medidas dos mesmos parâmetros que foram avaliados antes da secção do nervo. A avaliação eletrofisiológica da regeneração comparou os valores da amplitude, latência e velocidade de condução dos potencias de ação do nervo e motor, os valores da razão entre a velocidade de condução na reoperação e a velocidade de condução antes da secção do nervo para os dois potenciais e a razão entre a amplitude na reoperação e a amplitude antes da secção dos nervos dos dois potenciais. Após esta avaliação, os nervos foram fixados e retirados para a obtenção de segmentos proximais e distais à região do reparo com a finalidade de se proceder ao estudo histomorfométrico com contagem total dos axônios regenerados, mensuração dos diâmetros desses axônios nesses segmentos e quantificação do número de axônios regenerados em situação extrafascicular no segmento distal. A análise estatística foi realizada através de comparação dos parâmetros obtidos entre os grupos com a análise de variância ou com o teste de Kruskal-Wallis. Quando era identificada uma diferença significativa entre os grupos, para $\mathrm{p}<0,05$, foi utilizado um teste de comparações múltiplas através do método de Tukey ou Duncan. Após 12 semanas do reparo os resultados do índice funcional ciático no grupo B foram superiores aos do grupo A. Não houve diferença significativa na avaliação desse parâmetro entre os grupos B e C. Os animais do grupo B apresentaram melhores resultados na regeneração em comparação com o 
grupo A quando avaliados a latência, a velocidade de condução após o período de observação e a razão entre a velocidade de condução realizada na reoperação e o mesmo parâmetro obtido antes da secção do nervo durante a mensuração do potencial de ação motor. Os animais do grupo $\mathrm{C}$ apresentaram melhores resultados na regeneração em comparação com o grupo A quando avaliada a razão entre a velocidade de condução realizada na reoperação e o mesmo parâmetro obtido antes da secção do nervo na mensuração do potencial de ação motor. Não houve diferença na regeneração avaliada pelo estudo eletrofisiológico entre os grupos B e C. Não houve diferenças significativas na avaliação histomorfométrica entre os três grupos. Considerando os resultados conclui-se que o reparo com o adesivo de fibrina forneceu as melhores condições para a regeneração em comparação com a sutura. 


\section{SUMMARY}

Martins RS. Assessment of the efficacy of regeneration in rat sciatic nerve repair using suture, fibrin glue or a combination of both techniques. [thesis]. São Paulo: "Faculdade de Medicina, Universidade de São Paulo"; 2004. 186 p.

Injuries involving nerves section require the surgeon to reestablish the continuity between the two stumps. Although direct suturing of the nerve using Nylon is considered a standard procedure, it can cause inflammatory reaction impairing the regeneration, or the procedure can be difficult due to reduced nerve caliber. The repair with fibrin glue is an alternative to the conventional suture technique, but comparison between these two techniques have presented conflicting results in the literature. The objective of this study was to compare the parameters commonly applied in assesssing the regeneration of the sectioned rat sciatic nerve, using conventional suture, fibrin glue and a combination of both techniques. Before sectioning the right sciatic nerve, the sciatic functional index of each rat was determined by measuring the printing of the posterior limbs during gait. After the surgical exposure, the electrophysiologic evaluation was performed. It consisted of measuring the latency, magnitude and conduction velocity of the nerve and muscular action potentials. Using the microsurgical techniques, the nerves were sectioned at middle and repaired immediately. Thirty rats were divided evenly into three groups accordingly to the nerve repair technique. In group A, the nerve was repaired with four-stitch suture using Nylon 10-0; in group B the stumps were united using fibrin glue; in group $\mathrm{C}$, the nerve was repaired with a single-stitch suture using Nylon 10-0 and fibrin glue. After 12 weeks, the sciatic functional index of the three groups was evaluated. The functional evaluation of the nerve regeneration was obtained by comparing the sciatic functional index of the three groups. After 24 weeks, the rats underwent reoperation for electrophysiologic assessment based on the same parameters used before the nerve section. The electrophysiologic evaluation of the nerve regeneration consisted of comparing the results of the same parameters evaluated in the first surgery, the ratio between the conduction velocity of the action potential at the reoperation and the same velocity before the division of the nerve and the ratio between the magnitude of the action potential at the reoperation and before the nerve section. After electrophysiologic evaluation, the nerves were fixed and removed to obtain the proximal and the distal stumps for histomorphometric study. The histomorphometric study consisted of total count of regenerated axons, measurement of the regenerated axons diameter in both stumps, and the determination of the number of the regenerated axons in extrafascicular location in the distal stump. Statistical analysis was performed by comparing the parameters obtained from the three groups using ANOVA or the Kruskal-Wallis test. Whenever a significant difference between the groups was identified, with $\mathrm{p}<0.05$, a multiple comparison test (Tukey or Duncan) was applied. With regards to the sciatic functional index 12 weeks after the repair, the rats of group B presented better outcome than those of group A. There was no significant difference between groups $\mathrm{B}$ and $\mathrm{C}$. When latency and the nerve conduction velocity assessed at the reoperation, and the ratio between the conduction velocity at the reoperation and before the nerve division in the motor action potential evaluation were measured, the rats of group B presented better results in regeneration than those of group A. As for regeneration, 
with the motor action potential evaluation, rats of group $\mathrm{C}$ presented better results than those of group A when the ratio between the nerve conduction velocity at the reoperation and before the nerve division was considered. No difference between groups $\mathrm{B}$ and $\mathrm{C}$ was found in regeneration evaluated by means of electrophysiologic study. There were no significant differences in regard to the histomorphometric evaluation between the three groups. Based on the results, we conclude that nerve repair using fibrin glue provided the best conditions for regeneration than the suture. 
1. INTRODUÇÃO 


\section{INTRODUÇÃO}

O método cirúrgico mais adequado visando ao reparo de lesões onde houve secção de um nervo é a sutura epineural término-terminal ${ }^{1}$. Sua realização, no entanto, pode apresentar dificuldades técnicas durante o posicionamento dos pontos e ocasionar um processo inflamatório exuberante, acarretando desorganização de fibras nervosas no processo de regeneração.

$\mathrm{Na}$ tentativa de minimizar essas dificuldades e efeitos, Young e Medawar ${ }^{2}$ desenvolveram, na década de 40, um método de reparo experimental no qual as superfícies transversas do nervo eram coaptadas através da utilização de cola biológica derivada do plasma sangüíneo de galos. Embora esses autores tenham considerado o método superior à sutura tradicional, na mesma época Tarlov e Benjamin $^{3}$, utilizando metodologia semelhante, observaram reação inflamatória e fibrose mais exuberantes com o adesivo biológico em comparação com o processo inflamatório identificado na utilização da sutura com fio de seda.

A despeito da publicação de Sedon e Medawar ${ }^{4}$ demonstrando resultados clínicos satisfatórios com o uso da cola biológica, as dificuldades técnicas envolvidas na obtenção de um adesivo a partir do plasma humano e o posterior desenvolvimento da microcirurgia após a década de 60, fizeram com que a utilização da sutura persistisse como método preferencial no reparo das lesões de nervos.

Em 1970 um novo adesivo tecidual foi desenvolvido a partir de solução de fibrinogênio humano, mais pura, concentrada e associada ao fator XIII, que torna a fibrina insolúvel e, desta forma, estável e mais resistente. O emprego desse novo tipo de adesivo tecidual propiciava redução do tempo cirúrgico, simplificação da técnica, 
menor trauma tecidual e reação inflamatória menos intensa. Apesar dessas vantagens teóricas, a utilização de adesivos no tratamento de lesões de nervos apresenta resultados contraditórios na literatura consultada ${ }^{5,6,7,8,9,10,11,12, ~ 13, ~ 14, ~ 15, ~ 16, ~ 17, ~ 18, ~ 19, ~ 20, ~}$ $21,22,23,24,25,26,27,28,29,30$

O presente estudo experimental visa estabelecer o método que propicia as melhores condições para a regeneração após a secção completa e o reparo de nervos ciáticos de ratos. Para tal utilizou-se três técnicas distintas, cada uma aplicada a 10 ratos machos Wistar. Para a avaliação da regeneração entre os três grupos foram comparados os parâmetros obtidos das avaliações funcional, eletrofisiológica e histomorfométrica. 


\section{REVISÃO DA LITERATURA}




\section{REVISÃO DA LITERATURA}

\subsection{Embriologia do Nervo}

Os primeiros eventos que originarão o sistema nervoso central e o sistema nervoso periférico ocorrem em torno do décimo oitavo dia de desenvolvimento. $\mathrm{Na}$ região médio-dorsal do embrião a ectoderme se espessa formando uma placa alongada denominada placa neural. As bordas laterais desta placa elevam-se constituindo as pregas neurais e determinam um sulco, o sulco neural ${ }^{31}$. No período entre a nona e a décima semana as pregas neurais se fundem formando o tubo neural. A parede do mesmo é constituída por um único tipo de célula denominada neuroepitelial e organizada em um epitélio pseudoestratificado ${ }^{31}$. Entre a oitava e a vigésima segunda semana, parte das células neuroepiteliais perde a capacidade de se dividir e se diferencia em uma célula chamada neuroblasto. $\mathrm{O}$ neuroblasto inicialmente é uma célula apolar que rapidamente desenvolve dois processos citoplasmáticos opostos tornando-se uma célula bipolar ${ }^{32}$. Um desses se alonga formando o axônio, que se desenvolve e se exterioriza da medula espinhal na forma de feixes que são inicialmente envolvidos por duas camadas celulares. A camada interna é constituída por precursores de origem mesenquimal e que formarão os elementos relacionados ao tecido conjuntivo de um nervo. A camada externa é constituída de células de Schwann (CS), descritas por Theodore Schwann em 1839*, citado por Aszman ${ }^{33}$. Essas células se proliferam, atravessam a camada de células mesenquimais e se localizam entre os grupos de axônios. Esse processo se inicia por 
volta do décimo segundo dia de vida embrionário no rato e no camundongo e na décima segunda semana nos nervos do plexo braquial e no nervo ciático humanos ${ }^{34}$.

As CS são originadas da migração e diferenciação de células constituintes da crista neural e são responsáveis pelo processo de mielinização ${ }^{35}$. As células da crista neural constituem uma população mista de células em vários estágios de diferenciação. Durante o desenvolvimento, alterações fenotípicas progressivas ocorrem nas CS que se diferenciam de células da crista neural para células precursoras das CS, CS imaturas, até que essas células atinjam a morfologia das CS adultas $^{36}$. As células precursoras das CS se formam entre o décimo quarto e o décimo quinto dia de vida embrionária no rato e as CS imaturas no período entre o décimo sétimo dia de vida embrionária até o momento do nascimento ${ }^{36}$. Na época do nascimento as células imaturas dividem-se em dois grupos, as CS mielinizantes e as CS não mielinizantes.

Na décima quarta semana de vida do embrião humano, as CS estão distribuídas uniformemente em torno de grupos de axônios e envolvem, através de invaginações das membranas dessas células, centenas de axônios ${ }^{37,38}$. Como resultado de divisões celulares repetidas estabelece-se rapidamente a relação de um para um entre as CS mielinizantes e as fibras nervosas de maior diâmetro ${ }^{38,39}$. As CS não mielinizantes acompanham as fibras de menor diâmetro ${ }^{35}$. Esse processo, que também ocorre durante a regeneração, é determinado pela ação de vários fatores de transcrição expressos pela ação de certos genes tais como Sox-10, Krox-20 ou Egr-2 e genes da classe "homeobox" como o Oct-6 ou SCIP ${ }^{40}$. O fator de transcrição Sox-10 começa a ser expresso nas primeiras células da crista neural que iniciam a migração. Supõe-se que esse fator esteja envolvido no processo de formação das células da glia e na via 
metabólica de síntese da proteína $\mathrm{P}_{0}\left(\mathrm{P}_{0}\right)^{41,42}$. Os fatores de transcrição Oct-6 e Krox20 estão relacionados ao processo de mielinização $0^{40,42}$. Evidências sugerem que a função principal do gene regulatório Krox-20 é a supressão da expressão da via celular da proteína c-Jun, cuja ativação inibe o processo de mielinização das CS e influencia a resposta dessas células ao "transforming growth factor- $\beta$ " (TGF- $\beta$ ), um fator neurotrófico implicado na manutenção da integridade das mesmas ${ }^{40}$. Fatores de transcrição relacionados à manutenção e diferenciação das CS como Krox-24, Pax3 e c-Jun também são expressos nesta fase ${ }^{40,41,43}$. Evidências sugerem que o momento da interrupção das divisões celulares das CS coincide temporalmente com a constituição da membrana basal em torno dessas células ${ }^{44}$.

As células precursoras das CS podem ser diferenciadas das células em migração da crista neural pela interação com a beta neuroregulina e pela presença de três marcadores, a $\mathrm{P}_{0}$, a proteína 43 e a CD9 ${ }^{45}$. A transição das células precursoras para as CS é caracterizada por alterações na expressão de proteínas e lipídios e inclui a expressão da proteína S-100. Evidências de estudos in vitro e in vivo definiram que a molécula principal envolvida na manutenção das células precursoras das CS e na sua diferenciação até células maduras é a beta-neuroregulina, produzida pelos axônios em desenvolvimento e que atua em receptores específicos denominados ErbB2 e ErbB3 ${ }^{35}$, 36. Estudos experimentais realizados in vitro e in vivo demonstraram que há também a participação de fatores neurotróficos como o "fibroblast growth factor" (FGF) e as endotelinas na regulação do processo de maturação das $\mathrm{CS}^{42,45}$. Esses fatores atuam na determinação da quantidade de células que se diferenciarão e na duração do processo de maturação ${ }^{35}$. 
Evidências sugerem que as células precursoras das CS produzem substâncias relacionadas à manutenção da sua própria sobrevida ${ }^{35}$, 46 . Entre essas, podem ser destacados o "insulin-like growth factor" (IGF), o "platelet-derived growth factor" (PGF) e a neurotrofina (NT) 3.

Estudos recentes têm demonstrado que componentes da matriz extracelular (ME) também participam do desenvolvimento das CS. Esses componentes, em contato com as células constituintes da crista neural, atuam na promoção do processo de migração dessas células para formar as $\mathrm{CS}^{47}$. As integrinas, moléculas relacionadas à adesão celular, presentes na superfície das CS, também são fundamentais nesse processo ${ }^{47}$. Vários receptores para integrinas tais como a beta 1 , beta 3 e beta 5 integrinas, foram descritos nas células da crista neural. A inibição desses receptores bloqueia a migração das células da crista neural em estudos in vitro e in vivo ${ }^{47,48}$.

As CS atuam no desenvolvimento do nervo não só sobre as estruturas neurais, mas também sobre a formação do epineuro ${ }^{35}$. Estudos experimentais demonstraram que uma molécula secretada pelas CS denominada "desert hedgehog", um membro da família de moléculas sinalizadoras "hedgehog", está envolvida na formação do tecido conjuntivo do epineuro, endoneuro e perineuro ${ }^{49,50}$. Essas moléculas se ligam a receptores específicos das células mesenquimais denominados "patched" iniciando o processo de recrutamento destas células para a formação dessas estruturas. Em animais onde o gene responsável pela produção de "desert hedgehog" é reprimido, o perineuro é anormalmente fino, as junções estreitas das células perineurais são anormais e imaturas e a membrana basal é descontínua, resultando em perda da função da barreira tecidual que caracteriza o nervo normal ${ }^{42}$. O colágeno no epineuro 
é escasso e, em algumas regiões, ausente ${ }^{42}$. Ao contrário dos fibroblastos presentes no endoneuro normal, nesses animais essas células apresentam-se organizadas de forma mais esparsa e a membrana basal nesse local é descontínua e apresenta espessura reduzida ${ }^{35}$.

Da mesma forma que o axônio controla importantes etapas no desenvolvimento das CS, substâncias liberadas por essas células atuam sobre os axônios mielinizados regulando o seu número e calibre, a distribuição dos canais iônicos e influenciando o metabolismo dos neurofilamentos ${ }^{35}$.

Resultados de recentes estudos sugerem que a formação do nódulo de Ranvier é regulada pela ação das $\mathrm{CS}^{36,51}$. A membrana axonal na região do nódulo apresenta uma especialização molecular complexa caracterizada principalmente pela presença de numerosos canais de sódio. Nas CS situadas na região do nódulo de Ranvier ${ }^{36,51}$, durante formação do mesmo, há um aumento dos níveis de ácido ribonucléico mensageiro correspondente à produção de subunidades dos canais de sódio.

Nas fibras nervosas humanas a formação da bainha de mielina tem início ao redor do quarto mês de vida fetal e está associada com a interrupção das divisões celulares das $\mathrm{CS}^{52}$. O processo de mielinização se continua durante todo o primeiro ano de vida pós-natal. A alta demanda por proteínas relacionadas à formação da mielina durante o desenvolvimento e a regeneração do nervo é acompanhada pela expressão coordenada de genes que as codificam, como os relacionados à produção da $\mathrm{P}_{0}$, da proteína proteolipídica, da periaxina, da proteína mielínica periférica 22 (PMP 22) e da glicoproteína associada à mielina (MAG). Estudos experimentais sugerem que as integrinas presentes na superfície das CS, especialmente os 
receptores para laminina alfa6beta1 e alfa6beta4, são importantes no processo de mielinização durante o desenvolvimento ${ }^{53}$.

A gênese dos nervos está diretamente relacionada com a constituição da medula espinhal. Durante a formação do sistema nervoso, na região da medula espinhal, as paredes do tubo neural originam espessamentos ventrais e dorsais, contendo células de características fenotípicas distintas e que originarão os neurônios motores e sensitivos. Essa organização distinta resulta da integração de sinais extrínsecos e intrínsecos que controlam a proliferação e a diferenciação desses subtipos celulares. Proteínas da classe "hedgehog" e proteínas ósseas morfogenéticas participam do processo inicial de diferenciação celular na medula em formação, que é complementado pela atuação de fatores de transcrição regulatórios como as proteínas da classe "homeodomain" e "basic helix-loop-helix factors" 54.

Os espessamentos ventrais do tubo neural originarão as placas basais, formadoras das futuras áreas motoras do neuroeixo. Os espessamentos dorsais originarão as placas alares, formadoras das futuras áreas sensoriais da medula. As placas alares se desenvolvem e aproximam-se uma da outra na linha média, obliterando a porção dorsal do tubo neural e constituindo os cornos dorsais da medula. As placas basais se expandem direcionando-se ventralmente e formam os cornos ventrais da medula. Os axônios dos neurônios do corno basal serão predominantemente eferentes e, após atravessarem a substância branca medular, saem da medula constituindo a raiz motora dos nervos espinhais ${ }^{55}$.

A formação dos gânglios espinhais se inicia durante o fechamento do tubo neural. Nesse período algumas células localizadas próximas à borda dessa estrutura se isolam, constituindo uma lâmina dorsal contínua ${ }^{56}$. Essa lâmina se divide 
formando duas colunas contínuas chamadas cristas neurais, paralelas à placa neural, estendendo-se da extremidade caudal até a região do mesencéfalo do tubo neural. Essas estruturas sofrem um processo de segmentação formando blocos que se situam no mesmo nível dos somitos. Nesses blocos as células da crista neural irão constituir os neurônios dos gânglios espinhais, do tipo pseudo-unipolar. Nas primeiras semanas de desenvolvimento do embrião, os axônios destas células invadem a medula e constituem as raízes dorsais. Os prolongamentos centrífugos desses neurônios inervarão os órgãos receptores sensitivos ${ }^{57}$.

A união da raiz motora e sensitiva irá constituir os nervos ${ }^{56}$ que acompanham o tecido muscular em formação durante o desenvolvimento. O mecanismo de crescimento axonal para a formação dos nervos durante a embriogênese é semelhante ao que ocorre durante a regeneração e é possível através da interação entre receptores de superfície do cone de crescimento, componentes específicos da matriz extracelular e proteínas das membranas das células em diferenciação ${ }^{53}$. Evidências experimentais sugerem que o cone de crescimento desses axônios está programado para seguir uma via específica de migração ${ }^{58}$. Essa especificidade é determinada pela atuação de moléculas de adesão celulares (CAM). Nos vertebrados a principal molécula que atua nessa interação é a molécula de adesão celular neural (N-CAM) e outras proteínas difusíveis secretadas pelo próprio neurônio em desenvolvimento. As neutrinas são uma classe dessas proteínas que interagem com receptores do cone de crescimento denominados UNC, produtos de genes específicos como o unc-5, unc-6 e o unc- $40^{59}$.

Nos membros, o desenvolvimento dos nervos está intimamente relacionado à formação dos somitos. Os músculos estriados do tronco e membros originam-se 
dessas estruturas que, por volta do vigésimo dia de vida embrionária das aves, estão distribuídas aos pares após a segmentação da mesoderme ${ }^{60}$. Logo após a sua constituição, o somito se divide em três subdivisões denominadas esclerótomo, miótomo e dermátomo. As células derivadas dessas estruturas originarão os tecidos esquelético, muscular e a derme, respectivamente ${ }^{61}$. No momento em que se inicia o desenvolvimento dos somitos, os ramos dos nervos já acompanham essas estruturas em direção aos membros. Após a sua constituição, o miótomo se alarga e divide-se numa porção dorsal situada lateral ao tubo neural, o epímero, e em uma porção ventral maior denominada hipômero. Os epímeros sofrem poucas modificações e originam os músculos extensores da coluna vertebral ${ }^{62}$. Durante essa fase do desenvolvimento os ramos dorsais dos nervos que inervam os miótomos acompanham os epímeros e os ramos ventrais acompanham os hipômeros, que originarão os músculos abdominais e parte dos músculos da região cervical.

O processo de formação dos membros se inicia a partir da quarta semana de vida embrionária no homem. Os membros se formam na região lateral do embrião a partir de brotos resultantes de alterações bioquímicas celulares que ocorrem com a expressão de produtos de genes específicos, levando a proliferação e a migração de determinado grupo de célula. Os principais produtos que possibilitam esse processo são o ácido retinóico, o TGF- $\beta$, o FGF e as moléculas da classe "hedgehog"63. Durante a quinta semana de vida embrionária ocorre uma migração das células dos miótomos, denominadas mioblastos, que invadem o broto do membro em formação. Durante esse evento, essas células se diferenciam em fibras musculares que constituem os músculos dos membros e são acompanhadas pelos ramos ventrais dos nervos espinhais ${ }^{64}$. Esse fato possibilita a contração desses músculos a partir da 
oitava semana de vida embrionária ${ }^{61}$. Nesta fase, os plexos braquial e lombossacral e os grandes troncos dos nervos já estão formados ${ }^{63}$. Parte dos ramos dos nervos também acompanha a derme em formação e, por volta da sétima semana de vida embrionária, esses ramos estão distribuídos nos dermátomos correspondentes de forma semelhante à identificada no indivíduo adulto ${ }^{63}$.

\subsection{Histologia do Nervo}

A palavra nervo é derivada do Latim nervus e significa tendão. Segundo Sunderland, a identificação do nervo como uma estrutura distinta dos tendões foi estabelecida por Herophilus no terceiro século antes de Cristo (a.C.), que também descreveu a relação dos mesmos com a medula espinhal e identificou seus componentes sensitivos e motores ${ }^{65}$.

O termo fascículo neural origina-se do Latim fascis que significa feixe e é utilizado para descrever um grupo de fibras nervosas em associação com elementos não neurais, limitados por uma camada externa formada por tecidos epitelial e conjuntivo denominada perineuro. Aproximadamente 40 a $50 \%$ do fascículo é ocupado por fibroblastos, fluído endoneural e tecido conjuntivo, detectando-se, ocasionalmente, macrófagos e mastócitos ${ }^{66}$. O nervo pode ser monofascicular, quando constituído por um só fascículo, ou polifascicular, quando é formado por dois ou mais fascículos ${ }^{65}$ (Figura 1 A e B). No homem, os fascículos dividem-se repetidamente em ramos formando uma trama que possui uma organização peculiar 
variando de indivíduo para indivíduo, nervo para nervo e de acordo com a sua localização topográfica e lateralidade ${ }^{67,68}$.
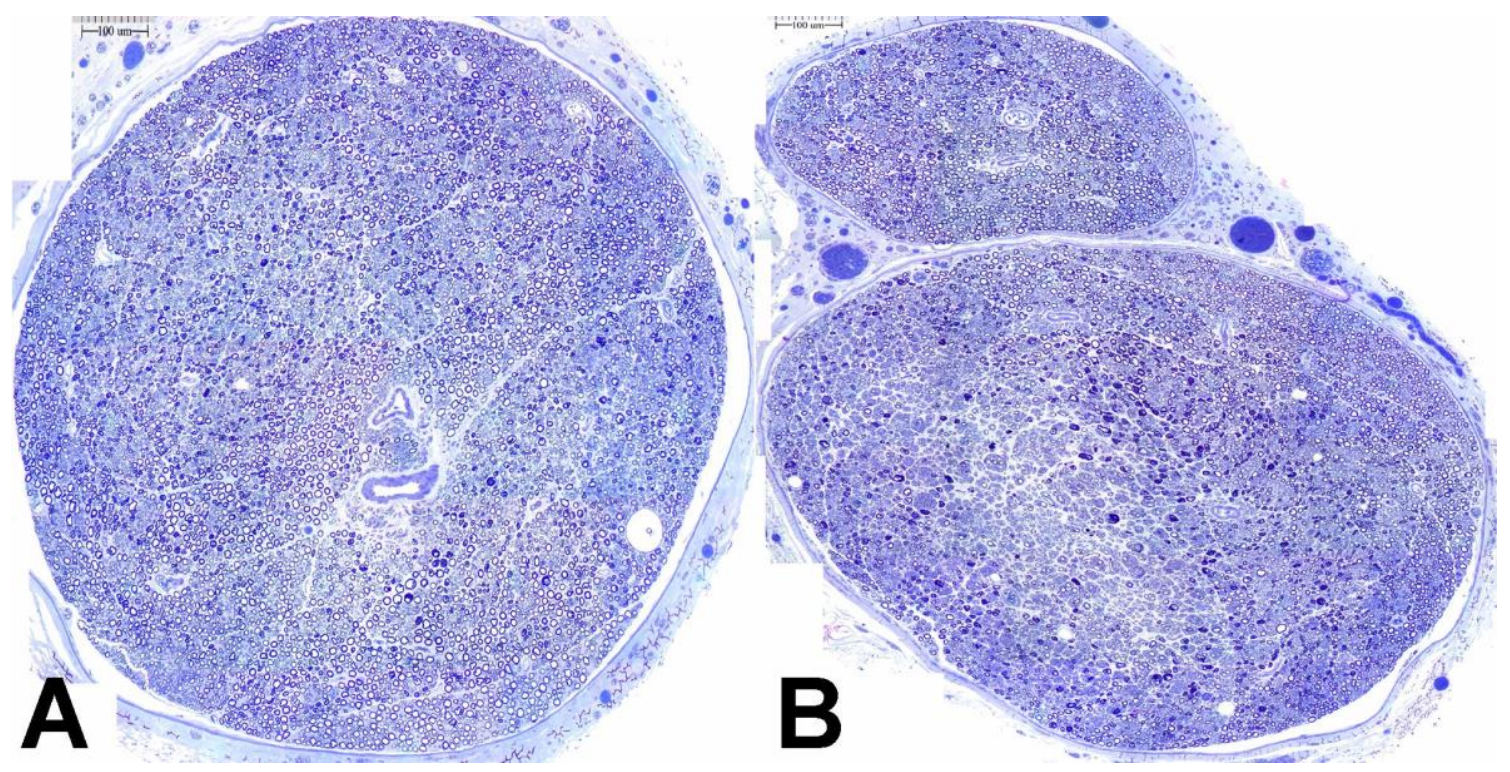

Figura $1-\mathrm{A}$ : Fotomicrografia obtida de corte axial do nervo ciático do rato que evidencia organização monofascicular; coloração azul de toluidina a $1 \%$. B: Fotomicrografia obtida de corte axial do nervo ciático do rato que mostra organização bifascicular; coloração azul de toluidina a $1 \%$.

A unidade condutora do nervo é a fibra nervosa, constituída na região central pelo axônio envolvido por uma camada única de CS que se dispõem em série e interligadas ao longo do axônio. Paetau et al descrevem que externamente à célula de Schwann há uma membrana basal, um estrato organizado de macromoléculas da ME que forma uma camada de suporte tubular contínua, constituída predominantemente por colágeno do tipo IV e que contém ainda laminina e fibronectina ${ }^{69}$. Na fibra nervosa o axônio e a célula de Schwann estão intimamente relacionados de forma que não há ME entre essas estruturas.

A membrana celular das CS apresenta uma variedade de canais iônicos, especialmente canais de potássio. A função desses canais ainda não foi bem estabelecida, mas, com relação aos canais de potássio, sugere-se que atuem 
mantendo o potencial de repouso através do controle da concentração externa desse ín $^{70}$.

O colágeno do tipo IV é identificado exclusivamente na membrana basal e é caracterizado por formar uma rede bidimensional ${ }^{71}$. A laminina é o segundo componente em quantidade presente na membrana basal, após o colágeno tipo IV. A laminina é uma proteína que apresenta vários sítios de ligação com outros constituintes da membrana basal, incluindo o colágeno do tipo IV e as CAM como as integrinas $^{72}$. A laminina é constituída por três unidades denominadas de cadeias alfa, beta e gama que se combinam resultando na formação de diferentes isoformas desta molécula. A isoforma denominada de lamina-2 ou merosina é a identificada na membrana basal das CS e é diferente da isoforma isolada na membrana basal do perineuro $^{47}$. As fibronectinas são proteínas de cadeias longas que atuam promovendo a adesão entre o colágeno, determinados componentes da ME e integrinas presentes na superfície celular ${ }^{72,73}$.

O colágeno é a maior proteína insolúvel presente na ME e esta distribuição se mantém no nervo. Todos os 16 tipos de colágeno descritos no organismo humano apresentam uma seqüência repetida de aminoácidos representados pela glicina, prolina e hidroxiprolina, organizados em uma estrutura característica em forma de tripla hélice ${ }^{73}$. Os vários tipos de colágeno são distinguíveis pelo tipo de organização de suas fibras, constituídas a partir da associação de suas regiões helicoidais e não helicoidais. No nervo humano o colágeno predominante é o do tipo I, mas o tipo III e o IV também são identificados ${ }^{74}$.

A maioria do colágeno presente no nervo é produzida por fibroblastos localizados no epineuro ${ }^{74}$. Esta produção de colágeno pelos fibroblastos no nervo é 
mediada pelo TGF- $\beta^{75}$. As CS também participam da produção de colágeno ${ }^{76}$. Evidências experimentais sugerem que a produção de elementos da membrana basal e da ME pelas CS, como o colágeno e a fibronectina, é regulada por interações estabelecidas entre essas células e os neurônios, provavelmente através da intermediação de fatores neurotróficos ${ }^{77}$.

Na fibra nervosa o axônio é constituído pelo citoplasma neuronal, denominado de axoplasma, limitado por uma membrana celular nominada de axolema. A maioria das organelas axoplasmáticas é constituinte do citoesqueleto, que é definido como uma trama formada por três tipos de fibras, os microfilamentos, os filamentos intermediários e os microtúbulos. Os microfilamentos são constituídos por polímeros de actina conectados por ligações com diferentes proteínas e estão relacionados a fenômenos de motilidade celular ${ }^{78}$. Os microtúbulos são polímeros de subunidades globulares de dois tipos de proteínas denominadas tubulinas, a alfa e a beta, organizadas na forma de um tubo cilíndrico de 24 nanômetros de diâmetro. Os microtúbulos estão envolvidos no processo de transporte de organelas e vesículas no axoplasma e são responsáveis por vários movimentos celulares, incluindo a expansão dos cones de crescimento dos axônios em regeneração ${ }^{79}$. No axônio os filamentos intermediários são representados pelos neurofilamentos ${ }^{80}$. Cada neurofilamento é constituído por três tipos de polipeptídeos denominados de NF-L, NF-M e NF-H, de acordo com o seu peso molecular. Os neurofilamentos apresentam-se organizados de forma radial em relação ao maior eixo do axônio. Em contraste com as funções de movimento dos microtúbulos, a função dos neurofilamentos é estritamente estrutural. Esses elementos do citoesqueleto distribuem as forças de tensão exercidas pelos tecidos vizinhos sobre o axônio ${ }^{80}$. 
As fibras nervosas podem ser mielinizadas ou não. Nas mielinizadas, entre cada célula de Schwann ocorre uma constrição livre de mielina que mede cerca de um micrômetro $(\mu \mathrm{m})$ de largura denominada nódulo de Ranvier ${ }^{70}$. Nos axônios de maior diâmetro a distância entre os nódulos é de cerca de um milímetro (mm), correspondendo a extensão longitudinal de uma célula de Schwann e seus processos citoplasmáticos $^{70}$. De acordo com Sunderland e Roche ${ }^{81}$, o diâmetro da fibra nervosa está diretamente relacionado com o diâmetro do axônio, que varia de 0,5 a $15 \mu \mathrm{m}$ nos mamíferos, e da camada de mielina.

A extensão do axônio varia de poucos milímetros a mais de um metro. A bainha de mielina é uma resultante direta da célula de Schwann e sua formação se inicia a partir de um prolongamento do citoplasma dessa célula que repetidamente envolve o axônio, constituindo uma série de lâminas concêntricas de citoplasma ao redor do mesmo ${ }^{70}$. Essas lâminas são subseqüentemente comprimidas formando camadas alternadas de proteínas e lipídios que, sob magnificação, constituem a estrutura laminar característica da bainha de mielina ${ }^{70}$. Essa membrana de mielina apresenta regiões de descontinuidade em forma de canais denominados de incisuras de Schmidt-Lanterman, cuja função ainda é indefinida ${ }^{52,82}$.

O conteúdo protéico da mielina é comparativamente menor em relação aos fosfolipídios, o elemento predominante da sua constituição. A maior parte da proteína presente na mielina no Sistema Nervoso Periférico (SNP) é constituída pela $\mathrm{P}_{0}$ e é sintetizada somente pelas $\mathrm{CS}$. A $\mathrm{P}_{0}$ apresenta duas porções, uma situada no interior de uma camada da bainha de mielina e outra que se exterioriza a partir dessa camada e se relaciona com a porção exoplasmática de uma $\mathrm{P}_{0}$ adjacente. Conseqüentemente, a função principal da $\mathrm{P}_{0}$ é a manutenção da compactação da 
bainha de mielina ${ }^{83}$. A PMP22 forma um complexo com a $\mathrm{P}_{0}$ e contribui para a manutenção da estrutura da mielina ${ }^{70}$.

Nas fibras não mielinizadas o citoplasma de uma célula de Schwann circunda um ou, mais comumente, vários axônios ${ }^{68}$. Freqüentemente toda a superfície do axônio não mielinizado é envolvida pela célula de Schwann. Quando há uma área dessa superfície que não está em contato com essa célula, a membrana basal separa o axônio do endoneuro ${ }^{39,84}$. Essa disposição anatômica propicia um contato importante entre o axônio e as CS e torna a propagação de impulsos mais eficaz através do axônio $^{44,85}$.

O maior componente do nervo é constituído pelo tecido conjuntivo ${ }^{86}$. Esse tecido é formado por duas proteínas, o colágeno e a elastina, e as proteoglicanas, uma família de moléculas híbridas consistindo de proteínas ligadas covalentemente a polissacarídeos. No nervo o constituinte celular do tecido conjuntivo é representado principalmente pelos fibroblastos. Thomas estimou que $45 \%$ dos núcleos identificados em secções transversas do nervo ciático de coelho originam-se dos fibroblastos ${ }^{87}$. Segundo Sunderland e Bradley, a secção transversa de um nervo humano tem cerca de 60 a $85 \%$ de sua área constituída por tecido conjuntivo ${ }^{88}$. Esse tecido, dependendo de sua localização topográfica, pode ser subdividido em epineuro externo, epineuro interno, perineuro e endoneuro. Nervos intactos contêm uma população residente de macrófagos que corresponde a 2 a $9 \%$ do total de células ${ }^{89}$.

O epineuro externo consiste no tecido conjuntivo que envolve e limita o nervo. O epineuro interno, que é uma extensão centrípeta do epineuro externo, delimita os fascículos nervosos. Uma secção transversa mostra que o epineuro interno corresponde a 30 a $75 \%$ da área de um nervo ${ }^{86}$. Histologicamente o epineuro é 
formado por tecido conjuntivo areolar onde se identifica uma rede de fibras de colágeno organizadas frouxamente, sendo detectadas ocasionalmente fibras de elastina $^{84}$. De acordo com Brown et al, $85 \%$ do total de colágeno de um nervo humano está presente no epineuro enquanto que $15 \%$ está situado no endoneuro ${ }^{90}$. No epineuro as fibras de colágeno são orientadas em feixes predominantemente circunferenciais em relação ao maior eixo do nervo e se interlaçam em diferentes direções determinando um padrão irregular, permitindo uma certa extensibilidade e elasticidade do mesmo ${ }^{86}$. Essas fibras possuem um diâmetro que varia de 60 a 110 nanômetros nos troncos nervosos humanos e são mais finas em comparação àquelas presentes no perineuro e endoneuro ${ }^{91}$.

Além dos fibrolastos, o epineuro pode conter mastócitos e uma quantidade variável de tecido gorduroso ${ }^{68}$. De acordo com Sunderland, a gordura seria um fator protetor que atuaria como um coxim contra uma possível compressão dos fascículos $^{86}$. O epineuro contém vasos linfáticos que não estão presentes nos fascículos. Segundo Sunderland, esses pequenos ductos acompanham as artérias dos troncos dos nervos, constituindo uma rede cuja drenagem atinge vasos linfáticos maiores e os nódulos linfáticos regionais ${ }^{92}$.

O perineuro é definido como uma fina camada de células perineurais de origem mesotelial, dispostas em lâminas concêntricas, que circunda um grupo de fibras nervosas. De acordo com Sunderland ${ }^{86}$, o perineuro é constituído por três camadas distintas. A primeira, no sentido centrífugo, é a formada por células mesoteliais uniestratificadas e separada do endoneuro por um espaço denominado subperineural. Nesse espaço identificam-se septos que unem o perineuro ao endoneuro. A segunda camada, denominada intermediária, é constituída por células perineurais organizadas 
em séries de três a 15 lamelas concêntricas, dependendo da espessura do fascículo ${ }^{86}$. Quanto maior o diâmetro do fascículo, maior o número de lamelas ${ }^{87}$. Intercalando essas lamelas identificam-se os processos citoplasmáticos das células perineurais e fibras de colágeno e elastina. As fibras de colágeno se distribuem de maneira a formar uma rede compacta. As células perineurais das camadas intermediária e interna se unem através de junções estreitas que constituem uma barreira à passagem de macromoléculas ${ }^{91}$. A terceira, a camada externa, se mistura com o epineuro e constitui uma transição gradual entre o mesmo e o perineuro, onde as células perineurais são substituídas progressivamente por fibroblastos e as fibras colágenas tornam-se mais finas. Essas células perineurais são consideradas um tipo de fibroblasto especializado ${ }^{68}$. Por causa das propriedades estruturais do perineuro, os fascículos apresentam um aspecto ondulado ao longo do seu maior eixo, disposição que protege o mesmo de possíveis estiramentos ${ }^{93}$.

O tecido conjuntivo que forma a estrutura de suporte para as fibras nervosas e capilares dentro do fascículo é denominado de endoneuro. Os principais elementos constituintes do endoneuro são a membrana basal, a bainha endoneural, os fibroblastos e as fibras de colágeno, a maioria organizada de forma longitudinal e de diâmetro inferior ao das fibras do perineuro ${ }^{68}$. Segundo Junqueira et al, o colágeno III é o tipo principal identificado no endoneuro ${ }^{76}$. O endoneuro em contato com a superfície externa da membrana basal das CS forma uma bainha endoneural que delimita a fibra nervosa. Esta bainha circunscreve um espaço cilíndrico ocupado pelo axônio, CS e mielina, quando esta é presente, denominado de tubo endoneural. Durante as alterações presentes na degeneração walleriana, que incluem a 
desintegração do axônio e da mielina e a remoção de fragmentos celulares, essa coluna de tecidos é representada exclusivamente pelas CS e macrófagos.

O suprimento sangüíneo do nervo é abundante e mantido através de vasos que apresentam um trajeto de sentido longitudinal em relação ao seu maior eixo ${ }^{94}$. Cada artéria nutriente, à medida que se aproxima do nervo, se divide em um ramo ascendente e descendente ${ }^{94}$. Esses vasos atingem os fascículos após um trajeto transversal no epineuro interno ${ }^{95}$. Uma rede colateral possibilita a manutenção de um aporte sangüíneo pela ocorrência de vasos que trafegam através do mesoneuro ${ }^{96}$. Esta estrutura, que contribui para a manutenção da excursão longitudinal do nervo, é formada por tecido conjuntivo areolar que muitas vezes circunda o epineuro e se estende para os tecidos adjacentes ${ }^{97}$. O endotélio dos capilares intrafasciculares impede a passagem de várias substâncias pela presença de junções estreitas entre as células endoteliais. A associação dessas conexões intercelulares com a barreira de difusão de proteínas, presente na membrana perineural, representa uma barreira hemato-neural semelhante à barreira hemato-encefálica e é essencial para a manutenção de um ambiente endoneural especializado na condução de impulsos $\operatorname{nervosos}^{87,95}$.

Fibras nervosas aferentes e eferentes contribuem para a formação do nervo ${ }^{98} . \mathrm{O}$ diâmetro das fibras motoras varia de dois a $20 \mu \mathrm{m}$. As mais calibrosas inervam fibras musculares extrafusais e as mais finas, as fibras musculares intrafusais dos músculos estriados. As fibras sensitivas podem ser mielinizadas ou não. As mielinizadas possuem um diâmetro que varia de 1,5 a $20 \mu \mathrm{m}$. As fibras sensitivas podem terminar livremente na periferia cutânea ou em uma variedade de órgãos terminais especializados. As fibras simpáticas se originam a partir de processos pós- 
ganglionares de neurônios do tronco simpático. Essas fibras não são mielinizadas e inervam vasos, folículos pilosos, músculos e glândulas da pele. De acordo com a associação entre uma região da curva do potencial de ação provocado e o calibre da fibra, três tipos fundamentais de fibras nervosas podem ser identificados: a tipo A, subdividida em alfa, beta, gama ou delta, a tipo B e a tipo C. A tabela 1 sumariza esses três tipos de fibras nervosas classificando-as de acordo com o diâmetro, velocidade de condução (VC) e função ${ }^{98}$

Tabela 1 - Classificação das fibras nervosas de acordo com o diâmetro, velocidade de condução e função.

\begin{tabular}{|c|c|c|c|}
\hline Tipo & Diâmetro & VC $(\mathrm{m} / \mathrm{s})$ & Função \\
\hline \hline A Alfa & $12-20 \mu \mathrm{m}$ & $70-120 \mathrm{~m} / \mathrm{s}$ & $\begin{array}{c}\text { Motora. Fibras musculares extrafusais. } \\
\text { Proprioceptivas. }\end{array}$ \\
\hline A Beta & $5-12 \mu \mathrm{m}$ & $30-70 \mathrm{~m} / \mathrm{s}$ & Tato. Pressão. \\
\hline A Gama & $3-6 \mu \mathrm{m}$ & $15-30 \mathrm{~m} / \mathrm{s}$ & Motora. Fibras musculares intrafusais. \\
\hline A Delta & $2-5 \mu \mathrm{m}$ & $10-30 \mathrm{~m} / \mathrm{s}$ & Nociceptiva. Tato. Temperatura. \\
\hline B & $1.5-3 \mu \mathrm{m}$ & $3-15 \mathrm{~m} / \mathrm{s}$ & Simpáticas pré-ganglionares. \\
\hline C & $<2 \mu \mathrm{m}$ & $0.5-2 \mathrm{~m} / \mathrm{s}$ & Nociceptiva. Simpáticas pós-ganglionares. \\
\hline
\end{tabular}

Legenda: m/s: metros por segundo; $\mu \mathrm{m}$ : micrômetro; VC: velocidade de condução.

\subsection{Fisiologia do Nervo}

Existem dois sistemas de transporte entre o corpo celular do neurônio e a região mais distal do axônio ${ }^{99}$. Esses sistemas permitem o deslocamento de elementos necessários para a manutenção da membrana axonal e estruturas do citoesqueleto, 
mantém as propriedades de condução da fibra e da neurotransmissão através do terminal do axônio e possibilitam a convergência de materiais ao corpo celular que participam do controle dessas atividades ${ }^{99}$. O fluxo é contínuo e de dois tipos de acordo com o sentido do transporte, centrífugo ou anterógrado e centrípeto ou retrógrado, e caracterizado de acordo com a velocidade em lento e rápido. O transporte lento é unidirecional, centrífugo, e sua velocidade varia em torno de dois mm por dia, que é aproximadamente a mesma da taxa de regeneração axonal após uma axoniotomia ${ }^{100}$. Esse transporte é constituído por elementos que mantém a rede de microtúbulos, microfilamentos e neurofilamentos do citoesqueleto ${ }^{101} . \mathrm{O}$ transporte rápido apresenta um componente centrífugo e um centrípeto. Lipídios, glicoproteínas, proteínas secretórias e peptídeos são transportados centrifugamente a uma velocidade de $400 \mathrm{~mm}$ por $\mathrm{dia}^{102}$. Esses elementos repõem os neurotransmissores na região terminal do axônio e auxiliam na restituição do axolema e axoplasma durante o processo de regeneração. $\mathrm{O}$ componente rápido retrógrado recupera as membranas do terminal do axônio através da endocitose e transporte de fragmentos na forma de corpos multivesiculares que são englobados pelos lisossomos no corpo celular. Elementos extracelulares, como fatores de crescimento incorporados no terminal do axônio, também são transportados através desse tipo de fluxo, cuja velocidade é de cerca de $200 \mathrm{~mm}$ por dia $^{102}$.

O processo de transporte é sensível às alterações de temperatura e de teor de oxigênio, já que é dependente do consumo de adenosina trifosfato ${ }^{101,102}$. A alteração de condução do potencial de ação causada pela isquemia é provocada pela interferência com esse mecanismo. 
Fatores que influenciam a VC nas fibras nervosas incluem o diâmetro do axônio, a espessura da bainha de mielina, a distância internodal e a integridade da membrana do axônio ${ }^{103}$. Quanto maior o diâmetro de uma fibra, maior a VC. Nas fibras mielinizadas a relação entre o diâmetro da fibra e a VC é linear enquanto que nas fibras não mielinizadas a VC é proporcional à raiz quadrada do diâmetro.

A fibra nervosa possui a propriedade especial de conduzir um sinal através da propagação de um impulso elétrico denominado de potencial de ação ${ }^{103}$. No pico do potencial de ação o valor do potencial de membrana pode chegar a 50 milivolts $(\mathrm{mV})$ positivos. Nas fibras não mielinizadas uma onda de despolarização se propaga continuamente através do axônio, atenuada pela elevada capacitância do axolema, que limita a VC a um m/s. Nas fibras mielinizadas a propriedade isolante da mielina restringe a atividade elétrica aos nódulos de Ranvier, de forma que o impulso trafega de um nódulo a outro, caracterizando a condução saltatória, possibilitando o aumento da velocidade de condução ${ }^{104}$.

Todos os neurônios possuem um potencial de membrana em repouso, de tal forma que, se um microeletrodo é inserido no interior da célula, a atividade elétrica medida é de aproximadamente $60 \mathrm{mV}$ negativos comparada com a medida no ambiente extracelular $^{103}$. O potencial de repouso depende da atuação de princípios básicos que regulam transporte de íons através da membrana celular. No interior do neurônio a concentração de íons potássio é dez vezes maior em comparação com o fluído extracelular, enquanto que a concentração de íons sódio e cloreto é maior na região extracelular em comparação com o meio intracelular. Esse fato ocorre pois a membrana celular em repouso contém um número abundante de canais de potássio que permitem a passagem desse íon de forma passiva. Na célula em repouso há cerca 
de dez vezes mais canais de potássio abertos em comparação com os canais de sódio e cloreto $^{103}$. O movimento do potássio através da membrana reduz o gradiente de concentração do mesmo, alterando a distribuição das cargas na membrana. A face intracelular da membrana torna-se mais negativamente carregada enquanto que a extracelular torna-se mais positiva. Assim, o potencial de repouso celular é primariamente determinado pelo gradiente de concentração do potássio ${ }^{103}$.

A atividade elétrica do neurônio se inicia a partir de alterações na permeabilidade celular originadas pelos efeitos de neurotransmissores na membrana celular pós-sináptica. Quando a célula é despolarizada até aproximadamente $60 \mathrm{mV}$ negativos a membrana celular torna-se mais permeável ao sódio. Os canais de sódio, que estão fechados durante o repouso, abrem-se por um curto período permitindo o influxo de sódio para o interior da célula. A distribuição dos canais de sódio ao longo da fibra mielinizada possibilita uma maior eficiência na propagação das alterações de polarização. Esses canais estão presentes em alta densidade, cerca de 1500 a 2000 por $\mu \mathrm{m}$ quadrado, na região do nódulo de Ranvier e são responsáveis pela despolarização inicial rápida da membrana durante o potencial de ação ${ }^{70}$. Ao contrário da membrana no nódulo de Ranvier, a membrana internodal, que constitui cerca de 99,9\% do total da membrana axonal, apresenta uma baixa densidade de canais de sódio e alta concentração de canais de potássio ${ }^{70}$. Vários estudos sugerem que a membrana nodal nos mamíferos apresenta pouco ou nenhum canal de potássio $^{105}$. Com o influxo de sódio o interior da célula torna-se positivo, originando um potencial de ação positivo.

Cada canal de sódio é formado por quatro componentes organizados radialmente através da membrana celular ${ }^{106}$. Cada uma destas subunidades contém 
estruturas denominadas de hélice tipo alfa, carregadas positivamente e que são sensíveis às alterações de carga na membrana celular. Durante o repouso a carga positiva das hélices são atraídas pela carga negativa presente no interior da membrana fazendo com que esses componentes ocluam o poro central do canal. Durante a despolarização, com o aumento de cargas positivas no interior da membrana, as hélices do tipo alfa se deslocam em direção à superfície celular ocasionando uma mudança na conformação nos componentes do canal e abrindo o poro central do mesmo. Transcorrido um milissegundo (ms) da sua abertura, o que permite a passagem de cerca de 6000 íons, as hélices retornam à sua posição original, ocluindo novamente o poro do canal ${ }^{106}$. Três tipos de canais de sódio podem ser caracterizados de acordo com constituição da hélice do tipo alfa, diferenciados pela sua ativação ou inativação segundo a voltagem a que são submetidos, pela sua cinética de abertura e pela sensibilidade à tetrodotoxina ${ }^{106}$.

A estrutura dos canais de potássio voltagem dependentes é semelhante a dos canais de sódio. Essa similaridade dos canais voltagem dependentes de potássio e sódio sugere que as proteínas constituintes dos mesmos foram produzidas a partir de um material genético ancestral comum e incorporadas na escala filogenética aos organismos multicelulares ${ }^{107}$.

O potencial de ação pode ser obtido experimentalmente a partir da utilização de estímulo eficaz denominado de limiar ${ }^{103}$. A intensidade do potencial de ação não varia após a aplicação de estímulos de intensidade maior que aquela geradora desse potencial. 


\subsection{O Processo de Regeneração no Sistema Nervoso Periférico}

A secção de um nervo acarreta modificações no corpo celular, nos segmentos proximal e distal à secção, no local da lesão e nos órgãos inervados.

Nas primeiras horas após a lesão do axônio o corpo celular passa a apresentar uma série de alterações denominadas de cromatólise que se caracterizam histologicamente pelo ingurgitamento da célula, degeneração da substância de Nissl e migração do núcleo do centro para a periferia ${ }^{108}$. Quanto mais próxima se localizar a lesão em relação à medula espinhal, mais intensas são estas alterações ${ }^{108}$.

Durante a cromatólise o citoplasma aumenta de volume devido a um incremento na formação de ácido ribonucléico e enzimas relacionadas, cuja finalidade é possibilitar um aumento de produção de componentes protéicos estruturais necessários à regeneração do citoesqueleto ${ }^{109}$. Esse aumento da produção de ácido ribonucléico se inicia quatro dias e atinge um pico 20 dias após a lesão ${ }^{110}$. Nesse processo os ribossomos desprendem-se das lamelas que constituem o retículo endoplasmático e situam-se de forma dispersa no citoplasma, disposição que se traduz na rarefação da substância de Nissl ${ }^{111}$.

Algumas das alterações presentes no corpo celular das células do gânglio da raiz dorsal ocorrem a partir de interações estabelecidas entre o neurônio e os fatores tróficos, muitas vezes produzidos pelas próprias células. Essas alterações são interpretadas como uma recapitulação do padrão de expressão fenotípica presente no processo de desenvolvimento dos nervos. Após uma axoniotomia a concentração de ácido ribonucléico mensageiro relacionado à produção de "glial cell line-derived neurotrophic factor" (GDNF) aumenta rapidamente nos neurônios do gânglio da raiz 
dorsal $^{112}$. A expressão de receptores específicos para fatores neurotróficos como trkB e p75 está aumentada nos motoneurônios após a axoniotomia e a oferta de "brainderived neurotrophic factor" (BDNF) reduz a morte celular em motoneurônios após a axoniotomia em animais neonatos ${ }^{112}$. Apesar dessas observações, evidências recentes sugerem que, apesar de semelhantes, a expressão fenotípica das células do gânglio da raiz dorsal durante o desenvolvimento e na regeneração apresentam algumas particularidades que diferenciam esses processos. Segundo Vogelaar et al, nessas células a regulação da transcrição de elementos presentes na regeneração é diferente da que ocorre durante o desenvolvimento, havendo uma expressão mais significativa de citocinas neuroativas em comparação com as neurotropinas durante a regeneração ${ }^{113}$.

O processo de degeneração e regeneração envolve uma série de alterações celulares secundárias à expressão de vários genes, muito deles inativos no nervo íntegro. No nervo ciático do camundongo o processo de regeneração ocorre através da expressão de cerca de 500 genes $^{114}$.

Recentemente, através de estudos realizados in vitro com axônios em crescimento isolados, têm-se demonstrado que a síntese de proteínas não está só restrita ao corpo celular, mas pode também ocorrer no axônio em regeneração ${ }^{115}$. Essa produção axonal de proteínas teria participação na fase inicial de regeneração, quando o transporte axonal ainda não foi suficiente para conduzir proteínas para o cone de crescimento do axônio em expansão.

As alterações presentes no corpo celular são interpretadas como um incremento do metabolismo celular, que visa a regeneração do citoesqueleto do axônio em detrimento da produção de neurotransmissores ${ }^{116}$. A síntese de componentes do 
citoesqueleto apresenta uma alteração qualitativa durante a regeneração. Dois a quatro dias após uma axoniotomia ocorre uma redução na produção de proteínas relacionadas à constituição dos neurofilamentos e um incremento na síntese de actina e tubulina, elementos constituintes dos microfilamentos e microtúbulos, relacionados ao transporte intracelular e movimentação do cone de crescimento $^{99}$.

As substâncias produzidas no corpo celular são transportadas para a região da lesão através dos componentes centrífugos rápido e lento do transporte axonal com o objetivo principal de suprir elementos constituintes do citoesqueleto e da membrana axonal em expansão ${ }^{99}$. Para um axônio com extensão de $0,5 \mu \mathrm{m}$, a taxa de expansão da membrana plasmática é de aproximadamente um $\mu \mathrm{m}$ quadrado por minuto ${ }^{100}$. Um dos elementos do axolema em expansão são os fosfolipídios. Estudos experimentais demonstram que $50 \%$ da fosfatidilcolina, o principal fosfolipídio da membrana axonal, é produzido localmente e o restante é transportado via transporte axonal, em vesículas, até a região do cone de crescimento ${ }^{100}$. Ao contrário, evidências revelam que a síntese de colesterol, outro importante fosfolipídio constituinte da membrana axonal, só ocorre no corpo celular e sua incorporação à membrana plasmática depende exclusivamente do transporte axoplasmático ${ }^{100}$.

A interrupção da continuidade do axônio impede o transporte axonal, determinando a perda da transmissão sináptica, que cessa horas após a lesão ${ }^{117}$. Quanto mais próxima a lesão estiver da sinapse, mais rápida a ausência de transmissão sináptica se instalará. Assim, um axônio longo que apresenta uma lesão em sua porção proximal pode manter esta transmissão por dias ${ }^{117}$. Embora a velocidade do transporte não sofra alteração, a quantidade de material transportada está aumentada durante o processo de regeneração. 
Após a axoniotomia ocorre um aumento da excitabilidade do corpo do neurônio, dendritos e segmento proximal do axônio. Essa alteração ocorre como conseqüência de modificações na expressão dos tipos de canais de sódio na membrana celular. Nessas condições observa-se um aumento na concentração de canais de sódio do tipo III, ocasionando as alterações de excitabilidade dessas estruturas ${ }^{118}$. Com a evolução do processo de regeneração, a distribuição dos tipos de canais de sódio se aproxima daquela presente na membrana do axônio normal. Os canais de potássio também estão presentes e ativos precocemente durante a regeneração do axônio ${ }^{105}$.

Alterações significativas ocorrem em ambas extremidades do axônio após a lesão. No coto proximal os axônios sofrem um processo de degeneração semelhante ao que ocorre no coto distal, mas geralmente limitado ao nódulo de Ranvier mais proximal $^{112}$. Em situações extremas, o processo de degeneração pode atingir o corpo celular provocando a morte da célula cujo mecanismo mais provável é a apoptose ${ }^{119}$. Em animais adultos após a lesão de nervo pode ocorrer morte de 20 a $40 \%$ dos neurônios no gânglio da raiz dorsal ${ }^{112}$.

$\mathrm{Na}$ extremidade distal as alterações que ocorrem no axônio se iniciam com a degeneração walleriana. Durante esse evento o citoesqueleto e o axoplasma se degeneram, deixando o correspondente tubo endoneural vazio. A destruição da mielina estimula a atividade dos macrófagos resultando na remoção da maioria dos seus fragmentos por essas células e pelas CS, processo que se completa 25 dias após a lesão no nervo ciático do rato ${ }^{120}$. Nas primeiras horas após a lesão as CS iniciam o processo de fagocitose da mielina na área da lesão através da expressão de MAC-2, 
uma lecitina galactose-específica, que interage com os galactolipídios presentes na mielina $^{121,122}$.

O mecanismo preciso responsável pelo recrutamento dos macrófagos durante a degeneração walleriana não está completamente esclarecido, mas evidências sugerem a participação do sistema do complemento, das citocinas, da molécula de adesão ICAM-1 e, principalmente, da interleucina-1, na promoção desse processo ${ }^{46}$, 112, 120, 123, 124, 125. Os macrófagos atuam não só na fagocitose de fragmentos de mielina e do axoplasma, mas também na produção de substâncias que estimulam a proliferação das CS e na produção de fatores neurotróficos como o "nerve growth factor" (NGF) ${ }^{117,123 .}$

De acordo com Durrenberger et $\mathrm{al}^{126}$, resultados obtidos da análise de nervos humanos e de nervos ciáticos do rato submetidos à lesão, confirmam a presença e a atuação das cicloxigenases na degeneração e regeneração dos nervos, com conseqüente produção de prostaglandinas, o que justificaria a ocorrência e persistência da dor durante esses eventos.

A degradação da mielina obedece a um ciclo bioquímico onde parte dos seus constituintes é reutilizada durante a regeneração. A hidrólise dos fosfolipídios originados da mielina ocorre principalmente nos macrófagos e produz ácidos graxos livres $^{121}$. Cerca da metade desses ácidos graxos é reincorporado pelas CS como fosfolipídios e todo o colesterol originado da degradação da mielina une-se à apolipoproteína E, formando partículas lipoprotéicas. Essas partículas são posteriormente utilizadas pelas CS através da sua ligação com receptores para lipoproteínas de baixa densidade para a formação de mielina ${ }^{121}$. A formação da mielina também depende da síntese de proteínas. De acordo com Bolin e Shooter ${ }^{85}$, a 
expressão de genes relacionados à produção de proteínas da mielina, como a proteína

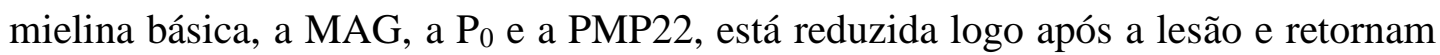
aos níveis normais se a regeneração ocorrer de forma eficiente. A progesterona, que pode ser produzida pelos neurônios e pelas CS, participa do processo de mielinização, principalmente da fase relacionada à produção de $\mathrm{P}_{0}$ e PMP-22, através da regulação da expressão de fatores de transcrição específicos ${ }^{127}$.

O processo de fagocitose ocorre em ambas extremidades do axônio e no local da lesão. Os macrófagos que atuam nesse processo se originam a partir de células pré-existentes no perineuro e endoneuro e de mastócitos recrutados da circulação sangüínea ${ }^{120}$. Essas células secretam uma série de proteinases cuja ação possibilita que as mesmas penetrem e ultrapassem a membrana basal ${ }^{128}$. A atividade dos macrófagos se inicia 24 horas após a lesão axonal e atinge um pico entre o décimo quarto ao vigésimo primeiro dia após a mesma ${ }^{120}$. A partir desse período, essas células passam a deixar o local da lesão ${ }^{121}$.

As CS migram a partir das regiões proximal e distal em direção à área da lesão e organizam-se em colunas identificadas na microscopia óptica como linhas longitudinais no interior dos tubos endoneurais, denominadas bandas de Büngner ${ }^{129}$. Essa proliferação atinge um pico no período do segundo ao quarto dia após a lesão do nervo ${ }^{122}$.

As CS têm um fundamental papel na regeneração, atuando como condutores físicos que possibilitam o direcionamento dos axônios durante o crescimento em direção ao órgão-alvo ${ }^{130}$. Essas células também produzem elementos da ME como proteinoglicanas, colágeno e fatores neurotróficos como NGF, BDNF, "ciliary neurotrophic factor" (CNTF) e GDNF que atuam no corpo celular do neurônio em 
regeneração ${ }^{46}$. A regeneração que ocorre no SNP está diretamente relacionada à possibilidade de manutenção das CS independente da degeneração do axônio. Essa sobrevida, que pode atingir meses no coto distal de animais submetidos à axoniotomia, ocorre pela existência de uma série de sinais celulares produzidos pelas próprias CS e que é independente do contato com os axônios ${ }^{42}$. Os componentes principais desta série de sinais são o IGF, a NT-3, o PGF, o TGF- $\beta$ e o "leukaemia inhibitory factor" ${ }^{\prime 2,131}$.

Assim como ocorre durante a formação dos nervos, após a lesão as CS do coto distal perdem o contato com as fibras nervosas e o fenótipo das mesmas é revertido a uma condição semelhante a das CS precursoras. Esta desdiferenciação é conseqüência das alterações secundárias à expressão de genes que ocorrem nessas células.

No local da lesão modificações estão presentes já nas primeiras 24 horas. O intervalo entre os dois cotos do nervo é preenchido com sangue e é formado um coágulo de fibrina ${ }^{116}$. A este coágulo convergem capilares e fibroblastos de tecidos adjacentes e dos cotos do nervo lesado. Na extremidade do coto proximal, os axônios formam protrusões axoplasmáticas denominadas de brotos de crescimento $^{117}$. Através desse processo cada axônio pode originar vários axônios delimitados pelo perineuro. O brotamento axonal está presente precocemente após a lesão, podendo ser identificado três horas após a mesma ${ }^{129}$. Logo após a formação dos brotos axonais, há um aumento da presença de mitocôndrias e vesículas e essas estruturas passam a ser denominadas de cones de crescimento, sendo consideradas como a extremidade de um axônio bem desenvolvido. 
Vários peptídeos são liberados e foram quantificados no local da lesão e nas células do gânglio da raiz dorsal após uma axoniotomia experimental do nervo. Entre estes estão incluídos a substância P, o peptídeo intestinal vasoativo e a galanina, cuja função durante a degeneração e regeneração permanece incerta ${ }^{109}$. Recentemente Ceballos et al ${ }^{132}$ analisaram o papel das metalotioneinas na regeneração do SNP. A expressão destas proteínas está aumentada em determinadas condições no sistema nervoso central como patologias neurodegenerativas, desmielinizantes e na isquemia. Em um estudo analisando a resposta de camundongos portadores de supressão gênica da produção de uma isoforma desta proteína denominada MT3 após a lesão do nervo ciático, os autores demonstraram que a regeneração é mais eficaz em comparação com os controles. De acordo com os autores, a MT3 atua normalmente inibindo a regeneração nesses animais ${ }^{132}$.

O cone de crescimento possui duas porções, a região do lamelipódio e os filopódios ${ }^{133}$. A região do lamelipódio é definida como a região central da extremidade do cone que está em constante remodelamento pela formação e retração dos filopódios ${ }^{134}$. Essa região mede cerca de cinco $\mu \mathrm{m}$ de diâmetro e é constituída por axoplasma contendo retículo endoplasmático, vesículas e elementos do citoesqueleto $^{135}$. Na periferia do lamelipódio estão localizados filamentos de actina dispostos em forma de uma rede e que, associados à presença de microtúbulos, são responsáveis pela motilidade desta região. Os filopódios são expansões em forma de espículas que se retraem e se estendem a partir da superfície da região do lamelipódio pela contração de filamentos de actina que formam uma rede poligonal complexa no seu interior ${ }^{134}$. Os filopódios apresentam diâmetro entre 0,1 a 0,2 $\mu \mathrm{m}$ e extensão variável que pode chegar a $50 \mu \mathrm{m}$. A membrana celular dessas estruturas 
apresenta grande quantidade de receptores para moléculas de adesão ${ }^{135,136}$. Através dessa disposição, o cone de crescimento atua explorando o microambiente extracelular até que, através da interação de receptores de superfície com estímulos adequados, tais como fatores de crescimento, haja uma reorientação apropriada que possibilite o crescimento axonal em direção ao coto distal e órgão-alvo ${ }^{133}$.

O cálcio exerce um importante papel no crescimento do cone ${ }^{137}$. A redução da sua concentração intracelular, após ativação de receptores específicos como o receptor ligado à proteína $\mathrm{G}$, ocasiona interrupção do crescimento do cone. O efeito inverso é obtido com drogas bloqueadoras da extrusão celular do cálcio e com a ação de agonistas da proteína $\mathrm{G}^{136,137}$.

Inicialmente os brotos de crescimento não são acompanhados pelas CS. Assim, esses brotos não são envolvidos por mielina, mesmo se o axônio de origem for do tipo mielinizado. À medida que os axônios em regeneração progridem em direção ao coto distal do nervo, essas fibras são envolvidas por CS e seu número em cada unidade decresce progressivamente. Esse declínio provavelmente está indiretamente relacionado ao sucesso de contato do axônio com o órgão-alvo distal, mas também é conseqüente à inibição do crescimento dos brotos primordiais através da ação da $\mathrm{MAG}^{138}$. A MAG é uma proteína de membrana expressa pelas CS relacionada ao processo inicial de mielinização e que atua inibindo os brotos de crescimento dos axônios de nervos in vitro e in vivo ${ }^{138}$. Acredita-se que esta atuação na fase inicial do processo de regeneração tenha como objetivo otimizar esse processo e possibilitar a maturação dos primeiros axônios em crescimento.

Para que haja a expansão do cone de crescimento e a formação de uma membrana pré-sináptica é necessária a incorporação de proteínas na extremidade do 
cone. Esse processo de incorporação é determinado através da fusão de vesículas contendo proteínas específicas transportadas retrogradamente do corpo celular ${ }^{139}$. As principais proteínas envolvidas nesse evento são a sinaptofisina, a sinaptotagmina, a sinapsina, a GAP-43, a proteína quinase $\mathrm{C}$ e a tirosina quinase.

A sinaptofisina é considerada um mediador do processo de fusão das vesículas na membrana pré-sináptica e está presente em altas concentrações nos cones de crescimento $^{140}$. A sinaptotagmina apresenta a propriedade de se ligar a fosfolipídios tendo importante papel na fusão das vesículas e incorporação do seu material à membrana plasmática ${ }^{140}$. A sinapsina apresenta a propriedade de se ligar a elementos do citoesqueleto e considera-se que esteja envolvida no direcionamento das vesículas sinápticas até o local de liberação de seu conteúdo ${ }^{141}$.

A GAP-43 também pode receber a denominação de B50, F1, pp46, p57 e neuromodulina, uma vez que foi isolada por vários investigadores de forma independente. A denominação mais utilizada é GAP-43, derivada do peso molecular desta substância que é 43 kilodaltons ${ }^{109}$. A GAP-43 apresenta dois terminais que se ligam à membrana plasmática e a elementos do citoesqueleto. Apresenta também um sítio específico onde interage uma proteína denominada de calmodulina. A fosforilação dessa ligação pela proteína quinase C causa a liberação da calmodulina que está implicada na expansão dos cones de crescimento. A GAP-43 está também relacionada à ativação da proteína $\mathrm{G}$, processo que inibe o crescimento dos cones em culturas de neurônios. A proteína GAP-43 apresenta, portanto, propriedades opostas e acredita-se que seja uma proteína fundamental na transdução de sinais

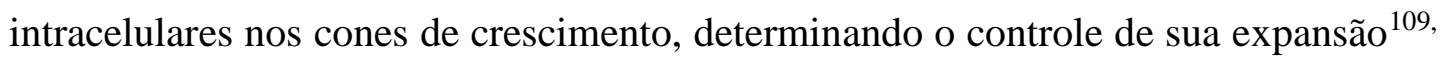
142 . 
A proteína quinase $\mathrm{C}$ é uma enzima fundamental no processo de transdução de sinais intracelulares, estando envolvida numa série de eventos metabólicos celulares $^{143}$. Essa classe de proteínas apresenta três subgrupos e nove subtipos. O subtipo beta está relacionado à membrana dos axônios em crescimento e ao processo de fosforilação da GAP-43. A proteína quinase $\mathrm{C}$ atua no processo de transdução do sinal intracelular iniciado pela ligação de integrinas e laminina in vitro e exerce um papel crítico na facilitação do crescimento axonal ${ }^{143}$. Apesar dessas importantes funções, a inibição da proteína quinase $\mathrm{C}$, em alguns estudos, não interrompe o processo de regeneração. Nestes casos, supõe-se que o processo de fosforilação na regeneração seja exercido de forma compensatória por outras quinases ${ }^{144}$.

A tirosina quinase é uma proteína envolvida na transdução de sinal intracelular que regula a extensão e a motilidade do cone de crescimento. Dois tipos de tirosina quinase podem estar presentes no cone de crescimento, o tipo receptor e o tipo nãoreceptor $^{145}$. O tipo receptor é identificado em associação com extensões intracelulares de receptores para neurotrofinas. O tipo não receptor, também denominado pp $60^{\text {c-scr }}$ ou c-scr, é identificado em altas concentrações no cone de crescimento. A atividade dessa proteína promove a ligação das integrinas com os filamentos de actina e é relacionada com a adesão do cone a elementos da $\mathrm{ME}$ através da sua associação com moléculas de adesão ${ }^{145}$.

Durante a regeneração dos axônios uma série de contatos são estabelecidos entre os mesmos e as CS e a membrana basal. As CS em divisão expressam um fenótipo molecular semelhante ao das CS imaturas e não mielinizadas ${ }^{46,47}$. Nesta fase os receptores expressos na superfície celular das CS pertencem principalmente às famílias das imunoglobulinas e das caderinas, e incluem aqueles relacionados à 
fibrina, à laminina, à fibronectina, à mielina, aos fatores neurotróficos como o NGF e às neuroregulinas, especialmente os receptores c-erbB2, c-erbB3 e c-erbB4 ${ }^{46,} 47,146$. As neuroregulinas constituem uma família de fatores tróficos produzidos pelos neurônios ${ }^{46}$. Uma das neuroregulinas é o GDNF que atua como fator trófico para as células precursoras das CS, estimulando a proliferação celular e atuando na manutenção das CS nas junções neuromusculares em desenvolvimento ${ }^{112}$. Na vida adulta o GDNF atua aumentando a motilidade e a proliferação das CS.

Os cones de crescimento dos axônios em regeneração também expressam uma série de receptores direcionados às moléculas de adesão presentes na superfície interna da membrana basal e nas membranas das CS, propiciando a esses axônios a capacidade de estabelecer adesões entre essas duas estruturas durante seu crescimento $^{139}$. A adesão entre as CS e o axônio em crescimento é modulada em parte por imunoglobulinas como as N-CAM, L1 e as caderinas. Durante o desenvolvimento as N-CAM e a L1 são expressas nas regiões de contato entre as membranas plasmáticas dos axônios e das $\mathrm{CS}^{113}$. Após esta fase há uma redução acentuada na expressão destas moléculas de forma que, nas fibras mielinizadas, há ínfimas quantidades de N-CAM e L1 na região de contato celular entre as CS e o axônio. No entanto, na presença de uma lesão, essas moléculas são expressas novamente na superfície das CS onde há o contato entre as mesmas durante a fase de proliferação, o mesmo ocorrendo na região de contato entre essas células e o axônio em crescimento ${ }^{113}$.

As caderinas são moléculas de adesão celular que participam também das interações entre os axônios em regeneração e as CS. Essas moléculas são divididas em várias subclasses incluindo as E-, B-, P-, R- e N-caderinas e as protocaderinas ${ }^{139}$. 
Evidências experimentais sugerem que as $\mathrm{N}$-caderinas estão relacionadas à adesão entre as CS e os axônios ${ }^{147}$. Sugere-se que as caderinas atuem não só no estabelecimento de adesões, mas também como mediadores do metabolismo de elementos do citoesqueleto durante a regeneração. Os domínios intracelulares dessas moléculas são denominados de cateninas e se ligam a filamentos de actina possibilitando o processo de contração dos mesmos durante a fase de alongamento dos axônios em crescimento, após a interação das caderinas com moléculas específicas $^{139}$. Outras proteínas provavelmente envolvidas no processo de adesão entre os axônios e as CS são a P30, a TAG-1/F3 e a $\mathrm{P}_{0}{ }^{139}$.

Durante as fases precoces da regeneração, os axônios em crescimento estão em contato direto com a ME até que as CS em proliferação atinjam os cones de crescimento. Nesta fase, a regeneração dos axônios é possível pelo estabelecimento de interações entre esses e a membrana basal. A fibronectina e a laminina são glicoproteínas que fazem parte da constituição da membrana basal da célula de Schwann e são o estímulo mais importante para esse tipo de migração, conduzindo o cone de crescimento em direção ao tubo endoneural distal ${ }^{47}$. Receptores específicos localizados na superfície dos axônios em crescimento permitem a adesão entre esses e a laminina- $2^{47}$. O contato entre os axônios e a membrana basal é mediado principalmente pela ligação entre laminina e seus receptores, as integrinas. Essas moléculas são um subgrupo de receptores de adesão constituído por glicoproteínas situadas na membrana que intermediam interações entre o citoplasma e o microambiente extracelular ${ }^{53}$. As integrinas são constituídas por subunidades alfa $(\alpha)$ e beta $(\beta)$ associadas através de ligações não covalentes. Cada subunidade é uma glicoproteína de membrana caracterizada por um domínio extracelular proeminente 
responsável pelas ligações com outras moléculas e por um domínio intracelular, em geral curto, que interage com moléculas citoplasmáticas e componentes do citoesqueleto. Atualmente 20 diferentes subunidade são identificadas formando 22 $\alpha / \beta$ heterodímeros ${ }^{53}$. A interação de integrinas com a fibronectina e a laminina afeta a velocidade e a direção de crescimento do cone durante a embriogênese e a regeneração ${ }^{53}$. As integrinas $\alpha 1 \beta 1$ e $\alpha 5 \beta 1$ estão presente de forma transitória nas CS após a lesão do nervo e provavelmente contribuem para o processo de migração dessas células assim como para o desenvolvimento do cone de crescimento $^{53,146}$. O complexo laminina-integrina promove a adesão e a motilidade do cone de crescimento através da transdução de um sinal intracelular mediado em parte pela proteína quinase $\mathrm{C}$ e que altera a arquitetura do citoesqueleto ${ }^{143}$

A produção de colágeno do tipo I e III permite a constituição de uma rede de suporte para os cones de crescimento. Esta produção é dependente da transcrição de genes que codificam a informação genética para a síntese de pró-colágeno tipo I e tipo III nas células endoneurais. Evidências experimentais comprovam que a expressão genética de componentes da ME, como o colágeno, aumenta com a lesão do nervo ${ }^{74,148}$.

Com a entrada do broto axonal no coto distal ocorre uma segunda onda de proliferação das CS, processo que se estabiliza na medida em que há o estabelecimento de conexões entre os axônios e os órgãos-alvos. A sobrevida das CS no coto distal é fundamental no processo de crescimento do cone. Normalmente a sobrevida das CS se faz principalmente por interações com moléculas liberadas pelo axônio íntegro, principalmente a beta neuroregulina ${ }^{36}$. Com a degeneração dos axônios no coto distal a sobrevida das CS é determinada pela atuação de fatores de 
crescimento como IGF, o PGF e o NT-3, liberados durante a lesão ${ }^{149}$. Segundo Tetzlaff et al e Torigoe et al ${ }^{150,151}$ a morfologia das CS pode ser alterada de acordo com a repetição de uma lesão. Na presença de uma lesão seqüencial ocorre uma alteração no metabolismo das CS resultando num aumento da síntese de tubulina e uma redução na produção de neurofilamentos. Nesses casos, determinadas proteínas liberadas na área de lesão atuariam como fatores de transcrição após interação com receptores presentes na membrana celular destas células, alterando a expressão de genes relacionados às modificações do metabolismo celular. Os fatores de transcrição denominados c-Jun e Jun D participam desse processo e apresentam uma expressão aumentada após a axoniotomia ${ }^{113}$.

A sobrevida dos axônios no coto distal e o sucesso dos mesmos em atingir os órgão-alvos dependem da atuação de fatores neurotróficos e neurotrópicos ${ }^{139}$. O fator neurotrófico é a substância que regula e mantém a função do neurônio e promove o seu crescimento ${ }^{139}$. Todas as células do organismo necessitam da ação de fatores tróficos para prevenir a apoptose e promover a sua sobrevivência.

Os efetores da morte celular são proteases específicas denominadas caspases ${ }^{152}$. Uma vez ativadas estas proteases clivam substratos intracelulares específicos, representados principalmente por proteínas do citoesqueleto e da lâmina nuclear, cuja presença é fundamental para a manutenção da citoarquitetura. Estas últimas são proteínas de membrana que atuam como pontos de adesão para proteínas filamentares formando o arcabouço que mantém a forma esférica do núcleo. $\mathrm{Na}$ ausência de um fator trófico uma proteína pró-apoptose denominada Bad se liga a proteínas anti-apoptose $\mathrm{Bcl}-2$ e Bcl-xl situadas na membrana da mitocôndria ${ }^{152}$. A ligação da Bad previne a interação entre estas proteínas anti-apoptose com uma 
proteína pró-apoptose situada na mesma membrana denominada Bax. Como consequiência, a Bax forma canais na membrana da mitocôndria que permite o influxo de íons e, através de um mecanismo ainda não esclarecido, leva a extrusão do citocromo c do interior desta organela para o citoplasma. O citocromo c inicia uma série de reações através da ativação de uma pró-caspase que culmina com a ativação das caspases. Na presença de um fator trófico ocorre a fosforilação da Bad que permanece seqüestrada no citoplasma e a cascata de eventos descrita não se inicia. Assim, a inibição da formação das caspases possibilita a manutenção dos neurônios após a lesão ${ }^{153}$. No processo de regeneração do nervo, receptores específicos são expressos em maior quantidade na região do cone de crescimento aos quais se unem os fatores neurotróficos específicos ${ }^{122}$. Esses fatores atuam modulando a interação entre as caspases e proteínas pró-apoptóticas através da ocorrência de reações de fosforilação, exercendo seus efeitos diretamente sobre o metabolismo celular.

A ação dos fatores neurotróficos pode ainda ser realizada de forma indireta através da atuação desses no metabolismo de suporte como a célula de Schwann ${ }^{46}$, 131,154

Várias substâncias produzidas no local da lesão atuam como fatores neurotróficos tais como o NGF, o BDNF, o CNTF, o TGF- $\beta$, o FGF e as neurotrofinas $3,4 / 5$ e $6^{46,112,131}$. As neurotrofinas são uma classe de proteínas que incluem o NGF, BDNF, a NT-3, a NT-4/5 e a NT-6, sendo sintetizadas na forma de polipeptídeos precursores e posteriormente clivados nos elementos finais ativos. Após uma axoniotomia o NGF é produzido pelas CS, atingindo um pico de concentração 24 horas após a lesão ${ }^{155}$. Segundo Anton et al ${ }^{154}$, após a lesão as CS elevam a expressão de NGF em cinco vezes e do receptor p75 em 20 a 50 vezes em 
relação à concentração normal. Esse aumento é mantido até que as CS estabeleçam contato com os axônios. A manutenção de altos níveis de produção do NGF pelas CS é regulada pela interleucina-1 produzida pelos macrófagos ${ }^{156}$. Evidências experimentais sugerem que o NGF está relacionado à regeneração de axônios sensoriais $^{46}$. O BDNF está presente em concentrações mínimas nas CS de nervos adultos. A concentração de ácido ribonucléico mensageiro relacionado à transcrição de BDNF aumenta quatro dias após uma axoniotomia e atinge sua concentração máxima quatro semanas após a lesão ${ }^{157}$. O padrão de produção descrito para o BDNF é diferente do apresentado pelo NGF, que atinge a concentração máxima rapidamente, três a quatro dias após a lesão ${ }^{155}$. Além disso, o BDNF é mais eficaz em promover a sobrevida de axônios motores em crescimento em comparação com a manutenção da sobrevida dos neurônios sensoriais e simpáticos ${ }^{131}$. Assim, esses dois fatores neurotróficos parecem exercer suas atividades de maneira complementar no processo de regeneração.

Dois tipos de receptores para neurotrofinas foram identificados. O receptor denominado p75 apresenta baixa afinidade por NGF e seu mecanismo de ativação é ainda pouco esclarecido ${ }^{112}$. O segundo tipo representa uma classe de receptores denominados de "tropomyosin receptor kinase" (trk) constituído por três receptores denominados trkA, trkB e trkC e codificados por proto-oncogenes relacionados ${ }^{158}$. Essas proteínas apresentam um domínio extracelular ao qual se liga a NT, um domínio transmembranoso e um citoplasmático. A interação das neurotrofinas com os receptores trk é específica. O NGF interage com o receptor trkA, o BDNF e o NT$4 / 5$ com o receptor trkB e o NT-3 com o receptor trkC $C^{46}$. A ativação dos receptores 
trk pelos seus respectivos fatores inicia uma série de modificações bioquímicas que culminam com a modulação das caspases e possibilitam a sobrevivência celular ${ }^{46}$.

Outras substâncias, algumas delas exógenas e de mecanismo de ação desconhecido, promovem o crescimento axonal, direta ou indiretamente, in vitro e várias destas têm demonstrado eficácia em estudos in vivo. Entre estas substâncias, as principais são as poliaminas, os ativadores da adenilciclase, as difenilpiperazinas, os gangliosídeos e os imunossupressores como a ciclosporina e o FK506 131, 159, 160, 161.

O fator neurotrópico é o que exerce atração à distância sobre axônios em crescimento $^{131}$. Esta atração pode ser específica para determinado tecido como músculo ou pele ou direcionada topograficamente para um determinado ramo de um nervo a partir do coto distal. Esta especificidade pode ser ainda determinada pelo tipo de fibra nervosa, sensitiva ou motora ${ }^{73}, 162$. O mecanismo celular do neurotropismo ainda não está completamente esclarecido, mas evidências sugerem a participação das CS. As CS que acompanham os axônios motores expressam uma proteína de superfície denominada L2 que está ausente nas CS relacionadas aos axônios sensitivos. Axônios motores em crescimento estabeleceriam relações com as CS específicas de acordo com a sua expressão no coto distal ${ }^{112}$.

Elementos da ME também exercem um importante papel durante a regeneração ${ }^{71}$. As glicosaminoglicanas (GAGS) são polímeros longos de unidades de dissacarídeos ${ }^{73}$. Proteoglicanas, constituídas por GAGS em associação com uma região central de proteína, estão presentes de forma abundante nos tecidos endoneurais envolvendo a membrana basal da célula de Schwann após a lesão do nervo $^{163}$. Uma dessas proteoglicanas, a "chondrotin sulfate-bearing proteoglycan", 
tem ação inibitória na regeneração axonal e sua degradação aumenta o ingresso de axônios em crescimento no segmento distal do nervo seccionado ${ }^{163,164}$. O mesmo ocorre com outras GAGS da ME como o ácido hialurônico ${ }^{38}$. Outros componentes da ME como a laminina e a fibronectina promovem e orientam o crescimento dos axônios em regeneração ${ }^{38,47,122,164}$.

A tenascina $\mathrm{C}$ é uma proteína da $\mathrm{ME}$ que se liga a uma molécula de adesão denominada F3 e modula o crescimento axonal pela interação entre axônios e CS ${ }^{114}$.

Metaloproteinases (MPs) são as enzimas responsáveis pela degradação de componentes da matriz extracelular e da membrana basal, como a laminina e o colágeno tipo IV, e sua ação pode ser anulada através da atuação de inibidores específicos como o TIMP-1. As MPs participam do processo de degradação de restos celulares e de mielina durante a degeneração, possibilitando a continuidade do processo de regeneração ${ }^{165}$. Após axoniotomia do nervo ciático do rato a expressão de metaloproteinase (MP)-9 ou gelatinase B é rapidamente induzida nas CS do segmento distal, atingindo um pico de concentração no terceiro dia após a secção ${ }^{165}$. A localização da produção dessa enzima sugere a sua participação na degradação de restos de mielina. Padrão de distribuição semelhante ocorre com a MP-3 ou estromelisina-1, porém, ao contrário das outras MPs, a MP-3 é a única enzima que apresenta produção reduzida durante a degeneração walleriana. A produção de outras enzimas como a MP-2 ou gelatinase A e a MP-7 ou matrilisina foram identificadas em culturas de CS humanas ${ }^{165}$. Estas MPs apresentam a capacidade de degradar a mielina e componentes da membrana basal.

Apesar da ativação de várias MPs após a lesão, a membrana basal no nervo é relativamente bem preservada durante esse evento. Estudos experimentais 
demonstram que, após uma lesão no nervo ciático, além da produção de MPs há também indução de ácido ribonucléico mensageiro específico, levando à expressão de TIMP-1 que inibe a ação das proteinases ativadas, protegendo a membrana basal da degradação descontrolada ${ }^{128,166}$.

Se a regeneração dos axônios não ocorrer, alterações podem se desenvolver nos órgãos alvos. As fibras musculares tornam-se atróficas, apresentando-se mais arredondadas e com o núcleo deslocado da sua posição original periférica para o centro da célula. Parte dessas alterações pode ser identificada algumas semanas após a lesão. As placas motoras também se tornam atróficas e desaparecem, processo que se inicia três meses após a lesão axonal. O tecido muscular é substituído por tecido fibrótico no período de 12 a 24 meses após a lesão do nervo ${ }^{139}$.

\subsection{Métodos Experimentais de Avaliação da Regeneração}

Nos estudos experimentais diversos parâmetros são utilizados para avaliar a regeneração após lesão ou secção de um nervo. As avaliações mais freqüentemente utilizadas são a funcional, a eletrofisiológica e a histomorfométrica ${ }^{167,168,169,170}$.

A avaliação funcional pode ser realizada através da obtenção de índices a partir de medidas realizadas nas impressões das patas do animal operado, durante a marcha ${ }^{167,168}$. Alguns autores consideram esse tipo de teste como o mais eficaz na avaliação da regeneração, pois permite avaliar uma série de etapas complexas que resultam no processo final, ou seja, a marcha ${ }^{169,}{ }^{171}$. Para ser eficiente a marcha 
necessita de uma reinervação motora complexa que depende do retorno de informação sensorial, mecanismos que são integrados corticalmente. Durante a recuperação do animal é necessário que haja uma reorganização central nas vias envolvidas no movimento. Assim, embora seja necessária a integridade da reinervação de receptores musculares e sensitivos, cuja função pode ser avaliada indiretamente por outros métodos, alterações nas vias do sistema nervoso central podem prejudicar a efetividade da marcha ao não impedirem a contração de um músculo antagonista ${ }^{172}$.

A avaliação da marcha pode ser prejudicada, ou mesmo impossibilitada, pela presença de complicações após a lesão do nervo como deformidades e autotomia das patas operadas.

As deformidades na pata podem ocorrer secundariamente à desnervação da musculatura resultando em paralisia e conseqüente anquilose $\operatorname{articular}^{172}$. Além disso, a regeneração pode ocorrer através de vias inadequadas resultando na inervação de músculos antagonistas ${ }^{172}$.

A autotomia da pata pode ocorrer durante experimentos que causam uma lesão do nervo ciático. Esse tipo de comportamento pode resultar em diferentes tipos de lesões nos membros operados, podendo ocorrer em até $88 \%$ dos casos na literatura, inviabilizando a aplicação do teste da marcha e, geralmente, levando ao sacrifício do animal $^{173}$. A sua incidência é variável de acordo com o tipo de animal utilizado, tipo de lesão aplicada ao nervo, sexo e tratamento medicamentoso utilizado ${ }^{173}$. A autotomia ocorre mais freqüentemente nos animais da raça Sprague-Dawley, naqueles de sexo masculino e nos submetidos a neurectomia. A autotomia se reduz com o uso de guanetidina, difenilhidantoína, morfina e amitriptilina. A fisiopatologia 
da autotomia permanece incerta mas atualmente duas teorias são consideradas. Uma sugere que o comportamento ocorre com o objetivo de eliminar o membro desnervado, insensível e inútil, uma vez que os animais não apresentam sinais de sofrimento devido à dor crônica, tais como perda de peso, capacidade de procriação e de cuidar de filhotes ${ }^{174}$. Outra teoria para explicar a ocorrência da autotomia, mais amplamente aceita, sugere que esse comportamento ocorra pela presença de uma sensação anormal de características disestésicas com conotação dolorosa secundária às modificações neuronais que ocorrem após a secção do nervo ${ }^{175}$.

A avaliação eletrofisiológica é geralmente realizada através dos dados obtidos pela avaliação do potencial de ação do nervo (PAN) e do potencial de ação motor (PAM). Esta avaliação permite quantificar a latência, amplitude e velocidade de condução dos potenciais realizados ${ }^{171}$.

O PAN pode ser considerado como um potencial de ação composto, pois é o resultado da soma algébrica dos potenciais de ação de fibras únicas (PAFU) ${ }^{176}$. A amplitude dos potenciais obtidos no registro extracelular depende da distância entre o axolema e o eletrodo de registro e das propriedades elétricas do tecido não neural interposto entre o nervo e o eletrodo. Ao contrário dos PAFUs, que apresentam sempre a mesma amplitude, a magnitude do PAN é variável e depende do número de fibras ativadas, da distância entre as fibras e o eletrodo de registro e da condutividade elétrica dos tecidos vizinhos. Após a lesão a magnitude e a forma do PAN são influenciadas pela quantidade de tecido fibrótico formado, pelo suprimento vascular e pela taxa de tecido neural e não neural, além dos fatores descritos ${ }^{176}$. A VC varia de acordo com as características estruturais do axônio como o diâmetro, distância internodal, área nodal e espessura da mielina, e com alterações no estado fisiológico 
do animal como variações de temperatura e do metabolismo. A variação da VC relaciona-se diretamente com a variação do diâmetro axonal ${ }^{177}$. Se a espessura da mielina é reduzida pode haver uma perda excessiva de corrente internodal. Uma parte dessa corrente se transmite pelo axônio, que apresenta baixa condutância e alta capacitância, levando à redução da $\mathrm{VC}^{177}$.

De acordo com Rosen e Jewett ${ }^{178}$, com o estudo eletrofisiológico é possível avaliar a função dos axônios condutores mensurando, portanto, a função de uma subpopulação dos axônios que atravessaram a região de reparo. Além da mensuração do PAN a avaliação eletrofisiológica pode incluir a avaliação do PAM, cujos parâmetros permite quantificar, através da medida da latência, amplitude e VC, a função dos axônios condutores que ultrapassaram a região do reparo e atingiram o músculo estudado.

A avaliação histomorfométrica possibilita a realização da contagem de axônios e da medida de seus diâmetros, assim como a quantificação da espessura da bainha de mielina ${ }^{167}$. Esse método de avaliação pode incluir a mensuração desses parâmetros nas regiões proximal, distal e no local do reparo. Esse tipo de avaliação possibilita quantificar o número de axônios que ultrapassaram o local da lesão através da relação entre a contagem dos mesmos nas regiões distal e proximal à região do reparo. No nervo normal este índice, em alguns trabalhos denominado de índice de regeneração (IReg), é igual a um ou $100 \%$, o que significa que o número de fibras é o mesmo nos segmentos considerados. Um índice reduzido indica uma passagem insatisfatória dos axônios em regeneração para o coto distal e um índice elevado geralmente é considerado como um fator favorável após o reparo ${ }^{167}$. O 
índice pode ser superior a um e, nesse caso, a ocorrência de um número maior de axônios na região distal ao local de reparo é creditada ao brotamento axonal ${ }^{178}$.

A mensuração do diâmetro é um indicador indireto da qualidade da regeneração, ou seja, do grau de maturação destas fibras ${ }^{167}$. Quanto menor o diâmetro axonal, mais lenta é a condução dos impulsos no segmento distal ao reparo. De forma semelhante à mensuração da contagem de axônios, a avaliação do diâmetro pode ser realizada nas regiões proximal e distal à região do reparo, possibilitando que se avalie a influência de fatores locais nesse parâmetro.

Há dois importantes pré-requisitos para uma função apropriada de um nervo. Como requisito fundamental, os axônios devem ser capazes de transmitir impulsos através da manutenção da sua condição histológica. A morfometria é uma ferramenta eficiente para monitorar este primeiro pré-requisito ${ }^{167}$. No entanto, os parâmetros obtidos com essa análise freqüentemente não se correlacionam com a função da marcha já que uma regeneração cruzada ocorrida através do brotamento pode levar a erros na direção das fibras, resultando em alteração da função. O reduzido número de fibras regeneradas e a mielinização insatisfatória geralmente se correlacionam com uma função ruim, mas o contrário não é verdadeiro.

Diversos estudos comparam e analisam a eficácia desses métodos para a avaliação da regeneração tentando estabelecer uma possível correlação entre os

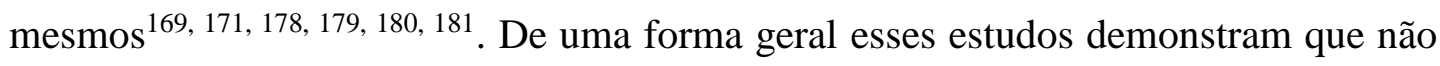
há uma correlação entre os parâmetros de avaliação da regeneração, a não ser quando são comparados a velocidade de condução com o diâmetro da fibra regenerada ${ }^{171,180}$. Os autores sugerem que os métodos avaliam fases distintas da regeneração e que, portanto, não podem ser comparáveis. 


\subsection{Técnicas Empregadas no Reparo de Lesões de Nervos}

\subsubsection{Histórico}

Little cita que até o terceiro século a.C. os nervos eram considerados estruturas indistinguíveis dos tendões ${ }^{182}$. Nesta época, Herófilos descreveu o trajeto dos nervos desde os membros até a medula espinhal e diferenciou os nervos sensitivos e motores. O reconhecimento do nervo como uma estrutura anatômica distinta dos tendões foi realizada por Galeno na segunda metade do século II depois de Cristo $(\text { d.C. })^{182}$.

O primeiro reparo descrito em um nervo foi realizado por Paulo de Aegina*, citado por Little ${ }^{182}$, no século VII d.C.. Do final do Primeiro Milênio até a Idade Média a investigação e o tratamento das lesões de nervos permaneceram restritas a raras descrições e, com a confirmação da continuidade do sistema nervoso periférico e central, a sutura de nervos foi evitada, pois a ela era creditada a ocorrência de epilepsia $^{182}$. Guy de Chauliac**, citado por Almquist ${ }^{183}$ e considerado o maior cirurgião entre os séculos XIV e XV, relatou boa evolução em pacientes após ter realizado sutura de nervos e observou que essa recuperação era mais efetiva em pacientes jovens quando comparada com a dos idosos.

\footnotetext{
* Paulus Aegineta. Seven books of Paulus Aegineta embraced a complete view of the knowledge passed by the greeks, romans and arabians on all subjects connected with medicine and surgery, translated by F. Adams, vol. 2, Londres, Sydenham Society, 1844-1847.

** Guy de Chauliac on wounds and fractures (translated by W.A. Brennan), W.A.Brennan, Chicago, 1923.
} 
A partir do século XV até o século XVII os relatos de procedimentos cirúrgicos envolvendo os nervos foram também inexpressivos, culminando com a recomendação de contra-indicação do tratamento cirúrgico em lesões de nervos pelos cirurgiões britânicos que assistiam aos soldados nas Guerras Napoleônicas ${ }^{184}$.

Em 1850, após centenas de anos de negação da possibilidade de regeneração do SNP, Augustus Waller*, citado por $\mathrm{Naff}^{184}$, caracterizou pela primeira vez a degeneração distal após secção dos nervos glossofaríngeo e hipoglosso de sapos e descreveu sua subseqüente regeneração. Ramon y Cajal**, citado por Almquist $^{183}$, em 1928, demonstrou que a regeneração de fibras nervosas ocorria a partir do coto proximal de um nervo lesado e não através da regeneração da porção distal, como até então se acreditava. Através do seu tratado o autor definiu conceitos inovadores sobre a histologia e as alterações presentes durante a regeneração dos nervos que persistem até hoje. Essa contribuição permitiu uma maior aceitação pelos cirurgiões dos procedimentos cirúrgicos envolvendo os nervos, que passaram a ser explorados mais intensamente a partir da Primeira Guerra Mundial ${ }^{184}$.

Nesta época o reparo era realizado através da sutura término-terminal mesmo sob tensão, mas com a recomendação de se imobilizar as articulações de forma a impedir o estiramento da sutura. Passado o período de cicatrização, as articulações eram estendidas progressivamente durante meses para que fosse possível a distensão do nervo ${ }^{184}$. Durante a Segunda Guerra Mundial foi verificado que os resultados do reparo com a técnica descrita não apresentavam uma recuperação aceitável, devido à formação de fibrose secundária à tração do nervo ${ }^{185}$.

*Waller A. Experiments on the section of the glosso-pharyngeal and hypoglossal nerves of the frog and observations on the alteration produced thereby in the structure of their primitive fibres. Philos Trans $R$ Soc Lond. 1850; 140: 423-9.

**Cajal S. Degeneration and regeneration of the nervous system. Translated by May RM, 1928. New York: Hafner, 1968. 
Em 1810 Philipeaux e Vulpian*, citados por Mackinnon e Dellon ${ }^{186}$, descreveram os primeiros experimentos onde foram utilizados enxertos unindo dois cotos de um nervo. No trabalho desses autores um segmento do nervo lingual do cão foi utilizado para reconstruir o nervo hipoglosso. No homem o primeiro uso clínico de enxerto foi o realizado por Albert** em 1885, citado por Mackinnon e Dellon ${ }^{186}$. Esse autor descreveu a reconstrução da distância de 3,5 centímetros $(\mathrm{cm})$ entre os cotos do nervo mediano, resultante da ressecção de um sarcoma que o envolvia. O enxerto foi retirado de uma perna amputada de outro paciente e necessitou ser ressecado posteriormente devido à ocorrência de necrose local. Em 1917, MayoRobson***, citado por Mackinnon e Dellon ${ }^{186}$, relatou a obtenção de bom resultado após a reconstrução de uma lesão do nervo mediano com enxertos de $2,5 \mathrm{~cm}$.

Credita-se a Seddon a popularização do uso de enxertos no reparo de nervos com grande perda de substância. Com a técnica empregada pelo autor resultados satisfatórios foram obtidos a partir da Segunda Guerra Mundial ${ }^{187}$. Após a década de 60, a introdução de instrumentos de magnificação, como lupas e microscópios, durante as cirurgias de nervos, possibilitou a obtenção de melhores resultados refletidos na publicação de diversos autores ${ }^{184}$.

O estudo histológico do nervo recebeu uma importante contribuição com os trabalhos de Sunderland que caracterizou a anatomia interna e a estrutura fascicular dos nervos mediano, radial e ulnar em cadáveres humanos ${ }^{188}$. Com os estudos desse autor foi possível estabelecer descrições detalhadas da organização tecidual intraneural, o que estimulou diversos autores a realizar o reparo direto dos fascículos, com ou sem interposição de enxertos ${ }^{188}$.

\footnotetext{
*Philipeaux JM, Vulpian A. Note sur sa essais de greffe d'untroncon de nerf lingual entre lês deux vouts de thypoglose. Arch Physiol Norm Pathol. 1817; 3: 618-23.

**Albert E. Einige opertionen an nerven. Wien Med Presse. 1885;26:1285-7.

***Mayo-Robson AW. Nerve grafting as a means of restoring function in limbs paralysed by gunshot or other injuries. Br Med J 1917;1:117.
} 
Em 1972, Millesi et al ${ }^{189}$ relataram o primeiro caso onde foi utilizado um enxerto interfascicular numa lesão de nervo em humanos. Esses autores introduziram o conceito da necessidade da ausência de tensão no reparo de nervos com a utilização de enxertos autólogos e sistematizaram o uso de técnicas microcirúrgicas no tratamento dessas lesões.

A história do uso de adesivos no reparo de lesões teciduais inicia-se a partir do reconhecimento de escritas egípcias datadas de 2500 a.C. que descreviam métodos de aproximação de feridas em partes moles, consistindo no alinhamento de suas bordas e a aplicação de graxa e mel para possibilitar a oclusão e cicatrização ${ }^{183}$. Supõe-se que Galeno, no ano de 200 a.C., tenha sido o primeiro cirurgião a utilizar um preparado à base de albumina de ovo para obter a aproximação dos cotos de um nervo, procedimento também realizado por Roger de Parma no século treze ${ }^{182,183}$.

Em 1932, Ballance e Duel ${ }^{190}$ descreveram um caso onde a coaptação de um enxerto utilizado na reconstrução do nervo facial intratemporal foi realizada através de um coágulo obtido a partir do plasma. Em 1940, Young e Medawar² relataram o uso de uma combinação de plasma e concentrado de fibrinogênio obtido do sangue de galo na coaptação de cotos de nervos de coelhos e cães. Baseados nos resultados da avaliação histológica os autores concluíram que o método era superior à sutura convencional. Dois anos mais tarde, Seddon e Medawar ${ }^{4}$ utilizaram esse método em humanos e relataram resultados satisfatórios, assim como Tarlov ${ }^{191}$ em 1944. Devido à dificuldade de obtenção desse tipo de adesivo a sua utilização foi abandonada nas três décadas seguintes. Com o advento de um adesivo tecidual produzido a partir do 
fibrinogênio humano em escala comercial, o uso de adesivos no reparo de nervos passou a ser mais freqüente a partir da década de $70^{183}$.

O reparo de uma lesão por transecção pode ser direto ou através da interposição de enxertos entre os cotos do nervo, quando o reparo direto não pode ser utilizado devido à excessiva tensão existente na linha de sutura ${ }^{192}$. Apesar de ser uma técnica amplamente utilizada, o uso de enxertos na reconstrução de um nervo pode apresentar efeitos indesejados como a maior ocorrência de fibrose pela existência de duas linhas de sutura, reinervação incompleta pela dificuldade de alinhamento dos fascículos e alterações relacionadas à retirada do nervo doador ${ }^{193}$. A partir da identificação dessas complicações vários trabalhos passaram a investigar um substituto do enxerto autólogo para a utilização como condutor das fibras regeneradas no reparo das lesões de nervos. O uso dos condutores permitiria a realização do reparo com menor risco de invasão de tecido fibrótico na linha de sutura, preveniria a formação de um neuroma em continuidade e possibilitaria o acúmulo e/ou oferta de fatores neurotrópicos e neurotróficos que facilitariam o desenvolvimento da regeneração ${ }^{193}$.

A primeira tentativa experimental de se realizar um reparo de nervo com um condutor foi executada em 1880 por Gluck*, citado por Little ${ }^{182}$, com o uso de fragmentos de ossos descalcificados dispostos entre os cotos do nervo ciático de galinhas. Onze anos mais tarde Bungnar**, citado por Fields et $\mathrm{a}^{194}$, utilizou um segmento da artéria braquial como condutor no nervo hipoglosso do cão e relatou a presença de fasciculações na musculatura da língua reinervada.

*Gluck T. Ueber neuroplastik auf dem wege der transplantation. Arch Klin Chir. 1880;25: 606-16.

**B Bungnar OV. Die Degenerations und regenerations. Vorgange am nerven nack verletzungen beitr. Pathol Anat; 1891;10:321-93. 
O uso de um fragmento de veia como condutor foi realizado em 1904 por Foramitti*, citado por Fields et $\mathrm{al}^{194}$. O interesse pela utilização dos condutores aumentou após o final da Segunda Guerra Mundial. A partir desta data, Weiss publicou uma série de trabalhos analisando a utilização de condutores e caracterizando as alterações histológicas que ocorrem no interior deste tipo de reparo $^{195}$. Na década de oitenta diversos estudos passaram a investigar a eficácia de condutores de diferentes origens ${ }^{194,196 .}$

\subsubsection{Utilização de Condutores no Reparo de Lesões de}

\section{Nervos}

O papel de condutor pode ser exercido por tubos constituídos por veias, artérias, tecido muscular e diferentes materiais, orgânicos ou não, biodegradáveis ou não ${ }^{193}$. A limitação desta técnica é a extensão do intervalo entre os cotos e, conseqüentemente, o comprimento do condutor. No nervo ciático do rato bons resultados na regeneração axonal só são obtidos com o uso de condutores com extensão máxima de $10 \mathrm{~mm}^{197}$. Após dias de instalação de um condutor uma matriz de fibrina é formada no seu interior, cuja quantidade é crítica para o processo de regeneração. Se o comprimento do condutor for excessivo não há formação desta matriz ou a matriz formada apresenta uma constituição deficiente nos seus elementos principais, como a laminina e a fibronectina ${ }^{197}$. Além disso, o uso de condutores de materiais duráveis como o silicone pode levar à compressão do reparo ou a uma 
reação inflamatória que muitas vezes exige uma segunda cirurgia para a sua retirada $^{198}$.

Diversos estudos apresentam bons resultados com o uso de condutores no reparo de nervos humanos ${ }^{198,}$ 199, 200, 201. Nesses estudos o comprimento dos condutores utilizados varia de 0,5 a três $\mathrm{cm}$. Weber et al relataram resultados superiores utilizando condutores bioabsorvíveis de ácido poliglicóico em lesões de nervos nas mãos em comparação com o reparo convencional ${ }^{200}$. Dois estudos na literatura comparam o uso de condutores constituídos por silicone com a técnica convencional de microsutura em enxertos de lesões de nervos ulnar e mediano no homem com os resultados do seguimento da análise de uma série de pacientes após um e cinco anos da cirurgia. De acordo com esses trabalhos, as técnicas são equivalentes com relação à recuperação da sensibilidade e da força muscular ${ }^{198,201}$.

\subsubsection{Técnicas Empregadas na Coaptação de Nervos}

\section{Seccionados}

$\mathrm{Na}$ reconstrução direta de um nervo a coaptação dos cotos proximal e distal geralmente é realizada através de uma sutura com pontos separados. Métodos não rotineiros, como a aplicação de fitas adesivas, lâminas de artérias congeladas e membranas constituídads por colágeno bovino, já foram utilizados para promover a coaptação de nervos em estudos experimentais, com bons resultados em relação à regeneração, porém com aplicação prática questionável ${ }^{195,202,203,204}$. 
A coaptação através de acopladores metálicos utilizados em microcirurgia vascular foi descrita experimentalmente por Prevel et $\mathrm{al}^{205}$ com resultados equivalentes quanto à regeneração do nervo ciático do rato em comparação à sutura tradicional. Park et $\mathrm{al}^{206}$ analisaram a utilização de acopladores de titânio que envolviam os cotos de nervos ciáticos de ratos previamente seccionados. A técnica foi considerada promissora já que os resultados demonstraram taxas de regeneração equivalentes entre esse tipo de coaptação e a sutura com pontos, quando analisado o número de axônios regenerados.

A presença da sutura no nervo ocasiona duas respostas distintas do organismo. A primeira é uma resposta celular caracterizada pela presença e ação de células polimorfonucleares, linfócitos, células gigantes e histiócitos cuja atividade é direcionada à remoção do material implantado ${ }^{207}$. A reação é mais intensa precocemente após a instalação do material e permanece mesmo que a sutura seja absorvida ou isolada pela resposta fibroblástica, o segundo tipo de reação. Essa é constituída pela atividade de células do tecido conjuntivo, como fibroblastos, e direciona-se a selar o material de sutura, formando o tecido residual que persiste após a remoção da mesma pelos fagócitos, quando absorvível. Baseado nesses eventos, a intensidade da resposta fibroblástica é diretamente dependente do material utilizado.

Nos primeiros estudos sobre a eficácia da sutura direta no nervo, diversos materiais foram utilizados tais como cabelo humano, seda, aço inoxidável e categute que, com exceção deste último, não ocasionavam reação inflamatória exuberante ${ }^{207}$. Análises subseqüentes indicaram que o náilon monofilamentar apresentava uma resposta inflamatória semelhante à obtida com a sutura com fios de aço e com fios 
absorvíveis, com a vantagem de ser um material mais facilmente manipulável ${ }^{208}$, sendo utilizado preferencialmente neste tipo de terapêutica ${ }^{209}$.

Utilizando a sutura com fios absorvíveis constituídos por ácido poliglicóico, vários autores demonstraram resultados comparáveis em trabalhos experimentais desse tipo de fio com a sutura realizada com fios de náilon ${ }^{210,211}$. Atualmente a sutura com fios de náilon é a técnica mais difundida no reparo das lesões de nervos.

A rafia epineural e a sutura entre grupos de fascículos são os métodos mais freqüentemente empregados para o reparo direto de um nervo ${ }^{212}$. Na sutura epineural a agulha atravessa o epineuro externo dos dois cotos. O padrão de distribuição dos vasos epineurais pode ser útil para o alinhamento da rafia. Um segundo ponto é realizado em oposição ao primeiro e um mínimo de pontos deve ser utilizado entre esses, permitindo uma coaptação adequada e evitando-se traumatismo cirúrgico que pode ocasionar uma reação de corpo estranho resultando no comprometimento da regeneração ${ }^{1}$.

A sutura entre grupos de fascículos é utilizada quando a área de secção transversa de um nervo é extensa, permitindo a coaptação mais eficaz e possibilitando um alinhamento mais efetivo dos fascículos ${ }^{212}$.

Outra opção de reparo é a sutura fascicular onde a rafia é realizada entre os fascículos do coto proximal e distal do nervo ${ }^{213}$. Esta técnica exige maior dissecção e manipulação dos fascículos, mas permite um alinhamento mais eficiente em relação às suturas epineural e entre grupos de fascículos. Apesar da descrição de numerosos estudos clínicos e experimentais que comparam os resultados da regeneração após a utilização da sutura epineural ou fascicular, não há evidências consistentes de que um método seja superior ao outro 213 . 


\subsubsection{Utilização de Adesivos na Coaptação de Nervos Seccionados}

Existem situações onde o reparo de lesões de nervos é tecnicamente de difícil execução, particularmente em lesões das raízes do plexo braquial próximas ao forame intervertebral ou no interior deste, lesões do nervo facial intratemporal e na coaptação de nervos de diâmetros reduzidos. Nesses casos, a coaptação direta pode ser também obtida com a utilização de adesivos teciduais de forma isolada ou em associação com a sutura convencional.

Os adesivos teciduais podem ser biológicos ou não. Os adesivos não biológicos incluem o cianoacrilato e seus derivados ${ }^{214}$. Os adesivos constituídos por cianoacrilato apresentam maior poder de aderência quando comparados aos adesivos de fibrina e são utilizados em tecido ósseo, cartilagem e na adesão de placas metálicas. Devido à sua alta toxicidade aos tecidos humanos e à sua potencialidade de produzir uma reação inflamatória intensa, o uso dos adesivos de cianoacrilato para o reparo de lesões de nervos permanece limitado a estudos experimentais ${ }^{215,216,217 .}$

Sandvoss et al $^{218}$ compararam a atuação do adesivo de fibrina com a coaptação obtida com um adesivo de cianoacrilato e com a utilização de uma canaleta de silicone que possibilitou a união dos cotos, sem reparo cirúrgico, do nervo oculomotor do gato previamente seccionado. Nos cinco animais onde foi utilizado o adesivo constituído por cianoacrilato, os resultados foram desfavoráveis devido à ocorrência de atrofia do nervo e adesões cicatriciais.

Wlodarczyk ${ }^{219}$ comparou os efeitos de adesivos constituídos por cianoacrilato e fibrina sobre as características do potencial de ação do nervo tibial isolado de sapos 
banhados por esses adesivos. Previamente à adição do adesivo os nervos foram tratados com enzimas específicas com a finalidade de se reduzir a quantidade de tecido conjuntivo dos mesmos. O adesivo constituído por cianoacrilato aboliu a atividade elétrica enquanto que os potenciais de ação dos nervos banhados com adesivo de fibrina foram superiores aos obtidos no grupo controle banhado com solução de sacarose.

Wieken et $\mathrm{al}^{217}$ demonstraram que a utilização do cianoacrilato para o reparo ocasiona intensa reação inflamatória e constrição do diâmetro do nervo, com prejuízo da regeneração. No estudo desses autores, a regeneração no nervo ciático do rato previamente seccionado foi mais efetiva quando utilizado o adesivo de fibrina.

Os adesivos biológicos são representados principalmente pelos adesivos constituídos a partir da fibrina. Adesivos à base de plaquetas também foram descritos, mas seu uso é limitado devido à dificuldade para a sua obtenção ${ }^{214}$. Esses adesivos apresentam uma alta concentração de plaquetas e baixa concentração de fibrinogênio, sendo obtidos a partir da centrifugação de sangue autológo e foram utilizados para a oclusão de feridas e na reconstrução de fraturas de face e de mandíbula. Nesses casos o adesivo é utilizado misturado a partículas ósseas ${ }^{214}$.

Dois estudos da literatura avaliaram outros tipos de adesivos de forma experimental. Iuan et $\mathrm{al}^{220}$ descreveram a utilização de um adesivo constituído a partir do veneno de cobra do gênero Crotalus. Os resultados foram comparáveis aos obtidos com o adesivo de fibrina tradicional, porém publicados como resultados preliminares, sem posterior investigação complementar. Parker et al $^{221}$ compararam a eficácia de um adesivo constituído por colágeno microfibrilar com a sutura convencional após a secção e reparo do nervo facial extratemporal em coelhos. $\mathrm{Na}$ 
análise dos resultados foram avaliadas a mobilidade da musculatura facial após estimulação intra-operatória, realizada de forma subjetiva, e as alterações histológicas. Essa avaliação foi realizada através da quantificação do brotamento axonal, da organização tecidual, da presença de neuroma e do alinhamento dos axônios. Os autores concluíram que os dois métodos foram funcionalmente equivalentes, mas o reparo com a sutura apresentou melhores resultados histológicos.

O adesivo de fibrina é formado no momento da sua aplicação. Existem vários produtos comerciais que diferem na dosagem de seus componentes. Todas as formulações incluem fibrinogênio na concentração que varia de 30 a 115 miligramas (mg) por mililitro, na maioria das vezes associado ao fator XIII, na concentração de um a 80 unidades por mililitro. A aprotinina bovina é adicionada a estes dois componentes e o conjunto acrescentado a uma mistura de trombina na concentração de 200 a 500 unidades internacionais por mililitro e cloreto de cálcio na quantidade de 5,88 mg. A soma desses componentes reproduz a última etapa do processo de coagulação $0^{222}$.

O fibrinogênio é constituído por seis cadeias de polipeptídios de três diferentes tipos denominados alfa, beta e gama que são simetricamente organizados em pares. Uma vez misturados, a trombina cliva as cadeias do fibrinogênio e leva a formação de monômeros de fibrina ${ }^{222}$. Devido à presença de forças intermoleculares, principalmente na forma de pontes de hidrogênio, esses monômeros se agregam produzindo fibrina solúvel. O fator XIII atua como pró-enzima em uma reação de catalização desses agregados. Com a ação desse fator, na presença de íons de cálcio, as moléculas agregadas de fibrina passam a ser unidas por pontes de isopeptídeos resultando na formação de uma rede de fibrina insolúvel. A aprotinina, um inibidor 
da ação do fibrinogênio obtido de tecido pulmonar bovino, atua como um agente anti-fibrinolítico nessa reação, impedindo a rápida degradação do coágulo 222 .

A união das cadeias de fibrina ocorre em duas etapas. Na etapa inicial apenas as cadeias gama participam da reação, que se completa no período de três a 10 minutos. Segue-se a esta etapa uma fase mais lenta da reação onde as cadeias ligadas são as do tipo alfa. Nesta fase $80 \%$ das cadeias estão unidas duas horas após a mistura e $100 \%$ após 24 horas $^{222}$. A força de adesão aumenta com o tempo, atingindo um patamar de estabilização 100 minutos após a aplicação do adesivo ${ }^{214}$.

A análise da coaptação do tecido da córnea durante cirurgia para correção de catarata em coelhos demonstrou que a tensão na ferida cirúrgica logo após o fechamento é semelhante quando utilizados a sutura com um ponto, o adesivo de fibrina ou o cianoacrilato ${ }^{223}$. Maragh et $\mathrm{al}^{24}$ comparando a aplicação do adesivo de fibrina e a utilização da sutura convencional no reparo de nervos ciáticos do rato previamente seccionados, não identificaram diferenças significativas na tensão da região da coaptação após duas, quatro e oito semanas do reparo. Mattar $\mathrm{Jr}^{21}$ comparou a resistência à tração em animais submetidos ao reparo após a secção do nervo ciático com sutura convencional e com o adesivo de fibrina. $\mathrm{O}$ autor concluiu que o adesivo de fibrina possui uma resistência à tração menor que a sutura microcirúrgica epineural convencional.

Os componentes dos adesivos de fibrina podem ser obtidos através do plasma de doadores ou do próprio paciente $224,225,226$. Para a constituição do adesivo autólogo é necessária a retirada prévia de sangue do próprio paciente, possibilitando a obtenção de fibrinogênio a partir do plasma, geralmente através de uma técnica de precipitação na presença de etanol ${ }^{227}$. A trombina para a utilização nesse tipo de 
adesivo é obtida comercialmente e geralmente é de origem bovina. A principal vantagem desse tipo de adesivo sobre o obtido a partir do plasma de doadores é a ausência da necessidade de testes para detecção de doenças infecto-contagiosas de transmissão sangüínea. A desvantagem desse adesivo é a baixa concentração de fibrinogênio obtida em alguns preparos, o que prejudica a sua capacidade de $\operatorname{adesão}^{214}$.

O adesivo de fibrina tem sido utilizado no homem em vários procedimentos a partir da década de 80, incluindo cirurgias abdominais e endoscópicas, cirurgia torácica, vascular, otorrinolaringológica e neurológica ${ }^{228}$. Nessas situações o adesivo atua como um selante de anastomoses, agente hemostático em leito cirúrgico, como material obliterante de cavidades e como adjuvante no tratamento da fístula liquórica $^{228}$. Mais recentemente tem-se estudado experimentalmente a utilização do adesivo de fibrina como um meio para a oferta de fatores neurotróficos no local da lesão do nervo, com resultados favoráveis à utilização dessa técnica ${ }^{229}$.

Nas utilizações descritas no homem, a tolerabilidade ao adesivo de fibrina é alta, comprovada pelos dados obtidos de cerca de um milhão de aplicações do mesmo. Desses casos, apenas duas reações adversas, incluindo broncoespasmo severo e choque anafilático, foram creditadas ao adesivo de fibrina ${ }^{228}$.

Três componentes do adesivo são originários do plasma humano. No tipo de adesivo utilizado neste estudo os doadores são testados para a presença de anticorpos para os vírus da hepatite B, C e imunodeficiência humana adquirida HIV-1 e HIV-2 e recusados caso haja uma história familiar de doença de Creutzfeldt-Jakob. Os doadores também são recusados quando receberam transplante de córnea, hormônio 
de crescimento ou gonadotrofina humana ou necessitaram de enxertos de dura-máter previamente conservada ${ }^{228}$.

O processo de produção do adesivo inclui uma etapa de pasteurização onde os componentes são aquecidos em solução aquosa numa temperatura de 60 graus Celsius durante 10 horas, procedimento que inativa os vírus potencialmente contaminantes $^{228}$. Nenhum caso de contaminação viral ou bacteriana foi associado ao uso do adesivo de fibrina na literatura ${ }^{18}$.

Estudos realizados em ratos com fibrinogênio marcado com iodo radioativo demonstraram que os coágulos formados no tecido subcutâneo ou na cavidade peritoneal, a partir do adesivo, são progressivamente recobertos por tecido conjuntivo, reduzindo a sua presença progressivamente até não serem identificados 30 dias após sua aplicação ${ }^{230}$.

Estudos experimentais comprovam que a interposição do adesivo de fibrina entre os cotos do nervo seccionado não atua como uma barreira e permite a regeneração de forma equivalente em relação à sutura convencional ${ }^{231}, 232,233$. De acordo com Mattar $\mathrm{Jr}^{21}$, o tempo de progressão dos axônios em regeneração em nervos ciáticos de ratos submetidos ao reparo com sutura e adesivo de fibrina são semelhantes.

Segundo diversos autores o adesivo de fibrina possui vantagens em comparação com a sutura convencional no reparo de nervos seccionados. O seu uso possibilitaria uma redução da reação inflamatória, presente quando a sutura é realizada, e simplificaria a técnica com conseqüente redução do tempo cirúrgico ${ }^{17,18,30,234}$.

Outros autores citam como principais desvantagens a ocorrência de reação inflamatória pela presença do adesivo, uma maior dificuldade de alinhamento dos 
cotos em comparação à sutura e uma menor resistência à tensão, com maior possibilidade da ocorrência de deiscência ${ }^{11}, 12,24,235$. Segundo Matras et $\mathrm{al}^{236}$ a resistência à tração, quando utilizado o adesivo de fibrina para a coaptação de cotos de nervos seccionados, aumenta de acordo com o aumento da concentração de fibrinogênio e adição do fator XIII. De acordo com Jin et $\mathrm{al}^{23}$ e Maragh et $\mathrm{al}^{24}$ a deiscência com a utilização do adesivo ocorre quando há tensão no local do reparo imediatamente após a aplicação. Segundo Maragh et al $^{24}$, Narakas $^{234}$ e Matras ${ }^{237}$ essa complicação pode ser evitada através da imobilização da área do reparo logo após a utilização do adesivo por um período de três minutos, mas idealmente a área cirúrgica deve ficar livre da ação de forças de tensão até duas semanas após o reparo.

Dos estudos experimentais que avaliaram a eficácia do adesivo de fibrina em comparação com a sutura, quatro informaram se houve ou não deiscência entre os cotos coaptados ${ }^{12,23,24,28}$. Nos estudos de Jin et $\mathrm{al}^{23}$, Maragh et $\mathrm{al}^{24}$, Cruz et $\mathrm{al}^{12} \mathrm{e}$ Sames et $\mathrm{al}^{28}$ a incidência desta intercorrência foi de $10,5 \%, 13 \%, 80 \%$ e $20 \%$, respectivamente. A alta incidência de deiscência nos estudos de Cruz et al $^{12}$ e Sames et $\mathrm{al}^{28}$ pode ser justificada pelo fato dos autores utilizarem adesivo autólogo onde a concentração de fibrinogênio, fundamental para a eficácia do adesivo, é difícil de ser prevista no produto final e geralmente é inferior à concentração presente nos adesivos obtidos comercialmente. Os autores não informaram a concentração final de fibrinogênio do adesivo nos seus estudos.

Na literatura 43 estudos analisam os resultados da regeneração após a lesão de nervos com adesivos de fibrina. Dez trabalhos relatam os resultados do reparo com adesivo de fibrina em lesões de nervos extracranianos no homem, seja ele realizado com ou sem interposição de enxertos. Em três desses, o número de casos foi limitado 
ou apresentado como relato de caso $^{4,}$ 15, 191 . Dos estudos restantes, quatro apresentaram resultados em séries clínicas com um número de pacientes superior a $30^{238,239,240,241}$. Esses trabalhos mostraram que a coaptação de nervos com adesivo de fibrina no homem era factível e poderia produzir bons resultados. Três trabalhos tentaram estabelecer uma comparação entre a sutura tradicional e a coaptação com adesivo de fibrina ${ }^{20,234,242}$. Nesses trabalhos, os autores relataram que os resultados com o adesivo foram comparáveis ou superiores aos obtidos com a sutura, conclusões questionáveis devido a problemas metodológicos. Esses estudos foram realizados de forma retrospectiva, compararam resultados de reparos realizados em diferentes localizações topográficas e nem sempre o reparo foi realizado pelo mesmo cirurgião. A complexidade de se realizar um estudo bem controlado em humanos ocorre devido à dificuldade de se comparar a regeneração no mesmo nervo lesado, com o mesmo mecanismo de lesão, em local idêntico e cujo mecanismo de reparo foi tecnicamente semelhante. Portanto, a eficácia deste tipo de terapêutica se restringe à análise dos estudos experimentais.

Quando analisados os trabalhos experimentais que compararam a utilização do adesivo de fibrina com a sutura epineural no reparo direto de nervos extracranianos,

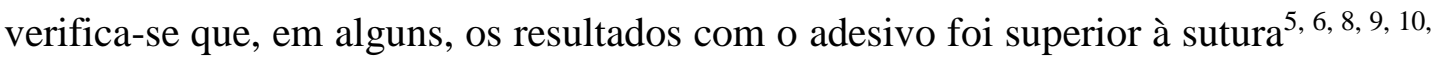
$13,18,23,25,27,29$, em outros a sutura foi mais eficaz que o adesivo ${ }^{7,12,14,17,22,24,28}$ e em um terceiro grupo os resultados foram semelhantes entre as duas técnicas 11, 15, 16, 19, 20, 21, 26, 30 . Além dessa contradição, a comparação dos resultados entre esses estudos geralmente é impossível, pois a metodologia de análise freqüentemente foi incompleta, utilizou métodos de análise diferentes e, em certos casos, essa análise foi baseada em critérios subjetivos como a avaliação visual da efetividade da sutura, 
grau de cicatrização na linha de sutura e as condições da pata e da realização da $\operatorname{marcha}^{5,6,8,9,13,26}$.

Robinson e Madison $^{243}$ analisaram um aspecto da regeneração que é a ocorrência de reinervação motora preferencial após a regeneração axonal. Através da reinervação motora preferencial, os axônios de nervos mistos, que apresentam um ramo sensitivo e um motor distal a uma lesão, se direcionam de forma preferencial e de acordo com a constituição do coto distal, sensitivo ou motor, após o reparo. A reinervação motora preferencial é particularmente observada nos nervos femorais de ratos, que apresentam um ramo motor para o músculo quadríceps e um ramo cutâneo para a face plantar da pata. No estudo desses autores, a reinervação motora preferencial foi descrita pela primeira vez no nervo femoral do camundongo apenas quando o reparo de uma secção proximal desse nervo foi realizado com o adesivo de fibrina, o que não ocorreu com a sutura convencional. De acordo com os autores, esse fenômeno não foi descrito anteriormente devido à espessura reduzida do nervo no camundongo e conseqüente regeneração ineficaz proporcionada pela sutura convencional em comparação com aquela observada com o adesivo de fibrina ${ }^{243}$. Apesar das conclusões dos autores, o trabalho em questão avaliou apenas a ocorrência do neurotropismo, mas não mensurou outro parâmetro associado à regeneração que poderia estar alterado de forma concomitante de acordo com o grupo de reparo adotado.

Quatro modelos animais foram utilizados nos estudos que avaliam e comparam a regeneração com o adesivo de fibrina e a sutura convencional. Em coelhos cinco estudos foram realizados $2,3,13,17,28$. Young e Medawar $^{2}$ em seu estudo que incluía além de coelhos, três cães, verificaram apenas que o reparo de nervos seccionados 
com o adesivo de fibrina era possível. Tarlov e Benjamin ${ }^{3}$ avaliaram a coaptação com adesivos de diferentes origens e identificaram processo inflamatório mais exuberante quando o adesivo se originava do plasma humano e de galo em comparação com o adesivo autólogo. Feldman et $\mathrm{al}^{13}$, Moy et $\mathrm{al}^{17}$ e Sames et $\mathrm{al}^{28}$ compararam os resultados da utilização do adesivo de fibrina com a sutura convencional. Feldman et $\mathrm{al}^{13}$ avaliaram a recuperação clínica baseada na medida do diâmetro da coxa, presença de deformidades, habilidade de flexão da pata e a quantidade de axônios regenerados, com resultados mais favoráveis ao adesivo de fibrina. Moy et al $^{17}$ avaliaram de forma subjetiva o padrão das patas, analisaram os resultados da eletromiografia assim como o grau de organização das fibras nervosas e o grau de processo inflamatório presente no local de reparo. Os resultados foram mais favoráveis no grupo de animais cujos nervos foram coaptados com a sutura. No estudo de Sames et al $^{28}$ a avaliação foi realizada através da quantificação da perda sensitiva cutânea na pata e da integridade do reparo, além da avaliação através da medida do potencial de ação do nervo. Nesse estudo não houve diferença significativa entre os grupos, mas o tempo de preparo do adesivo, por ser constituído a partir de sangue autólogo, ultrapassou o tempo da realização da sutura.

Utilizando o gato como modelo experimental apenas um estudo foi publicado ${ }^{18}$. Nesse trabalho, 30 animais foram submetidos ao reparo do nervo facial intratemporal previamente seccionado, divididos em três grupos de acordo com o procedimento utilizado, sutura epineural com dois pontos, adesivo de fibrina ou oposição dos cotos sem qualquer método de junção. A avaliação foi realizada graduando-se a mobilidade e simetria facial, a presença ou não de axônios e de infiltrado inflamatório ou fibrose em amostras histológicas do nervo e mensurando-se o 
potencial de ação motor, avaliado no ângulo labial, após estimulação do nervo durante a reoperação. Os autores concluíram que o adesivo de fibrina apresentava melhores resultados em comparação à sutura tradicional na coaptação intratemporal do nervo facial ${ }^{18}$.

$\mathrm{O}$ rato foi o modelo experimental mais utilizado nos estudos que avaliaram a efetividade do adesivo de fibrina na coaptação direta de nervos. Vinte e seis estudos analisam e comparam os resultados da regeneração com a utilização do adesivo de fibrina e a sutura epineural. Ventura et $\mathrm{al}^{5}$ analisaram a eficácia de tipos diferentes de reparo em quatro grupos contendo 10 animais cada após a secção do nervo ciático. Os reparos utilizados foram a sutura tradicional, a oposição dos fascículos sem sutura com o auxílio de uma placa contendo três canaletas longitudinais, o adesivo de fibrina com a utilização da placa e o adesivo de fibrina de forma isolada. Os autores concluíram que o uso do adesivo de fibrina possibilitou uma regeneração mais rápida e completa em comparação com a sutura epineural, mas o estudo avaliou apenas as condições das patas, as características da marcha e a presença, sem quantificação, das fibras regeneradas nos cortes histológicos. Ventura e Confalonieri ${ }^{8}$ dividiram 20 animais em dois grupos de acordo com o tipo de reparo empregado após a secção do nervo ciático do rato. Em 10 animais o reparo foi realizado com um adesivo de fibrina e em 10 com a sutura convencional. Os autores observaram a capacidade de realização da marcha através de exame clínico diário, lesões existentes nas patas e sua evolução e a organização histológica das fibras regeneradas. De acordo com esses autores, nos animais onde o reparo foi realizado com o adesivo de fibrina a recuperação da marcha ocorreu de forma mais precoce e a disposição das fibras 
regeneradas foi mais regular em comparação com o grupo de animais onde foi realizada a sutura convencional.

Bignotti $^{6}$ avaliou a eficácia da utilização do adesivo de fibrina e a sutura convencional em 40 animais, divididos igualitariamente em dois grupos. A avaliação consistiu da análise da mobilidade do animal, trofismo da pata, observação do aspecto macroscópico da área do reparo e verificação da continuidade das fibras nervosas no exame histológico, sem quantificação das mesmas. O autor concluiu que o adesivo de fibrina proporcionava um reparo mais efetivo em comparação com a sutura com pontos. Ratto et $\mathrm{al}^{7}$ compararam os dados obtidos com a avaliação do PAN na reoperação de 15 animais, sendo seis pertencentes ao grupo onde o reparo foi realizado com a sutura convencional e nove ao grupo de animais onde foi utilizado um adesivo de fibrina. Os animais foram reoperados nos períodos de 20 e 60 dias após o reparo. Nos resultados, a amplitude do potencial obtida foi semelhante nos dois grupos, mas a latência foi estatisticamente maior no grupo de animais onde a coaptação dos cotos seccionados foi realizada com o adesivo. Os autores concluíram que o processo de regeneração com o adesivo foi mais lento em comparação com a sutura.

Boedts e Bouckaert $^{9}$ apresentaram resultados preliminares favoráveis à utilização do adesivo de fibrina em comparação com a sutura epineural, mas não informaram a metodologia utilizada para a avaliação dos dois métodos. O estudo de Faldini et al ${ }^{10}$ demonstrou melhores resultados no uso de adesivo em comparação com a sutura de náilon no nervo fibular de ratos quando avaliada a contração isométrica do músculo extensor longo dos dedos. Em dois estudos, Becker et al ${ }^{11,244}$ avaliaram a atividade metabólica das CS e das células musculares através da 
quantificação do fosfato radioativo incorporado por estas células em animais submetidos ao reparo do nervo ciático seccionado com sutura epineural e adesivo de fibrina. Os resultados dos dois métodos foram equivalentes.

No estudo de Cruz et al $^{12}$ os animais foram divididos em quatro grupos de acordo com o método utilizado no reparo do nervo ciático. Foram empregados a sutura com seis pontos, a sutura com dois pontos, a sutura com dois pontos associada ao adesivo e o adesivo de forma isolada. O fibrinogênio para a constituição do adesivo foi obtido a partir de amostras do sangue centrifugado do próprio animal. Os autores concluíram que o adesivo e sua combinação com a sutura foram os piores métodos de reparo. A avaliação da regeneração foi restrita à análise da histologia dos nervos com a demonstração, mas não quantificação, de fibras nervosas regeneradas e à presença e ao aspecto da reação inflamatória. Avaliação semelhante foi utilizada por Boedts ${ }^{235}$. No estudo desse autor a utilização do adesivo de fibrina foi relacionada à reação inflamatória mais intensa.

No estudo de Hamm et al $^{14}$ a regeneração obtida com a sutura epineural dos cotos dos nervos seccionados foi comparada com a observada na coaptação com a utilização do adesivo de fibrina associado a um ponto. Esse trabalho avaliou subjetivamente apenas o aspecto dos nervos na histologia, concluindo-se que o reparo com o adesivo deveria ser evitado. No mesmo artigo de Merle et al ${ }^{15}$ onde os autores relatam a experiência com o uso do adesivo de fibrina no homem, há a descrição de uma série experimental comparando a utilização do adesivo de fibrina e a sutura na coaptação do nervo ciático seccionado em 250 animais. Nessa série avaliou-se o metabolismo muscular através da quantificação da incorporação do fosfato radioativo nas células musculares e o aspecto e a orientação das fibras 
nervosas regeneradas na avaliação histológica. Segundo os autores não houve diferença entre os dois métodos de reparo para os parâmetros analisados.

Smahel et al $^{16}$ avaliaram as alterações tróficas das patas e as alterações eletrofisiológicas do PAN em ratos submetidos à secção do nervo ciático e reparo com sutura epineural ou adesivo de fibrina. Os parâmetros obtidos do PAN foram expressos em gráficos sem citação de valores no texto. Nesse trabalho os autores também descreveram as alterações histológicas observadas nos animais que foram sacrificados em épocas pré-determinadas do período pós-operatório. Não houve diferença estatisticamente significativa entre os dois métodos.

Benfrech et al $^{19}$ não identificaram diferenças significativas na densidade histológica das fibras nervosas regeneradas dos nervos ciáticos submetidos ao reparo com adesivo de fibrina e sutura. No estudo de Gilbert ${ }^{20}$ o reparo foi realizado com o adesivo de fibrina em um lado e com a sutura epineural no nervo ciático contralateral do mesmo animal. Os resultados da eletromiografia não mostraram diferenças significativas entre os métodos, mas na análise quantitativa das fibras nervosas regeneradas, os cortes histológicos provenientes dos nervos onde os reparos foram realizados com o adesivo apresentaram resultados estatisticamente superiores. Mattar $\mathrm{Jr}^{21}$, em tese de mestrado apresentada na Faculdade de Medicina da Universidade de São Paulo, comparou a sutura epineural e a reconstrução com adesivo de fibrina em nervos ciáticos de ratos através da contagem do número de fibras mielinizadas e da avaliação da resistência do reparo à tração. A análise histomorfométrica foi realizada após dividir os grupos de reparo em três subgrupos de cinco animais cada, com tempo de observação de 40, 47 e 54 dias após a realização do reparo. Essa análise incluiu a contagem dos axônios mielinizados regenerados em cinco campos de 186 
micrômetros cada, nos segmentos proximal e distal ao reparo. O autor concluiu que o adesivo de fibrina possui uma resistência à tração menor que a sutura e apresenta resultados semelhantes quando considerada a contagem de fibras mielinizadas após a regeneração.

Nishihira e McCaffrey ${ }^{22}$ compararam a força de contração muscular após estímulo e o PAN de dois grupos de animais submetidos à secção do nervo ciático e reparo com sutura convencional e com o de adesivo de fibrina. Os valores obtidos com o registro do PAN foram expressos em gráficos sem citação de valores no texto. Com os resultados obtidos, os autores concluíram que o reparo convencional é preferível à utilização do adesivo, que deve ser aplicado apenas quando a sutura é de difícil ou impossível execução ou como um suplemento da sutura convencional.

$\mathrm{O}$ estudo de Jin et $\mathrm{al}^{23}$ comparou os dois métodos através de testes musculares com quantificação do grau de paralisia e avaliação da resposta à eletroestimulação. A análise histológica consistiu na observação do sucesso ou não da coaptação, mensuração do diâmetro e densidade dos axônios e avaliação da reação de corpo estranho. Segundo os autores, devido aos resultados equivalentes na função do nervo e melhores resultados obtidos na avaliação do grau de processo inflamatório, o adesivo de fibrina é preferível à sutura. Apesar das conclusões observadas, os autores não identificarem diferenças significativas no diâmetro médio dos axônios nas regiões proximal e distal ao reparo.

Zhou $^{25}$ avaliou e comparou a eficácia de um adesivo de fibrina produzido comercialmente, de um adesivo produzido pelo próprio autor e da sutura convencional em 40 animais cujos nervos ciáticos foram seccionados e reparados bilateralmente. Quando utilizado o adesivo de fabricação própria, o autor envolveu a 
região do reparo com uma membrana de colágeno. Os animais foram divididos em dois grupos de acordo com a avaliação final. Em oito animais os nervos foram processados para uma avaliação histológica onde foram quantificados a ocorrência de células de Schwann, a degeneração vacuolar nos axônios regenerados, o número de células inflamatórias e a densidade dos axônios regenerados. Trinta e dois animais foram avaliados através da contagem de axônios na região proximal e distal ao reparo e da espessura da bainha de mielina, além da avaliação da amplitude e velocidade de condução do PAN e do peso do músculo gastrocnêmio. Os valores obtidos com o registro do PAN foram expressos em forma de gráficos sem citação de valores no texto. Em todos os parâmetros estudados o adesivo de fibrina foi superior à sutura convencional.

No estudo de Maragh et $\mathrm{al}^{24}$ a sutura epineural foi superior em comparação ao adesivo de fibrina na avaliação eletrofisiológica com o estudo do PAN, mas a análise histomorfométrica não demonstrou diferenças estatisticamente significativas entre a contagem e a mensuração da área dos axônios regenerados em cortes histológicos obtidos sete mm proximal e distal ao reparo. Em dois artigos Povlsen ${ }^{26,245}$ avaliou e comparou um adesivo de fibrina com a sutura epineural na coaptação do nervo ciático analisando as alterações na microscopia eletrônica, mensurando o número e diâmetro dos axônios nos ramos terminais do nervo e avaliando a recuperação da sensibilidade da pata. Considerando os parâmetros descritos, nesses estudos os dois métodos produziram resultados equivalentes.

Inalöz et $\mathrm{al}^{27}$ compararam o reparo após secção bilateral do nervo ciático do rato em dois grupos de 15 animais cada. O reparo foi realizado com adesivo de fibrina e sutura em dois grupos e em um terceiro grupo, considerado controle, os 
animais foram submetidos apenas à exploração do nervo sem secção do mesmo. A avaliação incluiu a realização de eletromiografia após um mês do reparo e a análise histológica que caracterizava a reação inflamatória. De uma forma geral os autores concluíram que o reparo com adesivo de fibrina foi superior em relação à sutura ${ }^{27}$.

Zhang et al $^{29}$ compararam a sutura com a utilização do adesivo de fibrina associado a dois pontos de ancoramento epineurais em 20 animais. Imediatamente após o reparo e após oito semanas da cirurgia, os autores avaliaram a latência, amplitude e velocidade de condução do PAN, além da histomorfometria. Os valores do PAN foram expressos na forma de um coeficiente, mas não se informou os valores de cada parâmetro de forma isolada. Na avaliação histológica os autores verificaram o aspecto dos cortes axiais dos nervos nos dois grupos além de quantificarem os axônios no segmento proximal e distal ao reparo. Nos dois parâmetros avaliados a cola foi estatisticamente superior à sutura.

Menovsky e Beek $^{246}$ avaliaram a regeneração do nervo ciático do rato após a sua secção de acordo com o reparo em três grupos de oito animais cada. No primeiro grupo, a junção dos cotos do nervo foi realizada com dois pontos de fio de náilon associados à aplicação de laser de gás carbônico sobre albumina bovina no ponto de reparo. No segundo grupo o reparo foi realizado com dois pontos de fio de náilon associado à aplicação de adesivo de fibrina e no terceiro grupo foi utilizada a sutura convencional com quatro a seis pontos de fios de náilon. O reparo realizado exclusivamente com adesivo de fibrina não foi avaliado nesse estudo. A avaliação incluiu a mensuração da distância do primeiro ao quinto dedo durante a marcha, que não mostrou diferença significativa entre os grupos. Em todos os grupos o número dos axônios nos segmento distal ao reparo foi superior ao proximal, mas o diâmetro 
dos mesmos foi significantemente menor no segmento distal. Não houve diferença significativa entre o número, densidade e diâmetro dos axônios nos segmentos proximal e distal nos três grupos analisados.

No estudo mais recente da literatura que compara os dois métodos, Suri et al ${ }^{30}$ avaliaram a evolução temporal da reação inflamatória presente em dois grupos de animais cujos nervos ciáticos foram submetidos à secção e reparo com três pontos ou com adesivo de fibrina. Os autores não identificaram diferenças entre os dois tipos de coaptação de acordo com esse parâmetro.

Em nenhum dos estudos citados a análise funcional através da avaliação do índice funcional ciático foi realizada.

Dos seis estudos na literatura que analisam o PAN como parâmetro de avaliação da regeneração do nervo ciático do rato após a sua secção e reparo com adesivo à base de fibrina, apenas dois informaram os valores dos parâmetros obtidos 7, 16, 20, 22, 24, 25, 29 . No estudo de Zhang et al ${ }^{29}$, os valores da latência e VC do PAN não foram expressos, mas os autores compararam dois coeficientes obtidos com a avaliação desse parâmetro nos nervos ciáticos reparados com adesivo ou sutura. $\mathrm{O}$ coeficiente de regeneração baseado na latência foi calculado dividindo-se a latência inicial pela final e o baseado na VC foi obtido dividindo-se a VC inicial pela VC final. Em nenhum desses estudos, a análise eletrofisiológica incluiu um grupo onde o reparo foi realizado com a associação de sutura e adesivo.

A tabela 2 resume os parâmetros eletrofisiológicos relacionados à mensuração do PAN avaliados nesses estudos. 
Tabela 2 - Parâmetros obtidos na avaliação do potencial de ação do nervo nos estudos da literatura que avaliam a eficácia do adesivo de fibrina para o reparo após secção do nervo ciático.

\begin{tabular}{|c|c|c|c|c|}
\hline \multirow{2}{*}{ PARÂMETRO } & & \multicolumn{3}{|c|}{ TIPO DE REPARO } \\
\hline \multirow{2}{*}{ LAT (ms) } & ESTUDO & SUTURA & ADESIVO & CONTROLE \\
\cline { 2 - 5 } & ${\text { Ratto et } \mathrm{al}^{7}}$ & 0,69 & 2,98 & - \\
\hline Maragh et $\mathrm{al}^{24}$ & 1,40 & 1,41 & - \\
\hline \multirow{2}{*}{ VC (m/s) } & Ratto et $\mathrm{al}^{7}$ & 141,1 & 102,9 & - \\
\cline { 2 - 5 } & ${\text { Maragh et } \mathrm{al}^{24}}$ & 0,46 & 0,19 & - \\
\cline { 2 - 5 } & Sames et $\mathrm{al}^{28}$ & 10,7 & 13,09 & 50,3 \\
\hline CR Lat & Zhang et $\mathrm{al}^{29}$ & $161,94 \%$ & $139,94 \%$ & - \\
\hline CR VC & & $65,09 \%$ & $74,81 \%$ & - \\
\hline
\end{tabular}

Legenda: AMPLIT: amplitude; CR Lat: coeficiente de regeneração baseado na latência; CR VC: coeficiente de regeneração baseado na velocidade de condução.LAT: latência; m/s: metro por segundo; ms: milissegundo; $\mathrm{mV}$ : milivolt; VC: velocidade de condução.

Um estudo da literatura avaliou o PAN na regeneração do nervo ciático do coelho, comparando os resultados do reparo com sutura com quatro pontos e com adesivo autólogo de fibrina após a secção do nervo, em dois grupos de dez animais $\operatorname{cada}^{28}$. A avaliação da VC do potencial foi realizada após três meses da cirurgia e evidenciou que a VC nesta época, nos dois grupos, foi cerca de $20 \%$ do valor obtido na mensuração de um grupo controle constituído por cinco animais.

Apenas um estudo avaliou o PAM, na forma da mensuração de sua latência, após o reparo com adesivo de fibrina ou sutura do nervo ciático do rato seccionado ${ }^{27}$. Nesse trabalho, publicado por Inalöz et $\mathrm{al}^{27}$, os autores informaram o valor médio da latência dos potenciais obtidos um mês após o reparo nos animais submetidos à 
secção dos nervos e para os animais de um grupo controle onde foi realizada apenas a exploração dos nervos.

No estudo de Moy et $\mathrm{al}^{17}$, realizado em coelhos, os valores obtidos na avaliação do PAM no lado operado foram divididos pelos valores realizados no lado são, contralateral ao reparo, em três períodos distintos e expressos em porcentagens. Os valores da VC foram informados como intervalos de variação semelhantes nos dois grupos de reparo, 85 a $87 \%$ após seis e doze semanas do reparo e 97 a 98 \% após dezoito semanas do mesmo.

A tabela 3 apresenta os valores dos parâmetros dos potenciais de ação motor obtidos nesses dois estudos.

Tabela 3 - Resultados da avaliação dos parâmetros do potencial de ação motor nos estudos de Moy et $\mathrm{al}^{17}$ e Inalöz et $\mathrm{al}^{27}$.

\begin{tabular}{|c|c|c|c|c|}
\hline PARÂMETRO & \multirow{2}{*}{ ESTUDO } & \multicolumn{3}{|c|}{ TIPO DE REPARO } \\
\cline { 3 - 5 } & & CONTROLE & SUTURA & ADESIVO \\
\hline \multirow{2}{*}{$\%$ da AMP } & \multirow{2}{*}{ Moy et al $^{17}$} & & $13 \%(6 \mathrm{sem})$. & $8 \%(6 \mathrm{sem})$. \\
\cline { 3 - 5 } & & & $24 \%(12 \mathrm{sem})$. & $19 \%(12 \mathrm{sem})$. \\
\hline LAT $(\mathrm{ms})$ & ${\text { Inalöz et } \mathrm{al}^{27}}^{27}$ & $1,45 \pm 0,14$ & $2,14 \pm 0,67$ & $1,95 \pm 0,64$ \\
\hline
\end{tabular}

Legenda: LAT: latência; ms: milissegundos; \% da AMP: porcentagem da amplitude final no nervo operado em relação à amplitude no nervo contralateral não operado; sem.: semanas.

Oito estudos na literatura avaliaram a histomorfometria dos nervos submetidos ao reparo com sutura, adesivo e/ou combinação das duas técnicas no nervo ciático do rato após a sua secção ${ }^{19,20,21,23,24,25,29,246}$. Apenas quatro estudos informaram sobre a contagem de axônios na região proximal e distal ao reparo, possibilitando o cálculo do IReg 20, 21, 24, 245. Nos estudos de Zhou ${ }^{25}$ e Zhang et al $^{29}$ o valor do IReg foi informado sem o valor do número de axônios no segmento proximal e distal. O diâmetro médio dos axônios foi descrito em três estudos ${ }^{20,23,246}$, sendo que em um deles esse dado foi avaliado apenas no segmento distal ${ }^{20}$. 
3. OBJETIVO 


\section{OBJETIVO}

Este estudo tem como objetivo comparar, através de parâmetros obtidos com a avaliação funcional, eletrofisiológica e histomorfométrica, a regeneração após secção do nervo ciático do rato e realização do reparo com a utilização de sutura, adesivo de fibrina ou uma combinação das duas técnicas. Essa comparação visa estabelecer qual deses métodos proporciona as melhores condições para a regeneração do nervo ciático do rato. 


\section{MÉTODOS}




\section{MÉTODOS}

A atividade experimental deste estudo foi realizada no período de 13 de dezembro de 2001 a 29 de julho de 2003 no Laboratório de Neurocirugia Experimental, LIM 45, na Faculdade de Medicina da Universidade de São Paulo. A análise dos resultados ocorreu no período de agosto de 2003 a julho de 2004 .

Para a realização deste trabalho foi elaborado protocolo onde todos os animais foram avaliados através do padrão da marcha previamente à exposição cirúrgica do nervo ciático direito.

Após a exposição cirúrgica e o isolamento do nervo foi realizada avaliação eletrofisiológica com medidas do PAN e do PAM. Em seguida o nervo foi seccionado e realizado reparo imediato do mesmo.

Após 12 semanas da intervenção cirúrgica, os animais foram submetidos à nova avaliação do padrão da marcha.

Decorridas 24 semanas do ato cirúrgico os animais foram reoperados com exposição dos nervos ciáticos previamente reparados e foi realizada nova avaliação eletrofisiológica.

Após essa avaliação os nervos foram fixados em solução de Karnovsky e seccionados para a retirada de segmentos que foram enviados para o Laboratório de Neurobiologia no Departamento de Biologia Celular e do Desenvolvimento do Instituto de Ciências Biomédicas da Universidade de São Paulo onde foram processados com a finalidade de se obter cortes histológicos para a realização da avaliação histomorfométrica. 
O tempo transcorrido entre as etapas dos procedimentos foi baseado em dados da literatura descritos no anexo A. A figura 2 demonstra a distribuição temporal dos procedimentos realizados.

Distribuição Temporal dos Procedimentos do Estudo

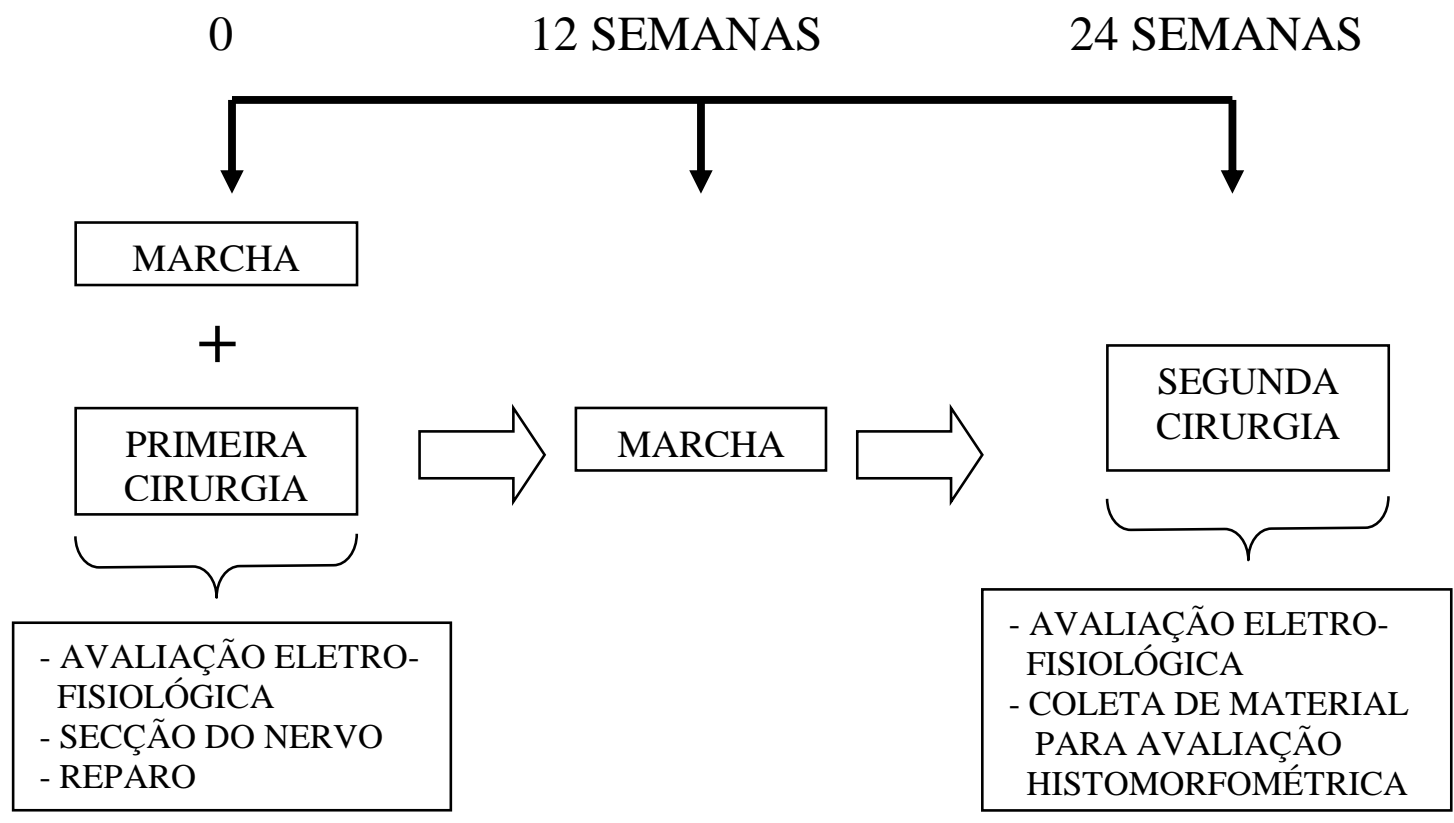

Figura 2 - Distribuição temporal dos procedimentos do estudo.

Para a realização deste trabalho foram utilizados oitenta e seis ratos Wistar machos com peso variando de 260 a 355 gramas (gr), originários do Centro de Bioterismo da Faculdade da Medicina da Universidade de São Paulo. O anexo B descreve o número de identificação do animal, a data da primeira e segunda cirurgia, o peso no momento desses procedimentos e o tipo de reparo adotado.

Previamente ao procedimento cirúrgico cada animal foi submetido à análise funcional da marcha com a finalidade de se verificar a integridade desse parâmetro. Esse estudo foi obtido com a análise das pegadas impressas pelas patas posteriores dos animais de acordo com o método previamente descrito por De Medinaceli et al ${ }^{167}$ e modificado por Bain et $\mathrm{al}^{168}$. 
As patas traseiras de cada animal foram imersas em tinta nanquim preta, permitindo-se que o rato caminhasse livremente ao longo de um corredor de madeira aberto em sua porção superior com $8,2 \mathrm{~cm}$ de largura por $42 \mathrm{~cm}$ de comprimento. Esse corredor era contínuo a um compartimento recoberto e escuro e seu assoalho revestido por cortiça de forma a permitir a fixação e a troca de papel sulfite branco (Figura 3).

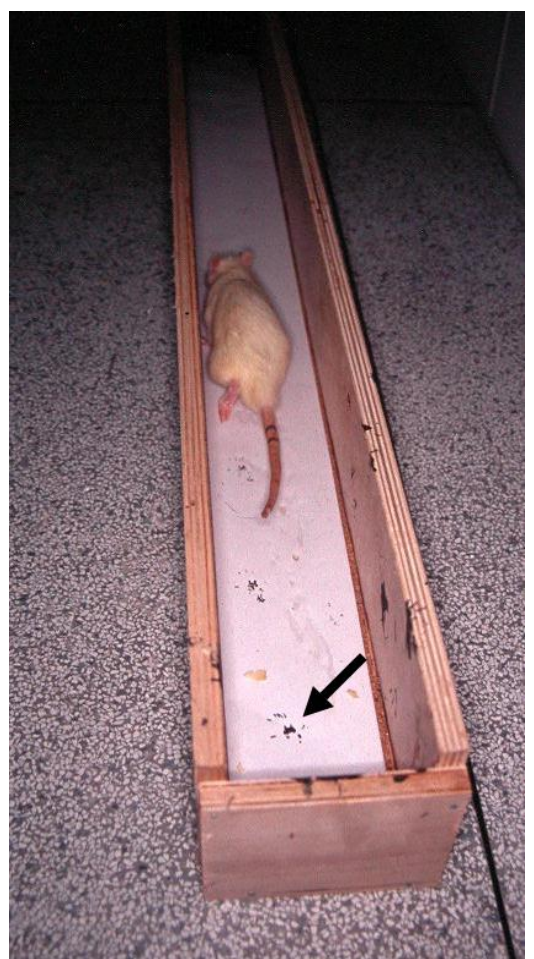

Figura 3 - Corredor utilizado na avaliação dos parâmetros da marcha contendo um animal e marcas das patas traseiras. A seta aponta para uma das marcas impressas.

Na maioria dos casos somente uma caminhada do animal foi suficiente para se obter impressões adequadas no papel. As impressões resultantes de uma caminhada interrompida pelo animal foram descartadas. Da análise das pegadas impressas no papel foram mensuradas três medidas, o comprimento da pegada definido pela distância do calcanhar à extremidade mais distal dos dedos (CP), a distância entre os dedos, medida entre o primeiro ao quinto dedo (DD) e a distância entre os dedos 
intermediários, correspondente à distância entre o segundo e o quarto dedos (DI) (Figura 4).

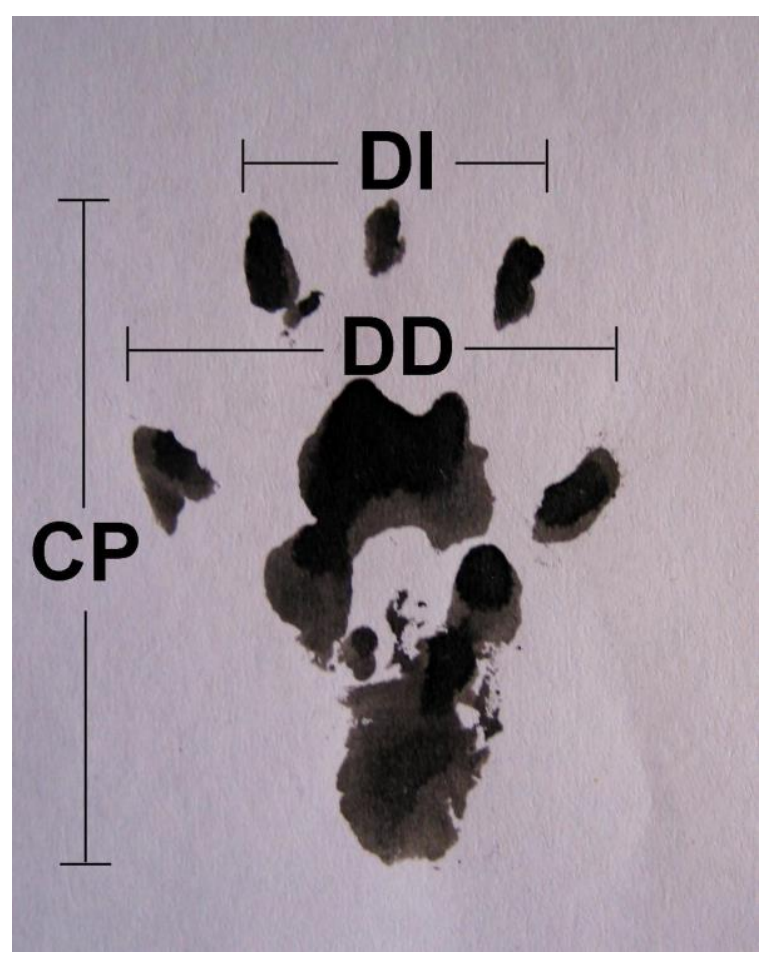

Figura 4 - Marca da pata traseira esquerda do rato com os parâmetros utilizados na avaliação do índice funcional ciático na fase pré-operatória.

Legenda: CP: comprimento da pegada; DD: distância entre os dedos; DI distância entre os dedos intermediários.

Com essas medidas efetuadas na pata esquerda e na pata direita foi calculado o índice funcional ciático (IFC) na fase pré-operatória (IFC1) com base na equação (1) formulada por Bain et $\mathrm{al}^{168}$.

Equação 1: fórmula de Bain et al ${ }^{168}$ aplicada para o cálculo do índice funcional ciático pré-operatório.

$\mathrm{IFC} 1=-38,3 \times[(\mathrm{CPD}-\mathrm{CPE}) / \mathrm{CPE}]+109,5 \times[(\mathrm{DDD}-\mathrm{DDE} / \mathrm{DDE})]+13,3 \times[(\mathrm{DID}-$ DIE/DIE) $]-8,8$

Legenda: CPD: comprimento da pegada da pata direita; CPE: comprimento da pegada da pata esquerda; DDD: distância entre os dedos da pata direita; DDE: distância entre os dedos da pata esquerda; DID: distância entre os dedos intermediários da pata direita; DIE: distância entre os dedos intermediários da pata esquerda; IFC1: índice funcional ciático pré-operatório. 
$\mathrm{Na}$ avaliação do IFC, zero é considerado como valor normal, mas variações de 11 pontos positivos ou negativos em torno desse valor podem ser observadas ${ }^{167}$. O valor considerado como a tradução de uma disfunção completa do nervo é $-100^{168}$.

Todas as medidas dos parâmetros utilizados no cálculo do IFC foram efetuadas pelo autor do estudo.

Após a avaliação do IFC1, os animais foram submetidos ao procedimento cirúrgico, sendo previamente anestesiados utilizando-se uma dose única de 0,1 mililitros (ml) de diazepam administrado por via intraperitoneal seguindo-se de cloridrato de ketamina, na dose de $0,2 \mathrm{ml}$ para cada $100 \mathrm{gr}$ do animal, também através de injeção intraperitoneal. Conforme a necessidade foram aplicadas doses suplementares de cloridrato de ketamina na dosagem de 0,1 a 0,2 ml.

Todo o procedimento cirúrgico foi realizado no interior de uma gaiola de Faraday a fim de se reduzir eventuais interferências eletromagnéticas durante a fase de avaliação eletrofisiológica. Após a anestesia os animais foram posicionados em decúbito ventral e submetidos à tricotomia da região dorso-caudal direita. Após assepsia com álcool a 70 graus, foi realizada uma incisão longitudinal que incluiu a pele e o tecido subcutâneo*. Esta incisão iniciava-se a $0,5 \mathrm{~cm}$ lateral à linha média do animal e dirigia-se lateralmente numa extensão de três $\mathrm{cm}$ em direção à articulação tíbio-femoral. Com dissecção romba os músculos bíceps femoral e glúteo foram afastados, permitindo o acesso ao nervo ciático desde a origem até as suas divisões (Figura 5).

* Parte do material cirúrgico utilizado neste estudo foi fornecido pela Codman, divisão da Johnson \& Johnson Produtos Profissionais LTDA. 


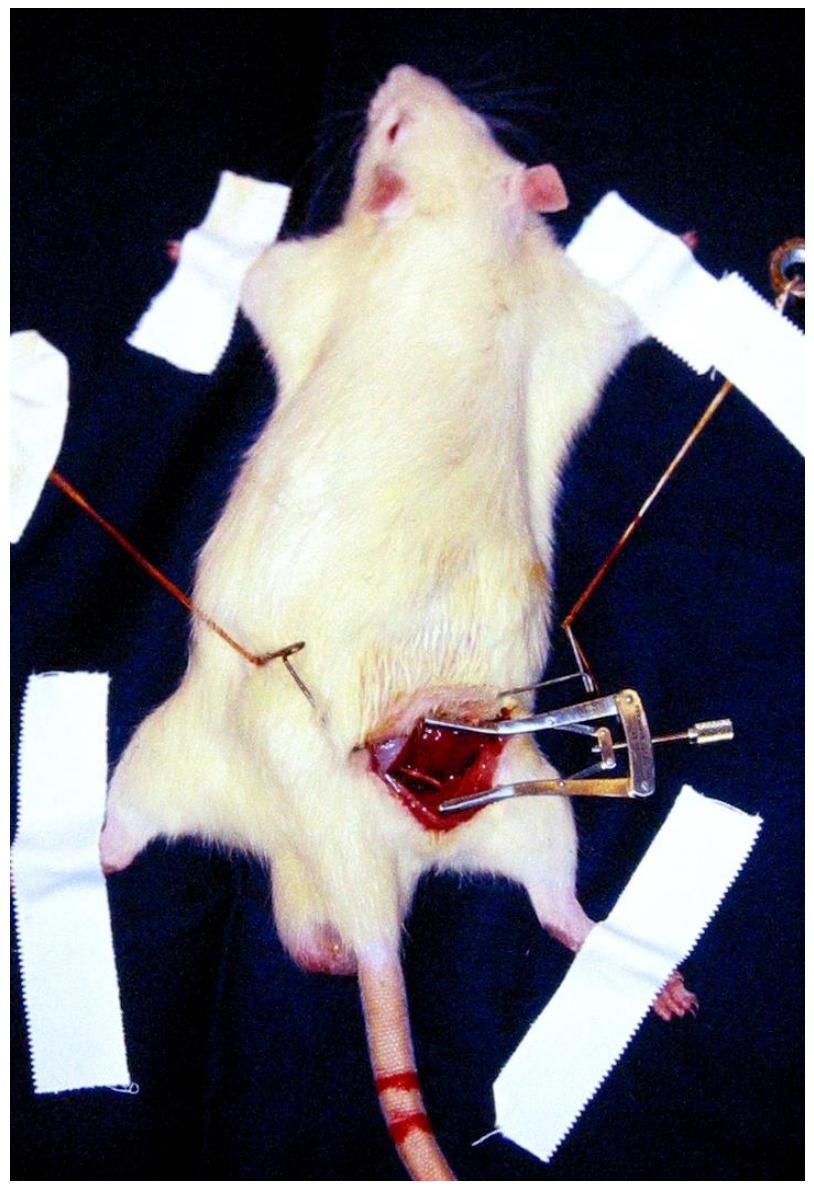

Figura 5 - Exposição cirúrgica do nervo ciático direito do rato.

Após a exposição do nervo, procedeu-se à realização da avaliação eletrofisiológica que tinha como objetivos verificar a integridade dos nervos e estabelecer um parâmetro eletrofisiológico de normalidade para cada animal. Para essa avaliação foram desenvolvidos dois eletrodos do tipo terra, um eletrodo para estímulo e outro para registro do PAN, um eletrodo para estímulo e outro para registro do PAM.

Um dos eletrodos utilizado para o aterramento foi confeccionado em arame de aço inox $316 \mathrm{~L}^{*}$ de $0,40 \mathrm{~mm}$ de diâmetro com extremidade em formato helicoidal que era posicionado de forma a envolver o nervo, aumentando a área de contato (Figura 6). O outro eletrodo tipo terra consistia de uma agulha monopolar com diâmetro 
de 0,40 $\mathrm{mm}$ por $25 \mathrm{~mm}$ de comprimento com gauge $(\mathrm{G}) 26^{*}$ cuja extremidade reta era posicionada, através de punção, no interior da musculatura adjacente ao nervo (Figura 6 e 7).

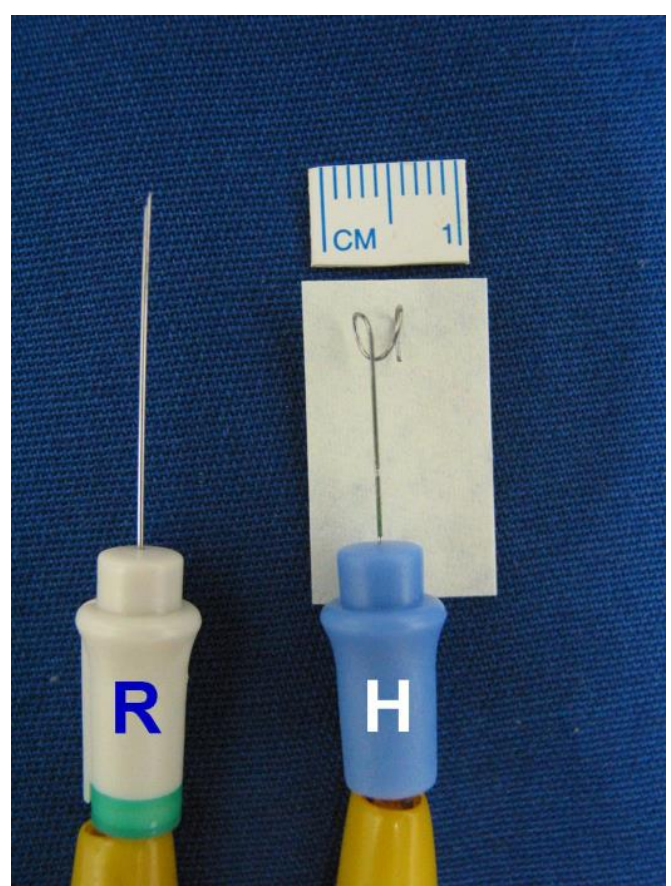

Figura 6 - Eletrodos do tipo terra modelo reto $(\mathrm{R})$ e helicoidal $(\mathrm{H})$. Legenda: H: eletrodo helicoidal; R: eletrodo reto.

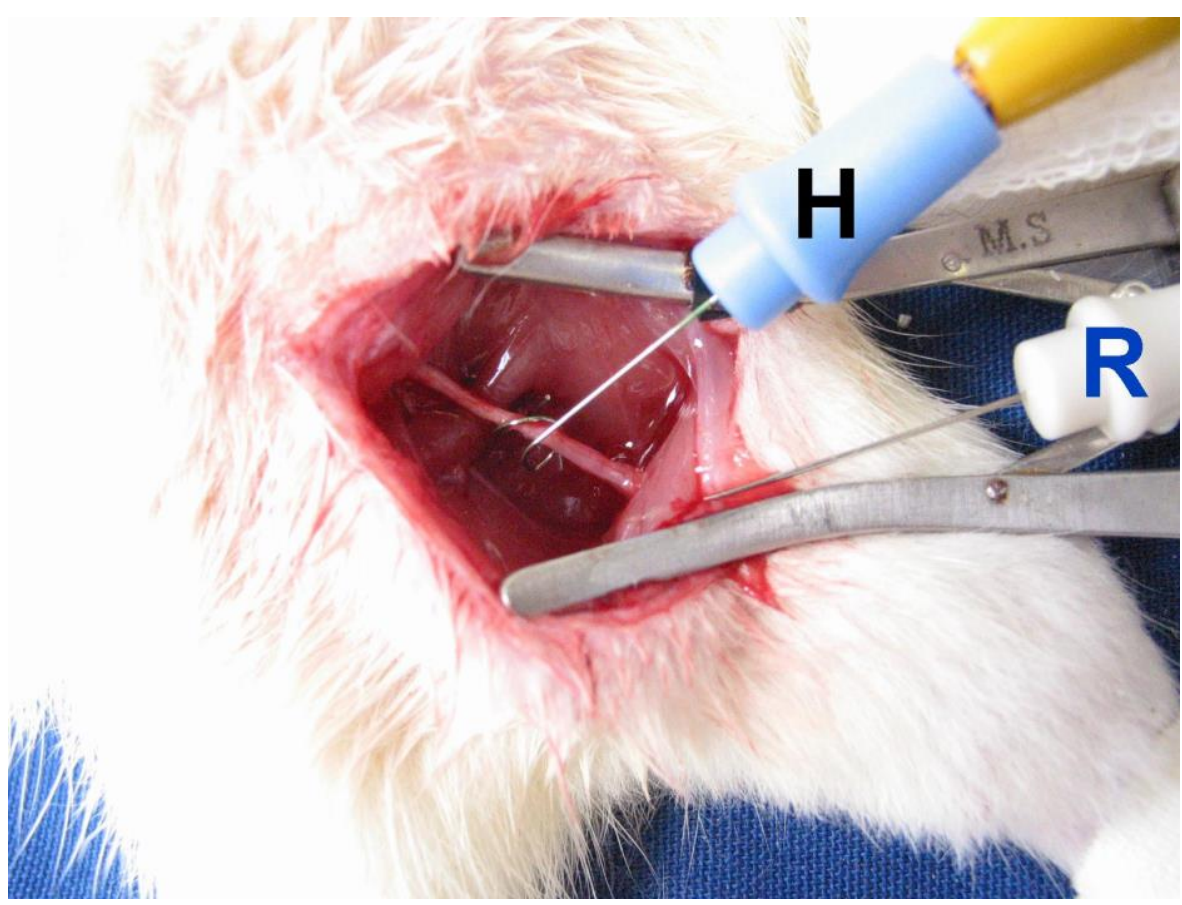

Figura - 7: Foto cirúrgica realizada após exposição do nervo ciático com instalação dos dois eletrodos do tipo terra, um com extremidade helicoidal $(\mathrm{H})$ que envolve o nervo e outro com extremidade reta $(\mathrm{R})$ inserido na musculatura adjacente.

Legenda: H: eletrodo helicoidal; R: eletrodo reto. 
Os eletrodos de estímulo e de registro do PAN foram confeccionados em arame de aço inox 316L de 0,5 mm de diâmetro, separados por uma distância de um mm do ânodo para o cátodo.

Para o registro do PAM foi utilizada uma agulha coaxial com $0,30 \mathrm{~mm}$ de diâmetro por $25 \mathrm{~mm}$ de comprimento com $30 \mathrm{G}^{*}$ e área de registro de $0,019 \mathrm{~mm}$ quadrados.

Os registros foram realizados com um eletroneuromiógrafo portátil de dois

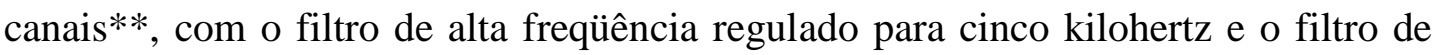
baixa freqüência regulado para dois hertz, com pulso elétrico retangular monofásico regulado para a largura de $0,04 \mathrm{~ms}$ com a finalidade de reduzir os artefatos desencadeados pelo estímulo. A velocidade de varredura horizontal foi ajustada à taxa de 0,5 ms por divisão e o ganho vertical à taxa de cinco $\mathrm{mV}$ por divisão.

Após a exposição do nervo ciático foram instalados os eletrodos do tipo terra, o do tipo helicoidal a meia distância dos eletrodos de estímulo e de registro. Os eletrodos de estímulo e registro foram posicionados na extremidade proximal e distal do nervo, respectivamente, separados por um intervalo de $20 \mathrm{~mm}$ (Figura 8). 


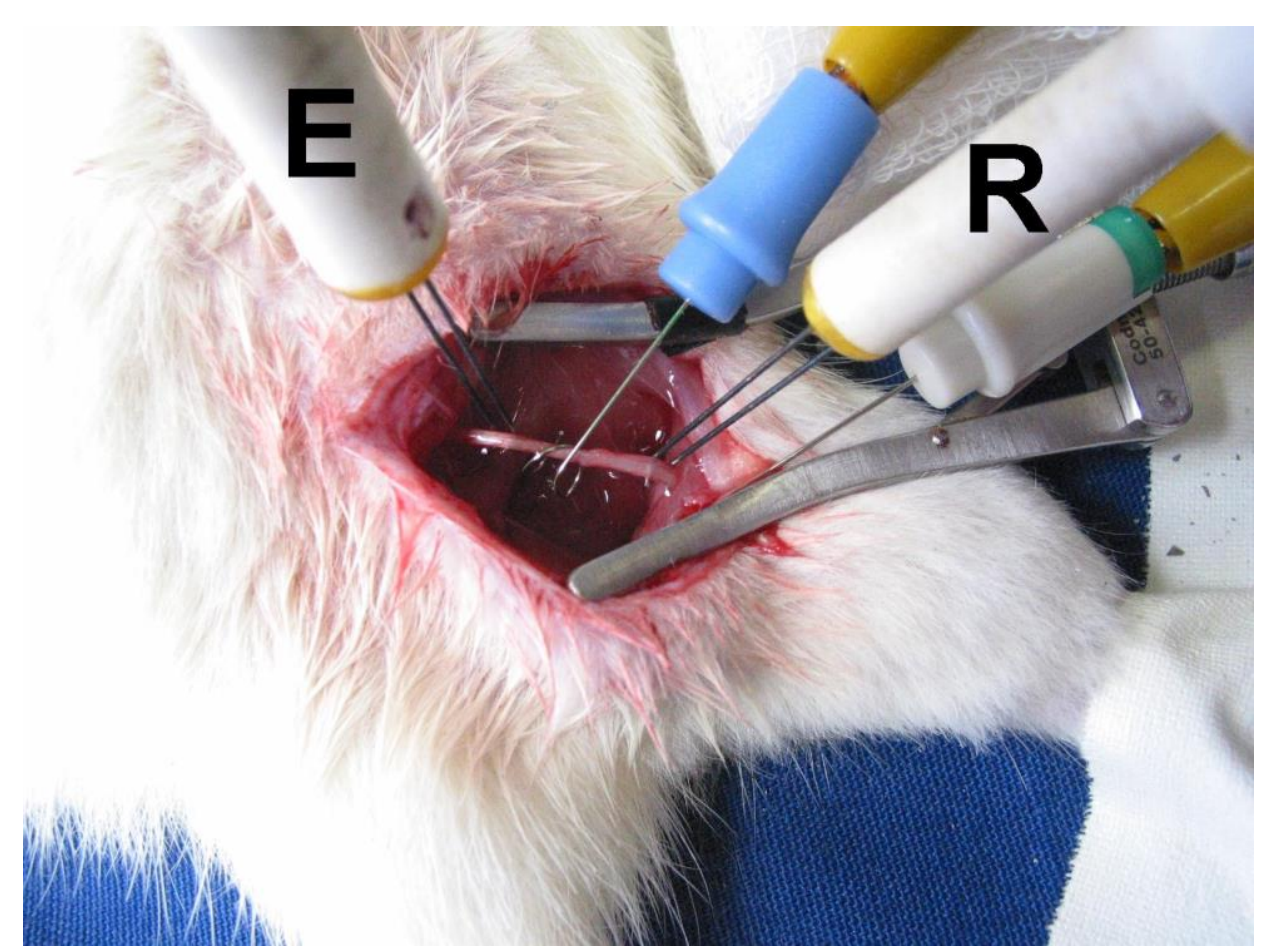

Figura 8 - Fotografia realizada durante a mensuração do potencial de ação do nervo, que mostra o posicionamento dos eletrodos de estímulo (E) e registro (R). Legenda: E: eletrodo de estímulo; R: eletrodo de registro.

Foram aplicados estímulos supramáximos de curta duração (um ms) para gerar um potencial de ação no nervo. Para se determinar essa corrente supramáxima de estimulação a corrente de estímulo era aumentada gradativamente, de 0,1 a 0,1 miliampère (mA), até que a amplitude dos dois últimos potenciais se mantivesse inalterada. A partir do registro desse potencial, denominado potencial de ação do nervo pré-operatório (PAN1), foram medidas a latência e a amplitude máxima do mesmo denominados respectivamente de LATN1 e AMPN1. A velocidade de condução do PAN foi determinada dividindo-se a latência pela distância de $20 \mathrm{~mm}$ entre os eletrodos e denominada VCN1.

Após a avaliação do PAN1 procedeu-se à mensuração do PAM denominado de potencial de ação motor pré-operatório (PAM1). O eletrodo de registro distal foi retirado mantendo-se os eletrodos terra e de estímulo na mesma posição da descrita 
para o registro do PAN1. O eletrodo de registro foi instalado no músculo gastrocnêmio através de punção percutânea com agulha coaxial a partir do terço distal da pata ipsilateral ao procedimento cirúrgico(Figura 9). A distância entre o eletrodo de estímulo e o de registro foi de $30 \mathrm{~mm}$.

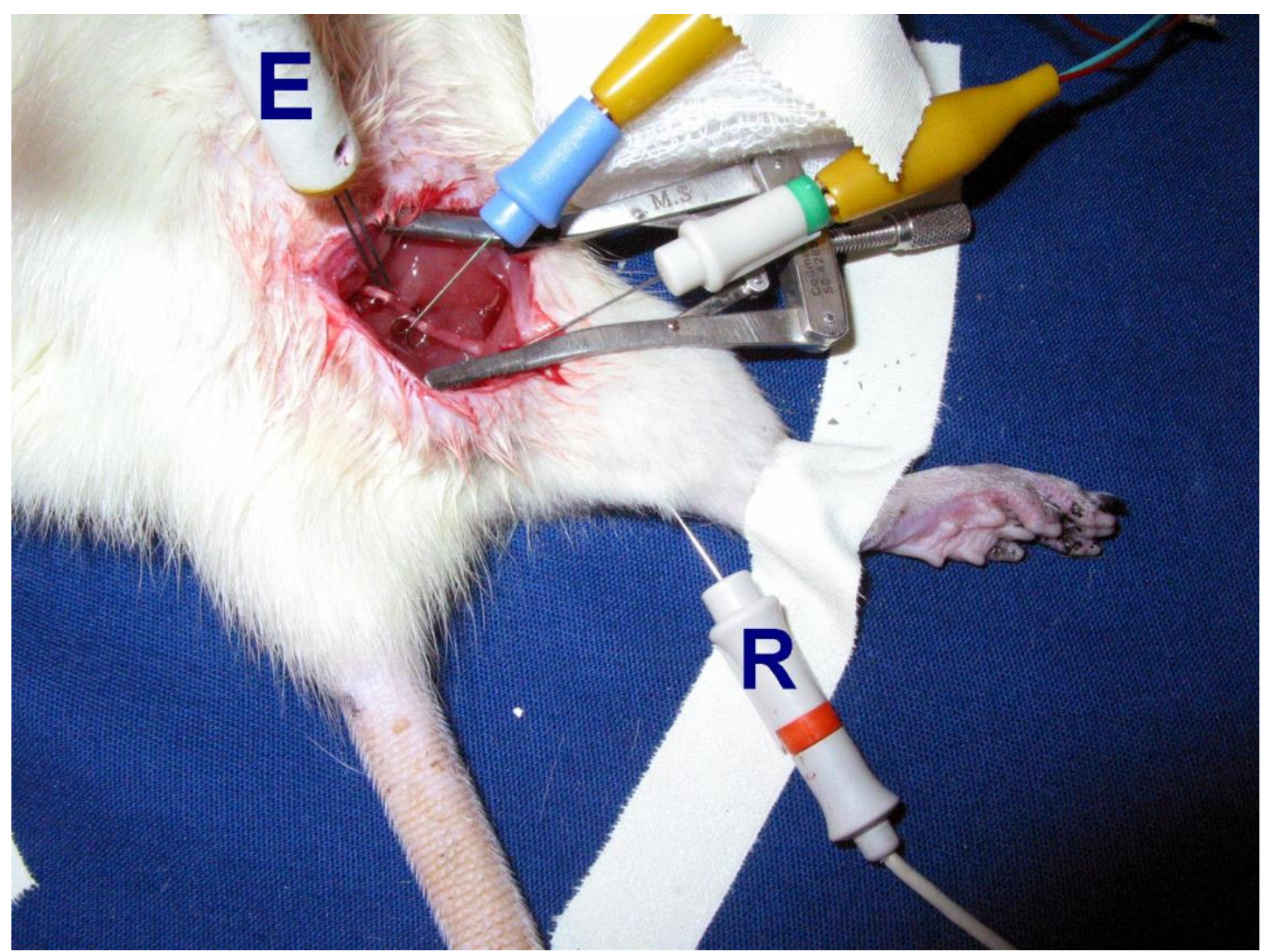

Figura 9 - Fotografia cirúrgica realizada durante a avaliação do potencial de ação motor, que evidencia o posicionamento do eletrodo de estímulo (E) e do eletrodo de registro $(\mathrm{R})$, esse instalado no músculo gastrocnêmio através de punção percutânea. Legenda: E: eletrodo de estímulo; R: eletrodo de registro.

Foram aplicados estímulos supramáximos de curta duração (um ms) para gerar um potencial de ação motor. Para se determinar essa corrente supramáxima de estimulação, a corrente de estímulo foi aumentada gradativamente, de 0,1 a 0,1 mA, até que a amplitude dos dois últimos estímulos se mantivesse inalterada. A partir do registro deste potencial foram medidas a latência e a amplitude do PAM1, 
denominados, respectivamente, de LATM1 e AMPM1. Com a divisão da latência pela distância entre os eletrodos foi determinada a velocidade de condução do PAM1 nomeado VCM1.

Todos os registros eletrofisiológicos foram realizados pelo autor deste estudo. Os resultados dessa avaliação foram analisados por um investigador independente*.

Após avaliação eletrofisiológica, utilizando-se técnica microcirúrgica e magnificação de 25 vezes**, foi realizada a secção total e uniforme do nervo ciático com tesoura microcirúrgica na metade da distância entre sua origem e a sua primeira divisão (Figura 10). Após essa secção procedeu-se ao reparo imediato. Nesta etapa da cirurgia o procedimento foi realizado com o auxílio do microscópio em aumento de quarenta vezes.

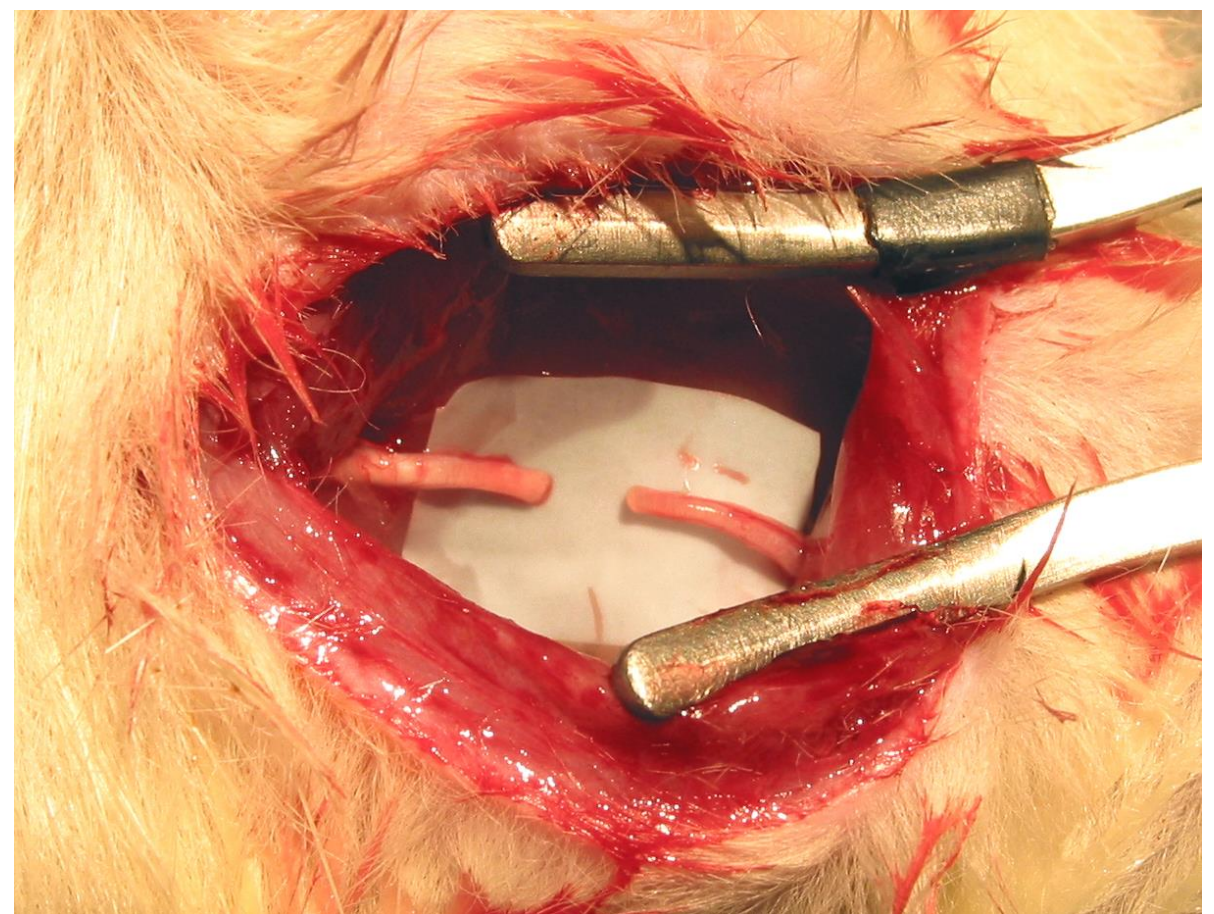

Figura 10 - Fotografia realizada durante o procedimento cirúrgico que evidencia o nervo ciático após sua secção. 
Três grupos de animais denominados A, B e C, foram formados ao acaso de acordo com a técnica de reparo empregada. Foi computada a perda de 56 animais devido à ocorrência de óbitos durante a anestesia, no período pós-operatório e na evolução e devido ao sacrifício pela presença de complicações relacionadas à cirurgia, que consistiram de lesões secundárias à autotomia (Figura 11) e de retrações músculo-tendíneas na pata ipsilateral ao procedimento cirúrgico (Figura 12). O número de espécimes operados nos grupos $\mathrm{A}, \mathrm{B}$ e $\mathrm{C}$ para que se atingisse o número final de 10 animais em cada grupo foi, respectivamente, 34, 29 e 23.

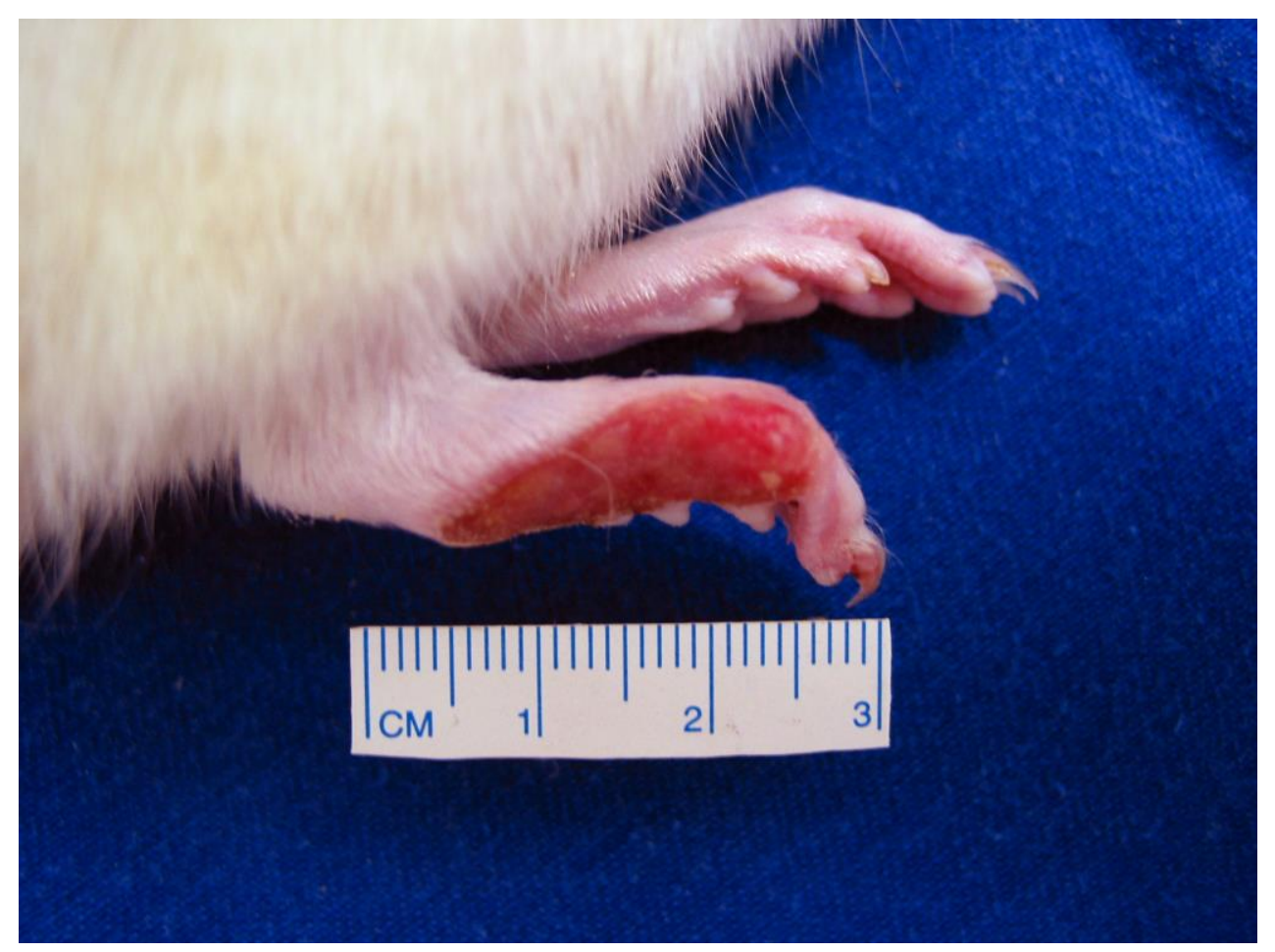

Figura 11 - Fotografia da pata direita de animal portador de grave lesão secundária à autotomia.

Legenda: cm: centímetro. 


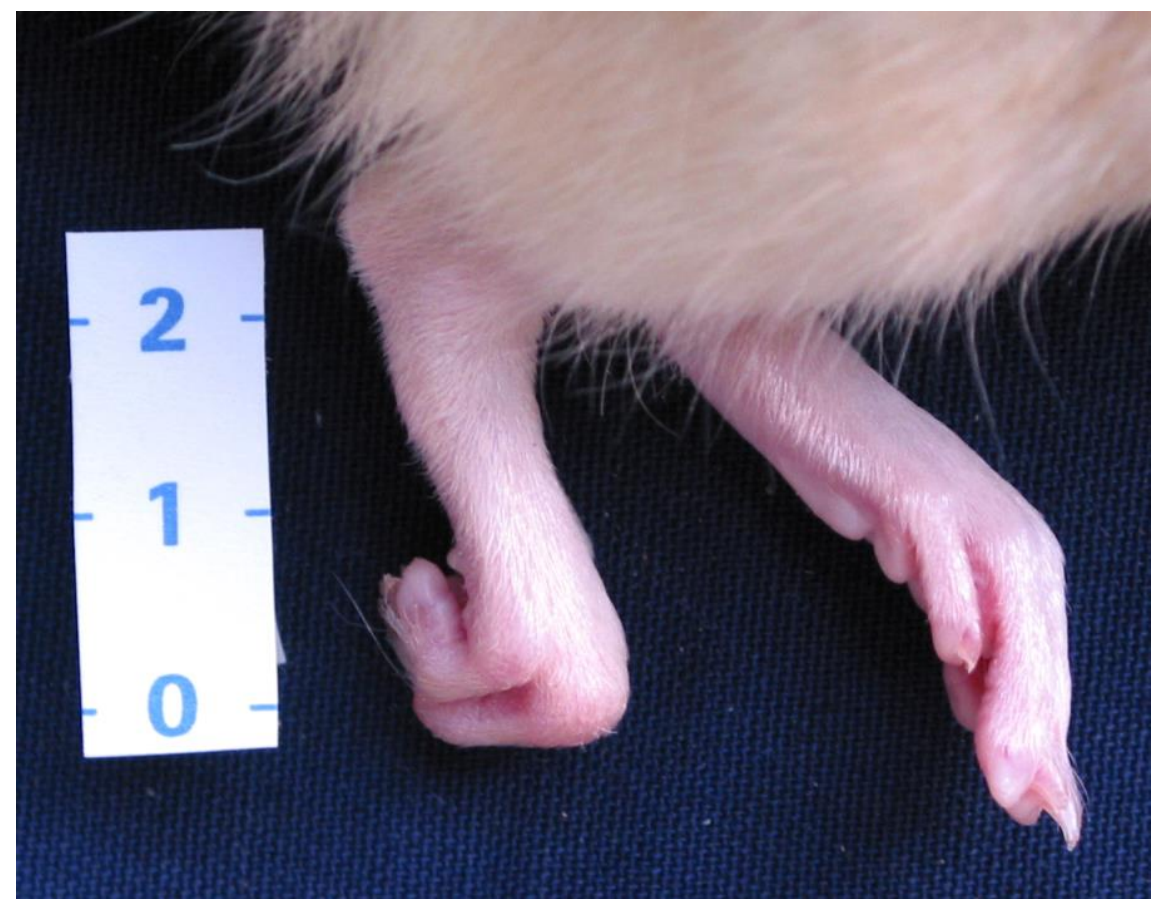

Figura 12 - Fotografia da pata direita do animal que mostra postura em flexão dos dedos secundária à retração músculo-tendínea.

A tabela 4 relaciona o número de animais que morreram, quantos foram sacrificados devido à autotomia e quantos foram sacrificados devido a retrações músculo-tendíneas para que se atingisse o número de 10 animais em cada grupo de reparo.

Tabela 4 - Número de animais que morreram, quantos foram sacrificados devido à autotomia e quantos foram sacrificados devido a retrações músculo-tendíneas.

\begin{tabular}{|c||c|c|c|c|}
\hline & SUTURA & ADESIVO & $\begin{array}{c}\text { ADESIVO E } \\
\text { SUTURA }\end{array}$ & TOTAL \\
\hline \hline ÓBITOS & $2(6 \%)$ & $3(10,4 \%)$ & $5(21,7 \%)$ & $10(11,7 \%)$ \\
\hline SACRIFICADOS 1 & $12(35 \%)$ & $12(41,3 \%)$ & $5(21,7 \%)$ & $29(33,7 \%)$ \\
\hline SACRIFICADOS 2 & $10(29,5 \%)$ & $4(13,8 \%)$ & $3(13,1 \%)$ & $17(19,7 \%)$ \\
\hline SOBREVIVENTES & $10(29,5 \%)$ & $10(34,5 \%)$ & $10(43,5 \%)$ & $30(34,9 \%)$ \\
\hline \hline TOTAL & $34(100 \%)$ & $29(100 \%)$ & $23(100 \%)$ & $86(100 \%)$ \\
\hline
\end{tabular}

Legenda: ÓBITOS: óbitos ocorridos durante a anestesia ou na evolução; SACRIFICADOS 1: número de animais sacrificados devido à autotomia; SACRIFICADOS 2: número de animais sacrificados devido a retrações músculotendíneas; SOBREVIVENTES: animais que completaram o período de observação. 
No grupo A, o reparo foi realizado através de sutura término-terminal com quatro pontos separados equidistantes de fio 10-0 de náilon monofilamentar com agulha cilíndrica de $70 \mu \mathrm{m}$ de diâmetro* (Figura 13).
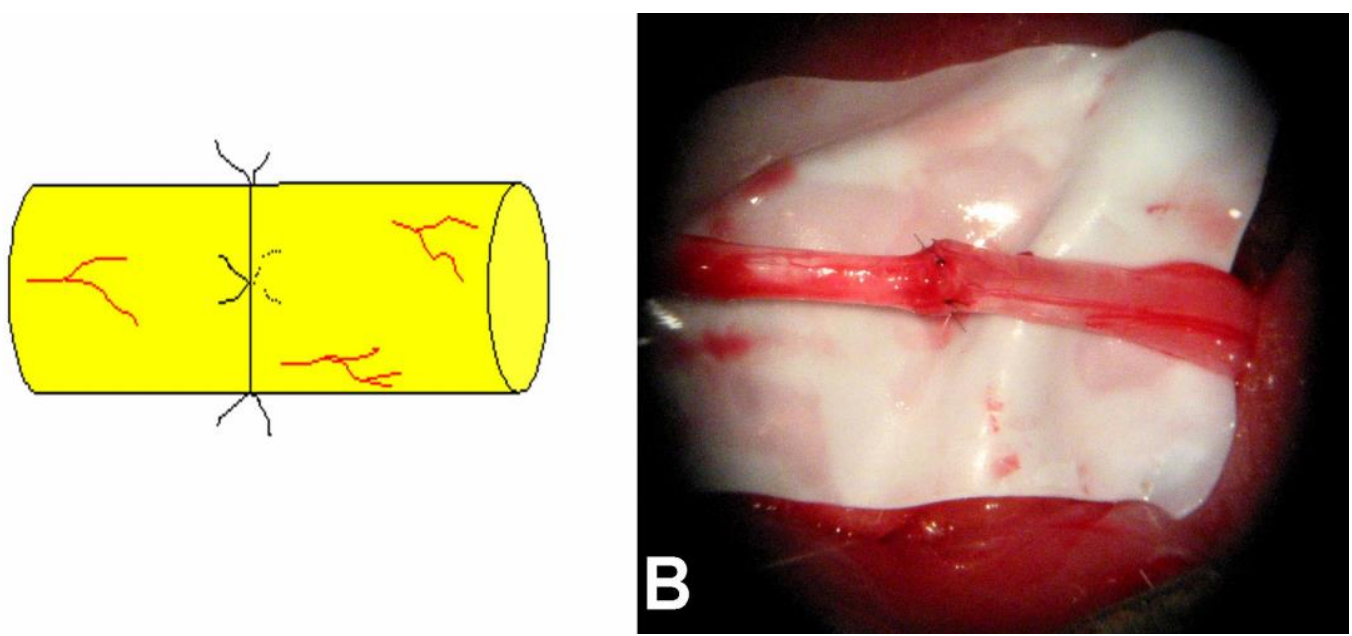

Figura 13 - Reparo com a sutura convencional. A - esquema que mostra o posicionamento dos pontos de fio de náilon. $\mathrm{B}$ - foto cirúrgica que evidencia o reparo com sutura do nervo ciático.

Após o reparo, os músculos foram aproximados com pontos separados de náilon monofilamentar 5-0 e a pele suturada com pontos separados de algodão 2-0.

Nesse grupo 34 animais foram submetidos à cirurgia. Destes, dois animais morreram no período pós-operatório, 12 animais desenvolveram lesões nas patas operadas secundárias à autotomia e 10 animais apresentaram complicações relacionadas à regeneração inadequada produzindo retrações músculo-tendíneas nas patas, que impediram a realização do teste da marcha. Os animais que apresentaram essas complicações necessitaram ser sacrificados com injeção intraperitoneal de pentobarbital sódico em alta dose.

No grupo $\mathrm{B}$ foi utilizado um adesivo à base de fibrina**. Esse material é constituído por dois frascos com produtos liofilizados, um deles contendo fibrinogênio e fator XIII e outro trombina; e dois frascos com produtos solúveis,

* B/Braun, Aesculap

** Beriplast ${ }^{\circledR}$, Aventis 
um dos quais contendo solução de aprotinina e outro com solução de cloreto de cálcio. Cada um $\mathrm{ml}$ do produto final contém 65 a $115 \mathrm{mg}$ de fibrinogênio, 40 a 80 unidades de fator XIII, 1000 unidades inibidoras de calicreína de aprotinina de pulmão bovino, 400 a 600 unidades internacionais de trombina e 5,88 $\mathrm{mg}$ de cloreto de cálcio*. No momento do uso, os componentes liofilizados foram misturados aos solúveis, o fibrinogênio e o fator XIII à solução de aprotinina e a trombina à solução de cloreto de cálcio. Os resultados dessas combinações foram aspirados em seringas apropriadas e misturados no momento do reparo.

Utilizando-se o adesivo para o reparo, os dois cotos dos nervos foram mantidos em oposição através da aplicação de uma micropinça entre os epineuros, sobre os quais foi instilada uma gotícula do adesivo com agulha específica que acompanha o produto (Figura 14). Após três minutos o mesmo processo foi repetido em local diametralmente oposto à aplicação da primeira gotícula. $\mathrm{O}$ mesmo período de tempo foi aguardado até que se retirasse novamente a pinça.
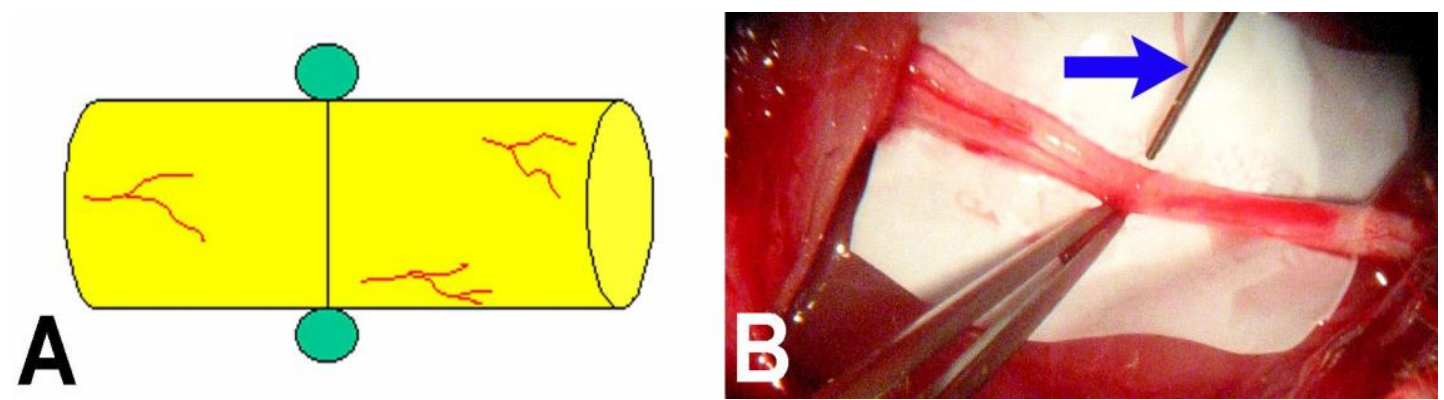

Figura 14 - Reparo com o adesivo de fibrina. A - Esquema que demonstra a aplicação do adesivo. B - Foto microcirúrgica que evidencia os dois cotos do nervo ciático mantidos em oposição através da aplicação de uma micropinça e agulha (seta azul) contendo o adesivo a ser aplicado na área do reparo.

* Para cada lote do produto há um certificado de análise com testes e resultados obtidos que acompanha o processo de importação do mesmo. A especificação garante que a concentração nessa faixa está dentro dos níveis terapêuticos exigidos e esperados. 
Após o reparo, os músculos foram aproximados com pontos separados de náilon monofilamentar 5-0 e a pele suturada com pontos separados de algodão 2-0. No grupo B 29 animais foram submetidos à cirurgia. Desses, três animais morreram no período pós-operatório, 12 animais desenvolveram lesões nas patas operadas secundárias à autotomia e quatro animais apresentaram retrações músculo-tendíneas nas patas que impediram a realização do teste da marcha. Os animais que apresentaram essas complicações necessitaram ser sacrificados com injeção intraperitoneal de pentobarbital sódico em alta dose.

No grupo C o reparo foi realizado através da combinação das duas técnicas e consistiu na realização de um ponto de náilon 10-0 monofilamentar do mesmo tipo utilizado no grupo A entre os epineuros dos cotos do nervo associado à aplicação de uma gotícula do adesivo de fibrina em local diametralmente oposto ao ponto e com o mesmo processo descrito no grupo B (Figura 15).

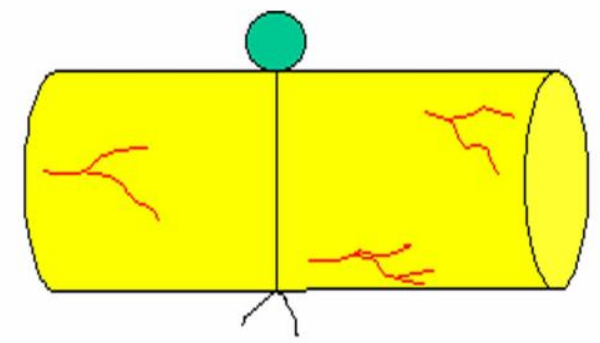

A

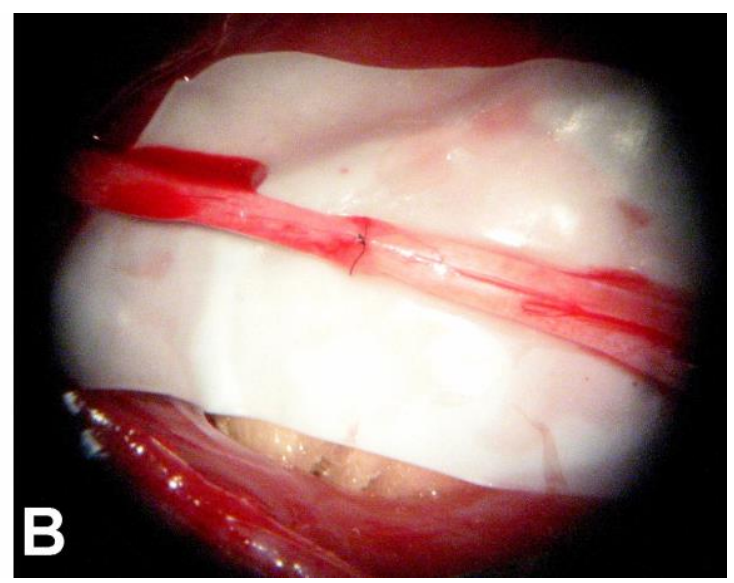

Figura 15 - Reparo com a combinação das duas técnicas. A - Esquema que evidencia a aplicação do adesivo de fibrina em local oposto à realização de um ponto. $\mathrm{B}$ - Foto microcirúrgica que mostra o ponto único do reparo com a utilização das duas técnicas.

Após o reparo, o fechamento foi realizado de forma semelhante à descrita nos grupos A e B. 
No grupo C 23 animais foram submetidos à cirurgia. Desses, cinco animais morreram no período pós-operatório, cinco animais desenvolveram lesões nas patas operadas secundárias à autotomia e três animais apresentaram retrações músculotendíneas nas patas que impediram a realização do teste da marcha. Os animais que apresentaram essas complicações necessitaram ser sacrificados com injeção intraperitoneal de pentobarbital sódico em alta dose.

Todos os reparos foram realizados pelo autor do trabalho.

No período pós-operatório cada animal foi mantido em gaiola separada com água e ração ad libitum e numerado cardinalmente de forma que o examinador não tivesse conhecimento do tipo de reparo a que cada animal havia sido submetido.

Neste estudo, o alto índice de perda de animais em conseqüência da ocorrência de autotomia motivou o uso de uma proteção para a pata direita, na tentativa de se evitar esse tipo de comportamento e suas conseqüências. A partir do grupo de animais operados em 25 de abril de 2002, foi utilizada uma proteção que consistia de um enfaixamento da pata com algodão revestido por esparadrapo e embebido por pimenta vermelha (Figura 16). Essa proteção era trocada semanalmente até o segundo mês do período pós-operatório ou quando a mesma era retirada pelo animal. Com o uso da proteção, a perda por autotomia, que até a data da introdução deste procedimento era de $38,7 \%$ dos animais operados, caiu para $24,3 \%$. 


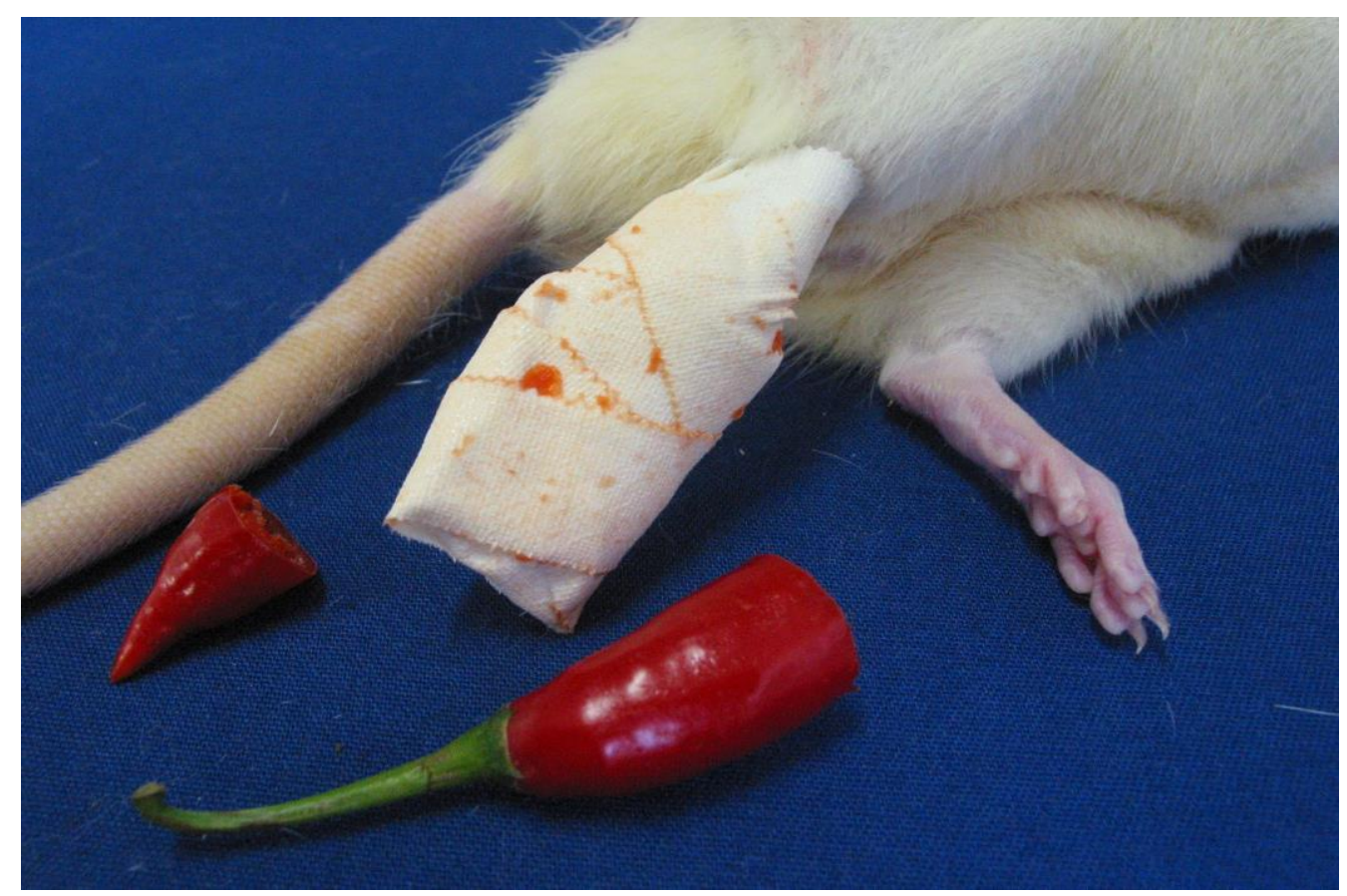

Figura 16 - Fotografia da região dorso-lateral de animal operado cuja pata direita foi envolvida por proteção constituída por enfaixamento realizado com algodão seguido de esparadrapo. Sobre a proteção foi aplicada pimenta vermelha.

Transcorridas 12 semanas do procedimento cirúrgico, os animais sobreviventes foram submetidos à avaliação funcional da marcha de maneira semelhante à realizada na fase pré-operatória. Com os parâmetros obtidos das marcas das patas traseiras dos animais (Figura 17) foi calculado o IFC denominado IFC pós-operatório ou IFC2 de acordo com a equação (2) formulada por Bain et al ${ }^{168}$.

Equação 2: fórmula de Bain et al ${ }^{168}$ aplicada para o cálculo do índice funcional ciático pós-operatório.

$\mathrm{IFC} 2=-38.3 \times[(\mathrm{CPO}-\mathrm{CPN}) / \mathrm{CPN}]+109.5 \times[(\mathrm{DDO}-\mathrm{DDN} / \mathrm{DDN})]+13.3 \times[(\mathrm{DIO}-$ DIN/DIN)] -8.8

Legenda: CPO: comprimento da pegada da pata no lado operado; CPN: comprimento da pegada da pata no lado não operado; DDO: distância entre os dedos da pata no lado operado; DDN: distância entre os dedos da pata no lado não operado; DIO: distância entre os dedos intermediários da pata no lado operado; DIN: distância entre os dedos intermediários da pata no lado não operado; IFC2: índice funcional ciático pós-operatório. 


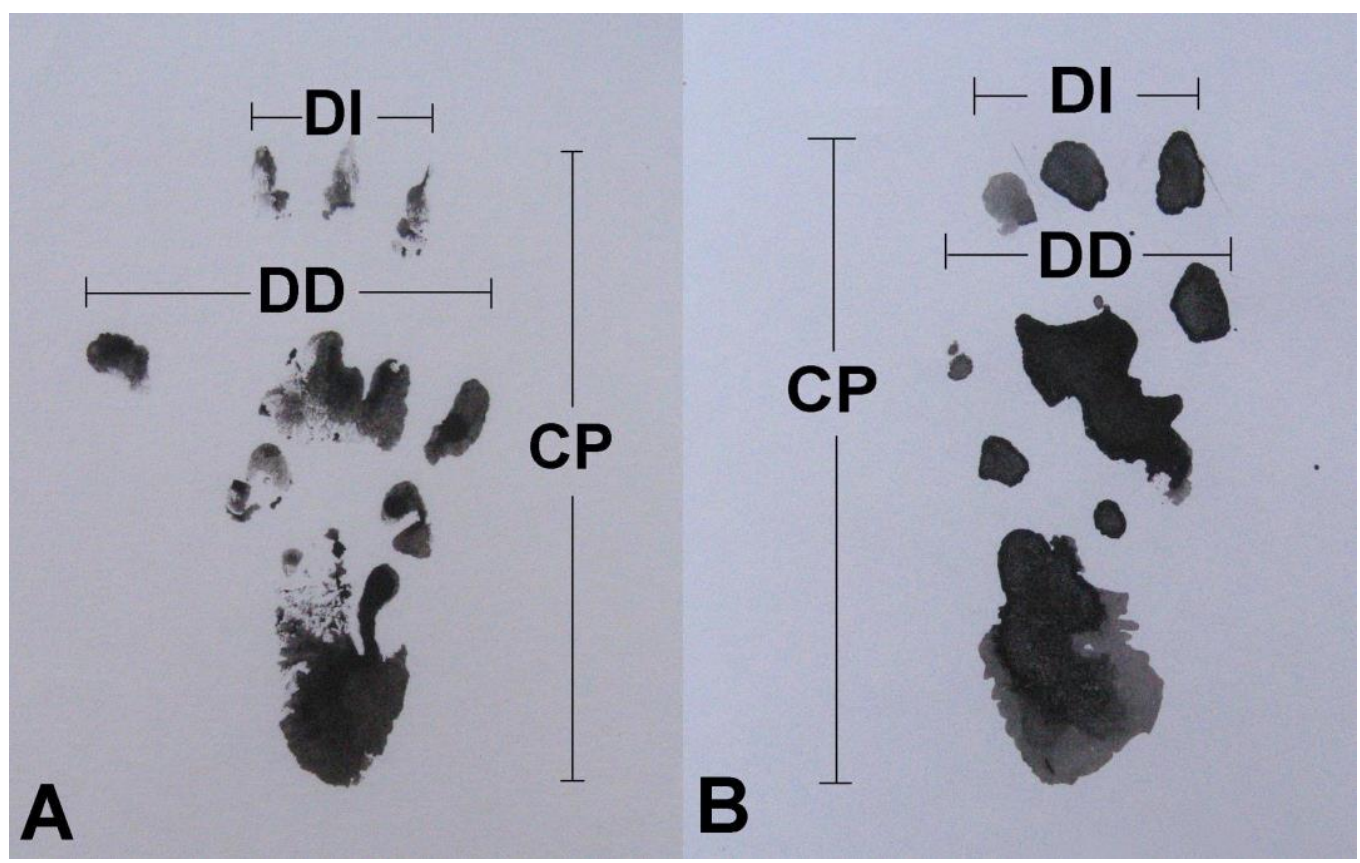

Figura 17 - Marcas das patas traseiras com os parâmetros para o cálculo do índice funcional ciático pós-operatório. A - marca da pata do lado não operado; B - marca da pata do lado operado.

Legenda: CP: comprimento da pegada; DD: distância entre os dedos; DI: distância entre os dedos intermediários.

A avaliação da regeneração, baseada no cálculo do IFC2, comparou os valores desse parâmetro nos três diferentes grupos de reparo. O investigador só tinha acesso à numeração do animal, o que impedia a identificação do grupo de reparo ao qual cada animal pertencia.

Após 24 semanas do procedimento cirúrgico, os animais foram submetidos à nova anestesia utilizando-se uma dose única de $0,2 \mathrm{ml}$ de diazepam administrado por via intraperitoneal seguindo-se de cloridrato de ketamina, na dose de 0,2 ml para cada 100 gr do animal, também através de injeção intraperitoneal. Conforme a necessidade, foram aplicadas doses suplementares de cloridrato de ketamina na dosagem de 0,3 a 0,4 $\mathrm{ml}$. O peso dos animais, no momento da segunda cirurgia, variou de 390 a 585 gr e constam no anexo B. 
Após a anestesia os animais foram posicionados em decúbito ventral sobre a mesa cirúrgica e submetidos à tricotomia da região dorso-caudal da pata direita. Após assepsia com álcool a 70 graus, foi realizada uma reincisão longitudinal na mesma topografia da incisão anterior que incluiu a pele e o tecido subcutâneo. Após a secção dos pontos que os uniam, os músculos bíceps femoral e glúteo foram afastados permitindo o acesso ao nervo ciático desde a sua origem até a sua primeira divisão.

Neste estudo não foi identificada a ocorrência de deiscência ou de neuroma no local do reparo.

Com a utilização de técnica microcirúrgica, os nervos foram dissecados e liberados de aderências com os tecidos vizinhos. Após a realização deste procedimento, procedeu-se à avaliação eletrofisiológica utilizando-se o mesmo protocolo da avaliação pré-operatória, obtendo-se os valores da latência e amplitude dos PAN e PAM. Os potenciais obtidos nesta fase foram denominados de PAN2 e PAM2. A latência e a amplitude do PAN2 foram denominadas de LATN2 e AMPN2, respectivamente. A latência e amplitude do PAM2 foram denominadas de LATM2 e AMPM2, respectivamente. As velocidades de condução do PAN2 e do PAM2 foram obtidas dividindo-se a latência pela distância entre os eletrodos de estímulo e registro e denominadas de VCN2 e VCM2, respectivamente.

Obtidos os valores dos parâmetros descritos no PAN2 e PAM2, foi calculada a porcentagem destes em relação ao valor inicial, para cada animal, definindo-se a porcentagem da amplitude do PAN em relação ao valor inicial (\%AMPN), a porcentagem da VC do PAN em relação ao valor inicial (\%VCN), a porcentagem da amplitude do PAM em relação ao valor inicial (\%AMPM) e a porcentagem da VC do 
PAM em relação ao valor inicial (\%VCM). A avaliação da regeneração, baseada nos parâmetros eletrofisiológicos, foi realizada comparando-se os valores da LATN2, AMPN2, VCN2, \%AMPN, \%VCN, LATM2, AMPM2, VCM2, \%AMPM e a $\%$ VCM.

Após a avaliação eletrofisiológica, os nervos ciáticos foram fixados in vivo com solução fixadora de Karnovsky constituída por $1 \%$ de paraformaldeído em associação com $2 \%$ de glutaraldeído em tampão fosfato de sódio a 0,1 molar e pH de 7,3 (Figura 18).

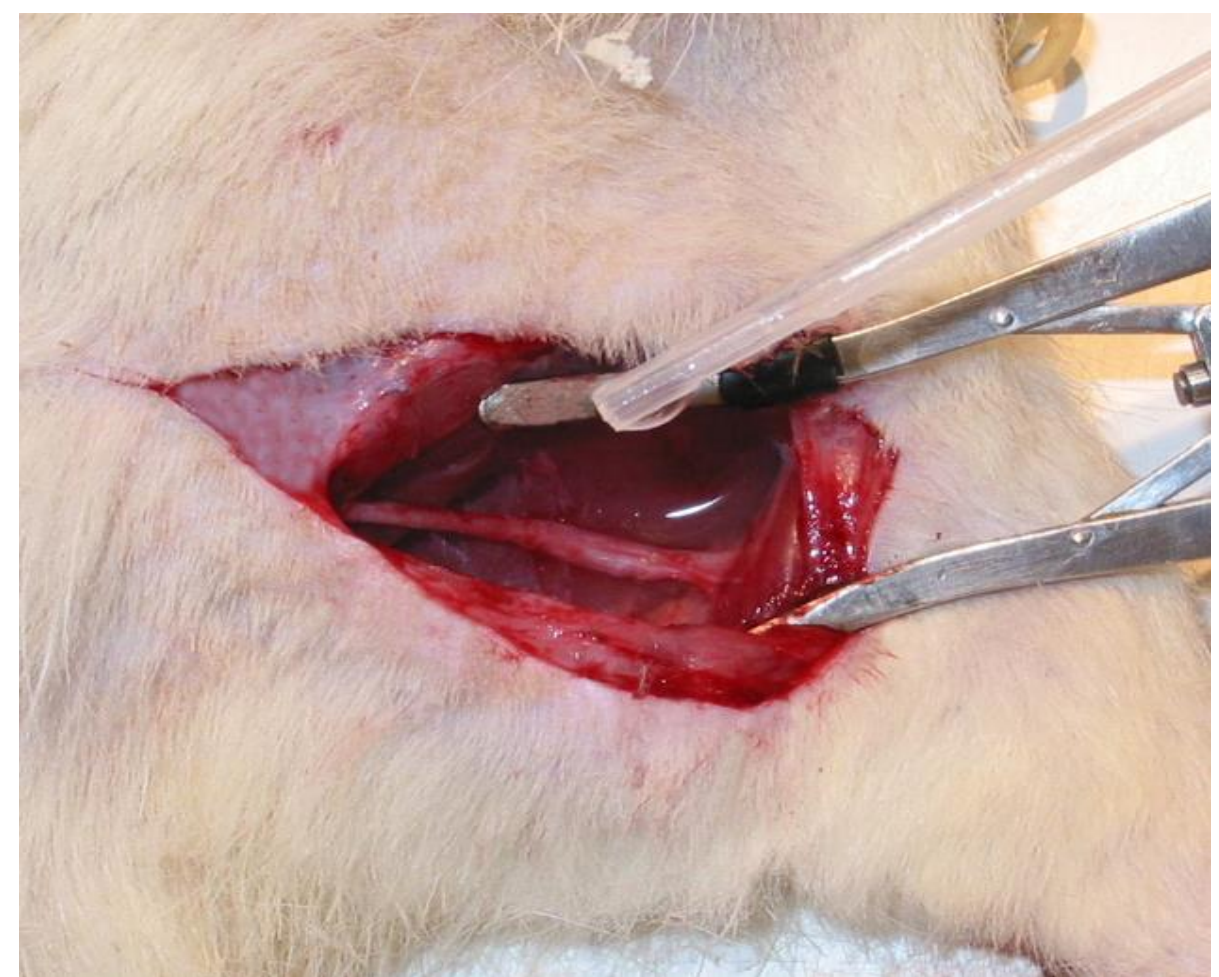

Figura 18 - Foto cirúrgica mostrando a instilação do fixador de Karnovsky sobre o nervo ciático previamente operado.

Nesta etapa a solução era instilada sobre os nervos, embebendo-os por completo. Transcorrido um período de três minutos um segmento de dois $\mathrm{cm}$ do nervo foi retirado, incluindo a região do reparo. A partir de quatro mm proximal e quatro mm distal da região do reparo, através da secção com gilete, foram obtidos dois segmentos de quatro mm de extensão (Figura 19). Esses segmentos foram colocados em frascos identificados contendo solução de Karnovsky e encaminhados 
ao Laboratório de Neurobiologia no Departamento de Biologia Celular e do Desenvolvimento do Instituto de Ciências Biomédicas da Universidade de São Paulo onde foi realizado o processamento do material.
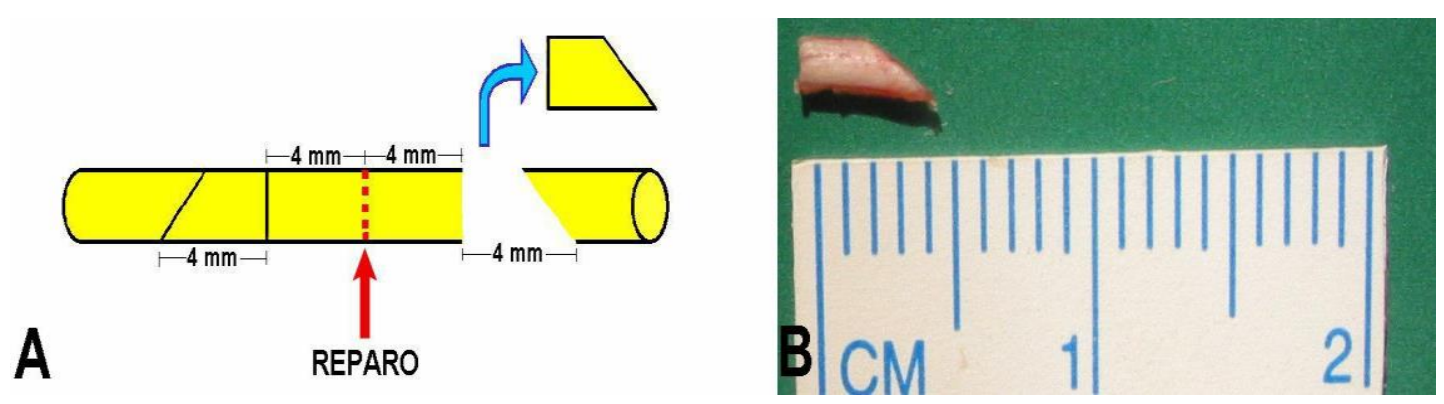

Figura 19 - A - esquema que demonstra as distâncias dos locais de secção dos segmentos proximal e distal em relação à região do reparo e a extensão desses segmentos obtidos após a retirada do nervo ciático operado. B - fotografia do segmento de quatro milímetros de extensão obtido após secção do nervo ciático, realizada quatro milímetros distal ao reparo.

Legenda: cm: centímetros; mm: milímetros.

Cada segmento foi pós-fixado em solução de tetróxido de ósmio a $2 \%$, desidratado em soluções crescentes de álcool etílico, clareado em óxido de propileno, infiltrado e incluído em resina epóxi, o que possibilitou a obtenção de cortes para microscopia de luz. Foram realizados cortes transversais de um $\mu \mathrm{m}$, corados com azul de toluidina a $1 \%$.

O corte do segmento proximal e distal de cada nervo foi analisado para que se obtivesse a contagem total e a avaliação do diâmetro dos axônios mielínicos regenerados. Essa avaliação incluiu ainda a contagem total dos axônios extrafasciculares regenerados no segmento distal.

Para a contagem total dos axônios, cada corte histológico foi fotografado com câmera digital* acoplada ao microscópio no aumento de objetiva de 40 vezes. Os cortes foram analisados no computador com a utilização do programa Sigma Scan Pro $5.0 * *$ obtendo-se uma imagem total do segmento considerado. Com a utilização 
do mesmo programa, em cada segmento foi quantificado o número total de axônios mielínicos regenerados (Figura 20). Esse programa permite que, com o cursor, o axônio regenerado seja marcado definitivamente, impedindo a repetição de sua contagem.

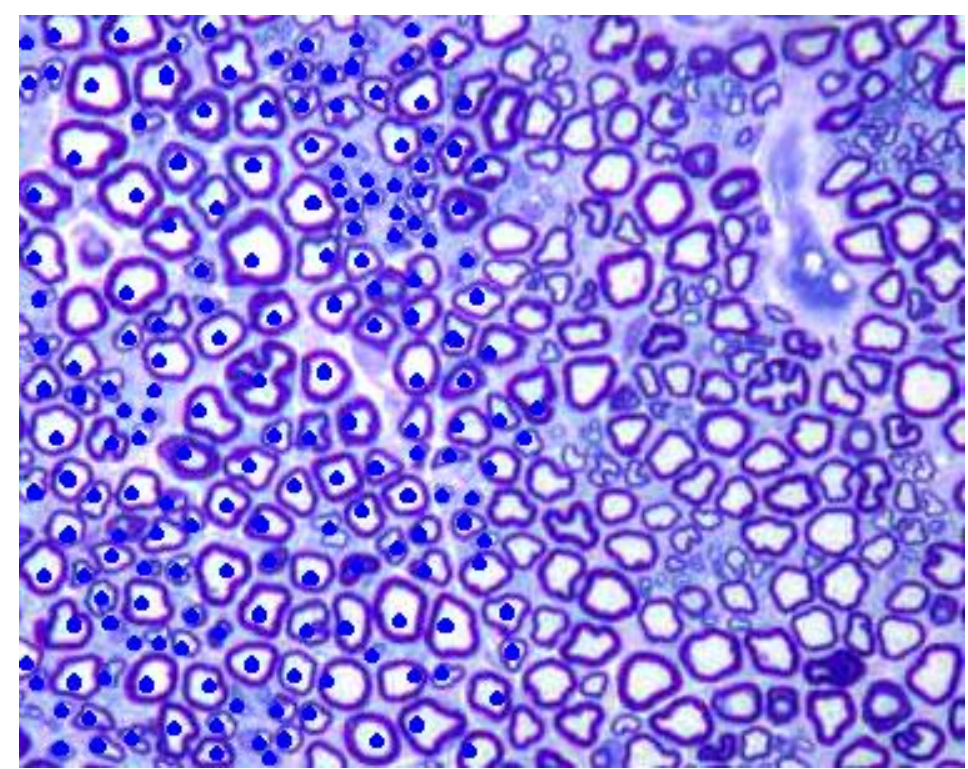

Figura 20 - Fotomicrografia obtida de corte histológico de segmento distal do nervo ciático do rato, que evidencia parte dos axônios que foram contados marcados com círculo azul. Coloração azul de toluidina a $1 \%$.

Com esta avaliação foi possível quantificar a porcentagem de axônios que ultrapassaram a região do reparo através do cálculo do IReg, definido pela divisão do número total de axônios situados na região distal ao reparo pelo número total de axônios localizados na região proximal ao reparo, multiplicado por cem, de acordo com a equação (3) ${ }^{24}$. O cálculo do IReg foi realizado nos três grupos de reparo.

Equação 3: cálculo do índice de regeneração

IReg $=$ (número total de axônios na região distal ao reparo / número total de axônios na região proximal ao reparo) x 100

Legenda: IReg: índice de regeneração. 
Considerando os parâmetros obtidos na quantificação total do número de axônios, a avaliação da regeneração incluiu a comparação da contagem total dos axônios no segmento distal e dos valores do IReg nos três grupos de reparo.

A mensuração do número dos axônios extrafasciculares possibilitou avaliar uma subpopulação dos axônios regenerados que atingiram o segmento distal, mas não se situaram no interior dos fascículos. Para esta finalidade, foram quantificados o número total de axônios extrafasciculares regenerados no segmento distal e a porcentagem desses axônios sobre o número total de axônios regenerados no segmento distal através do cálculo do índice de regeneração dos axônios extrafasciculares (IRE) de acordo com a fórmula (4) ${ }^{247}$.

Equação 4: cálculo do índice de regeneração dos axônios extrafasciculares

IRE $=$ (número total de axônios extrafasciculares no segmento distal / número total de axônios no segmento distal) x 100

Legenda: IRE: índice de regeneração dos axônios extrafasciculares

Considerando os parâmetros obtidos na quantificação do número de axônios extrafasciculares no segmento distal, a avaliação da regeneração incluiu a comparação do número total de axônios extrafasciculares regenerados no segmento distal da região do reparo e do IRE, nos três grupos de reparo.

Para a avaliação do diâmetro dos axônios mielínicos regenerados foram fotografadas cinco amostras de cada corte do segmento do nervo obtidas com a mesma câmera descrita anteriormente, em objetiva de 100 vezes. Essas imagens foram avaliadas pelo mesmo programa de computador descrito para mensuração da contagem dos axônios regenerados. Após a mensuração do perímetro cada axônio era 
marcado definitivamente impedindo a medida do perímetro do axônio já avaliado (Figura 21).

$$
\vdash \text { 10 um-1 }
$$

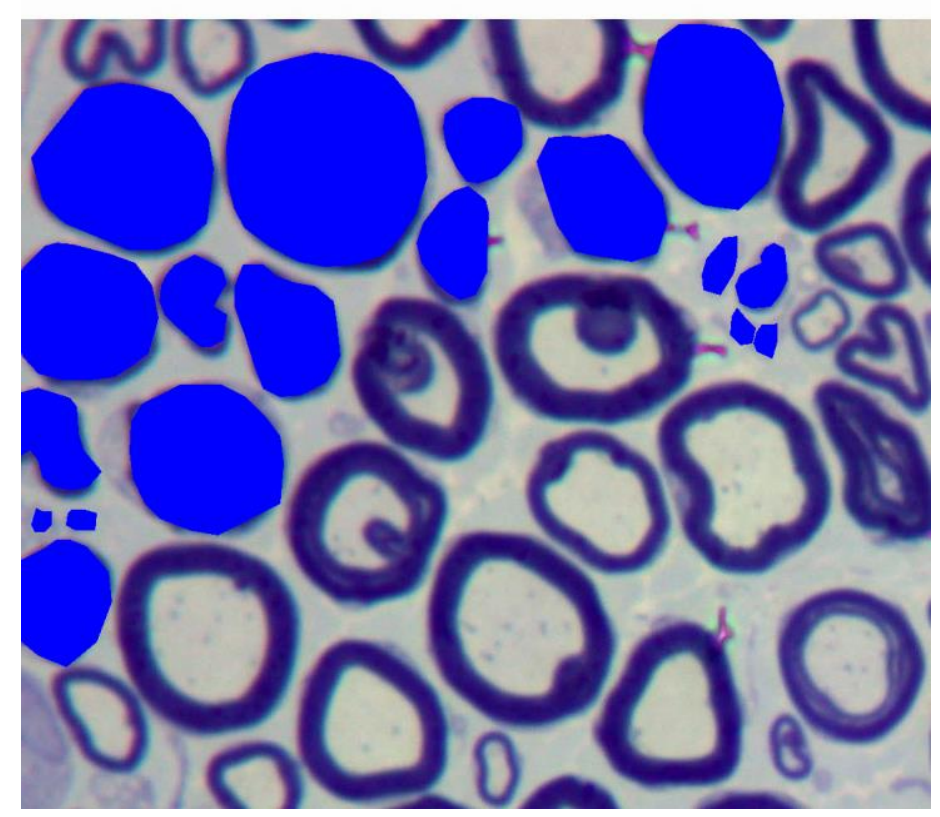

Figura 21 - Fotomicrografia obtida de corte histológico de segmento distal do nervo ciático do rato que evidencia parte dos axônios regenerados com perímetros mensurados preenchidos com cor azul. Coloração azul de toluidina a $1 \%$.

Legenda: $\mu \mathrm{m}$ : micrômetro

O valor do perímetro foi dividido por $\pi(\mathrm{Pi})$ obtendo-se o diâmetro de cada axônio. Com os valores da média dos diâmetros dos axônios nos segmentos proximal (Dmp) e distal (Dmd) de cada nervo foi calculada a porcentagem do Dmd em relação ao Dmp denominado de índice de alteração do diâmetro (IAD) através da equação $(5)^{25}$.

Equação 5: cálculo do índice de alteração do diâmetro

$\mathrm{IAD}=(\mathrm{Dmd} / \mathrm{Dmp}) \times 100$

Legenda: IAD: índice de alteração do diâmetro; Dmd: média dos valores dos diâmetros dos axônios no segmento distal à região do reparo; Dmp: média dos valores dos diâmetros dos axônios no segmento proximal à região do reparo. 
Considerando os parâmetros obtidos na mensuração dos diâmetros, a avaliação da regeneração incluiu a comparação dos valores de Dmd e do IAD nos três grupos de reparo. Ao término das mensurações os valores de todos os parâmetros obtidos foram reduzidos a dois dígitos decimais.

Após a obtenção do material para análise, os animais foram sacrificados através da administração intraperitoneal de pentobarbital sódico em altas doses.

\subsection{Estatística}

Para a análise estatística os valores obtidos dos vários parâmetros foram submetidos ao teste de homogeneidade de variâncias entre os grupos e, quando necessário, à transformação logarítmica*. Quando esses valores eram homogêneos, a comparação entre os grupos de tratamento foi estabelecida através da análise de variância considerando um fator. Quando foi identificada uma diferença significativa entre os grupos, para $p<0,05$, foi utilizado um teste de comparações múltiplas através do método de Tukey ou Duncan. Quando os parâmetros não eram homogêneos, a comparação entre os grupos de tratamento foi realizada através do teste de KruskalWallis. Toda a avaliação estatística foi realizada com o auxílio do programa Statgraphics plus versão 5.0**.

*A análise foi realizada pela estatística Regina Duarte Prisco, Departamento de Anatomia do Instituto de Ciências Biomédicas da Universidade de São Paulo.

**Manugistics Incorporation, Rockville, E.U.A. 
5. RESULTADOS 


\section{Resultados}

\subsection{Avaliação Funcional da Marcha}

O IFC1 variou de $-9,96$ a 4,64 com média de $-2,48 \pm 4,36$ nos três grupos. $\mathrm{O}$ IFC1 variou de $-9,96$ a 2,28 no grupo $A$, de $-9,91$ a 2,15 no grupo $B$ e de $-8,85$ a 4,64 no grupo C. A média do IFC1 nos grupos A, B e C foi $-3,83 \pm 4,59,-3,61 \pm 4,61$ e $-4,50 \pm 4,30$, respectivamente. Não houve diferença estatisticamente significativa entre os valores do IFC1 nos três grupos $(\mathrm{p}=0.905)$.

O IFC2 variou de $-18,34$ a $-69,2$ com média de $-45,00 \pm 11,46$ nos 30 animais. O IFC2 variou de $-64,60$ a $-42,02$ no grupo A, de $-53,21$ a -18,35 no grupo B e de 69,20 a $-25,88$ no grupo $C$. Nos grupos A, B e C a média do IFC2 foi respectivamente $-51,86 \pm 7,74,-38,65 \pm 9,88$ e $-44,48 \pm 12,97$. Na avaliação do IFC2, foi identificada uma diferença estatisticamente significativa entre o grupo A e o grupo B pelo método de Tukey para $\mathrm{p}<0,05$.

O gráfico 1 ilustra a distribuição dos valores do IFC de acordo com o reparo adotado antes da primeira cirurgia e após doze semanas de observação. 


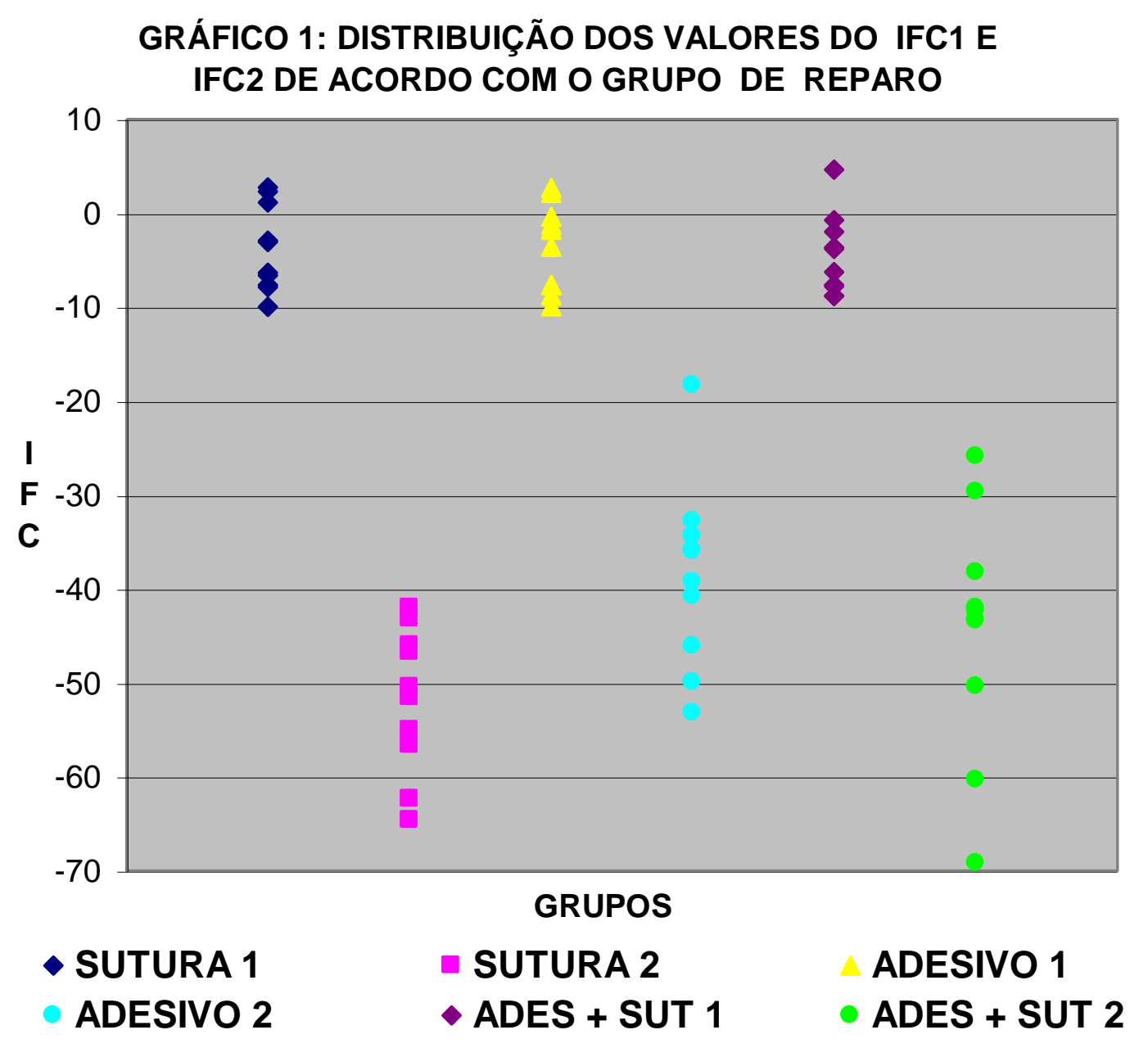

Legenda: Adesivo 1: valores do IFC1 no grupo B (adesivo); Adesivo 2: valores do IFC2 no grupo B (adesivo); Ades + sut 1: valores do IFC1 no grupo C (adesivo e sutura); Ades + sut 2: valores do IFC2 no grupo C (adesivo e sutura); IFC: índice funcional ciático; Sutura 1: valores do IFC1 no grupo A (sutura); Sutura 2: valores do IFC2 no grupo A (sutura).

A análise do gráfico 1 permite observar que, com relação aos valores do IFC1, a distribuição aparenta ser semelhante nos três grupos, o que foi confirmado pela análise estatística. $\mathrm{Na}$ avaliação do IFC2, os valores do grupo A condensam-se em valores inferiores em relação aos valores dos grupos B, constatação confirmada pela análise estatística.

Os resultados da mensuração dos parâmetros obtidos para o cálculo do IFC1 e IFC2 para cada animal estão relacionados no anexo $\mathrm{C}$ e $\mathrm{D}$, respectivamente. 


\subsection{Avaliação Eletrofisiológica}

\subsubsection{Avaliação do Potencial de Ação do Nervo}

Na avaliação do PAN1, a LATN1 variou de a 0,15 a 0,58 com média de $0,27 \pm$ 0,12 ms nos três grupos. A LATN1 variou de 0,15 a 0,50 com média de $0,26 \pm 0,10$ ms no grupo $\mathrm{A}$, de 0,15 a 0,58 com média de $0,30 \pm 0,16$ ms no grupo $\mathrm{B}$ e de 0,15 a 0,38 com média de 0,24 $\pm 0,08$ ms no grupo C. Não houve diferença estatisticamente significativa dos valores da LATN1 entre os três grupos $(\mathrm{p}=0,508)$.

A LATN2 variou de a 0,17 a 0,75 com média de $0,36 \pm 0,16 \mathrm{~ms}$ nos três grupos. A LATN2 variou de 0,21 a 0,75 com média de $0,41 \pm 0,20 \mathrm{~ms}$ no grupo A, de 0,17 a 0,67 com média de $0,34 \pm 0,15 \mathrm{~ms}$ no grupo $\mathrm{B}$ e de 0,21 a 0,54 com média de $0,33 \pm 0,10 \mathrm{~ms}$ no grupo C. A análise estatística evidenciou uma diferença significativa entre os valores da LATN2 obtidos nos grupo A e B pelo método de Tukey para $\mathrm{p}<0,05$

A VCN1 variou de 34,48 a $133,33 \mathrm{~m} / \mathrm{s}$ nos três grupos com média de $86,96 \pm$ $29,97 \mathrm{~m} / \mathrm{s}$. Este parâmetro variou de 40,00 a 133,33 com média de 86,07 $\pm 27,02 \mathrm{~m} / \mathrm{s}$ no grupo A, de 34,48 a 133,33 com média de $82,64 \pm 35,94 \mathrm{~m} / \mathrm{s}$ no grupo $\mathrm{B}$ e de 52,63 a 133,33 com média de $92,18 \pm 28,63 \mathrm{~m} / \mathrm{s}$ no grupo $\mathrm{C}$. Não houve diferença estatisticamente significativa dos valores da VCN1 entre os três grupos $(\mathrm{p}=0,783)$.

A VCN2 variou de 26,67 a 117,65 m/s nos três grupos com média de 64,96 \pm 24,54 m/s. Esse parâmetro variou de 26,67 a 90,91 com média de 59,55 —26,19 m/s no grupo A, de 29,85 a 117,65 com média de 69,09 $\pm 28,85$ no grupo B e de 37,04 a 95,24 com média de $66,24 \pm 19,21 \mathrm{~m} / \mathrm{s}$ no grupo C. Não houve diferença estatisticamente significativa dos valores da VCN2 entre os três grupos $(p=0,687)$. 
O gráfico 2 demonstra a distribuição dos valores da VCN1 e VCN2 de acordo com o grupo de reparo.

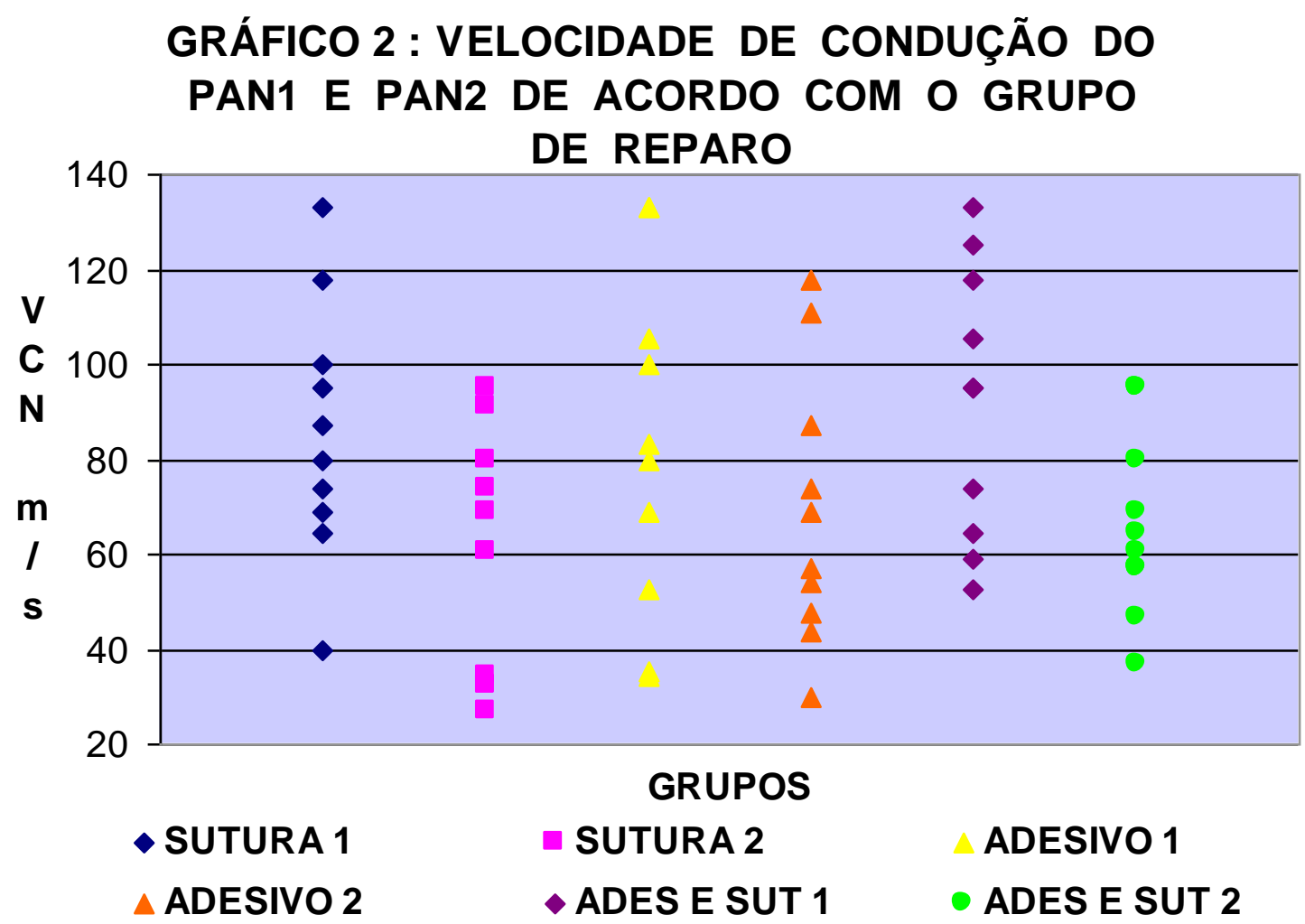

Legenda: Adesivo 1: valores da VCN1 no grupo B (adesivo); Adesivo 2: valores da VCN2 no grupo B (adesivo); Ades + sut 1: valores da VCN1 no grupo C (adesivo e sutura); Ades + sut 2: valores da VCN2 no grupo C (adesivo e sutura); m/s: metros por segundo; Sutura 1: valores da VCN no grupo A (sutura); Sutura 2: valores da VCN2 no grupo A (sutura); VCN: velocidade de condução do PAN

$\mathrm{Na}$ análise do gráfico 2 nota-se que os valores da VCN1 foram semelhantes antes e após a cirurgia nos três grupos com exceção de dois animais do grupo B cujos resultados da VCN2 foram superiores aos melhores resultados dos outros dois grupos. Estes dados não influenciaram o resultado da avaliação estatística.

Houve melhora da VC do PAN em sete animais decorrido o período de observação após o procedimento cirúrgico. Um desses animais era do grupo A, quatro desses animais pertenciam ao grupo $\mathrm{B}$ e dois ao grupo $\mathrm{C}$. Conseqüentemente a $\% \mathrm{VCN}$ foi superior a $100 \%$ nesses animais. A \% VCN variou de 37,31 a $156,76 \mathrm{com}$ 
média de 79,75 \pm 31,55 \% nos três grupos. Esse parâmetro variou de 41,33 a 119,05 com média de 69,19 \pm 23,84 \% no grupo A, de 37,31 a 156,76 com média de 92,74 \pm $37,53 \%$ no grupo B e de 45,45 a 128,57 com média de 77,31 $\pm 30,22 \%$ no grupo C. Não houve diferença estatisticamente significativa dos valores da \% VCN entre os três grupos $(\mathrm{p}=0,244)$.

A AMPN1 variou de 0,42 a 2,35 mV nos três grupos com média de 1,19 $\pm 0,59$ $\mathrm{mV}$. Esse parâmetro variou de $0,45 \mathrm{a} 2,30 \mathrm{mV}$ com média de $1,29 \pm 0,66$ no grupo A, de 0,42 a 2,35 com média de $1,15 \pm 0,59$ no grupo B e de 0,46 a 2,10 com média de $1,14 \pm 0,56 \mathrm{mV}$ no grupo $\mathrm{C}$. Não houve diferença estatisticamente significativa dos valores da AMPN1 entre os três grupos $(\mathrm{p}=0,833)$.

A AMPN2 variou de 0,11 a $1,80 \mathrm{mV}$ nos três grupos com média de $0,51 \pm 0,40$ $\mathrm{mV}$. Esse parâmetro variou de 0,11 a $0,85 \mathrm{mV}$ com média de $0,37 \pm 0,26$ no grupo A, de 0,11 a 1,80 com média de $0,70 \pm 0,52$ no grupo B e de 0,04 a 1,11 com média de $0,45 \pm 0,33 \mathrm{mV}$ no grupo $\mathrm{C}$. Não houve diferença estatisticamente significativa dos valores da AMPN2 entre os três grupos $(\mathrm{p}=0,167)$.

O gráfico 3 ilustra a distribuição dos valores das amplitudes do PAN1 e PAN2 de acordo com o reparo utilizado. 


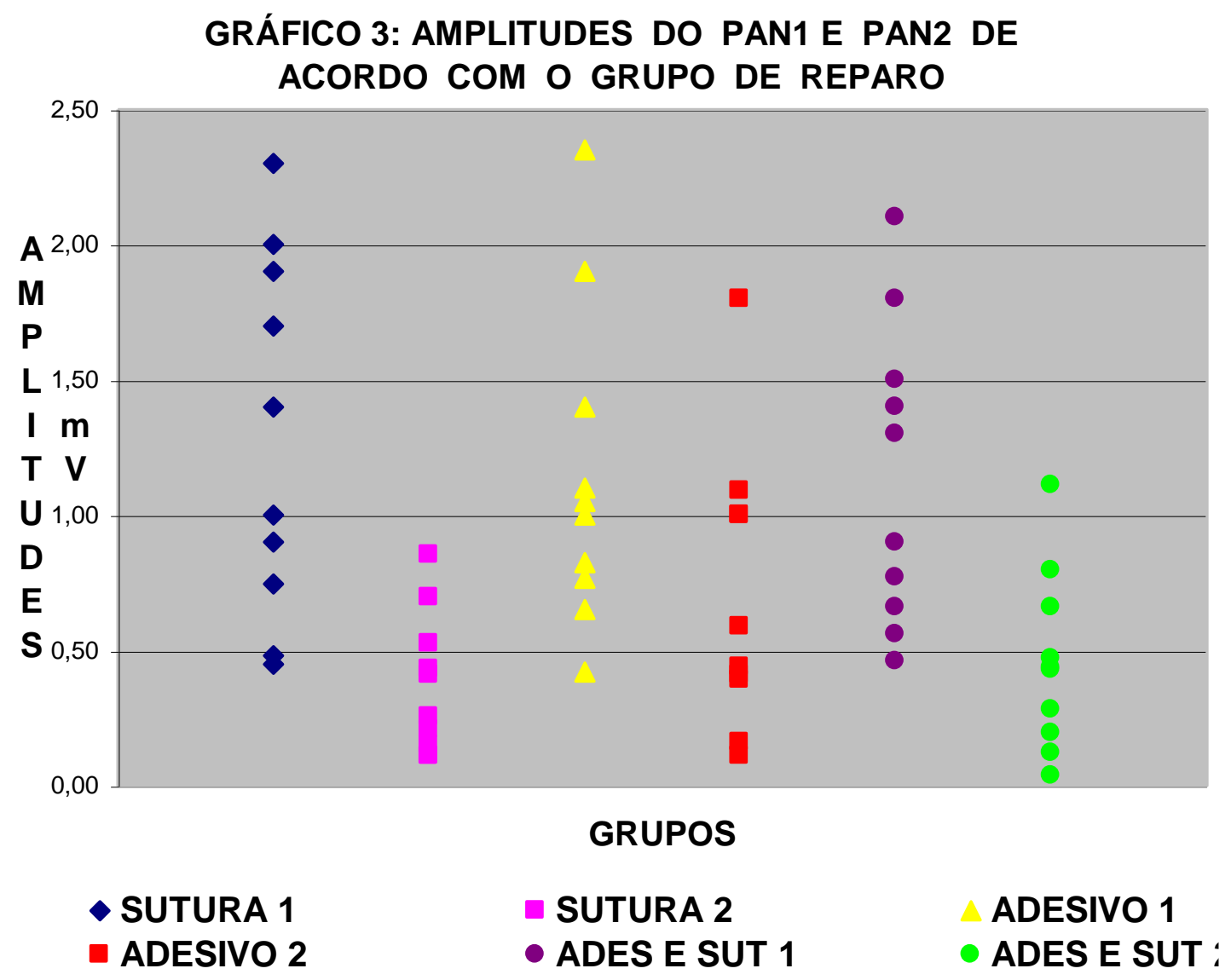

Legenda: Adesivo 1: valores da AMPN1 no grupo B (adesivo); Adesivo 2: valores da AMPN2 no grupo B (adesivo); Ades + sut 1: valores da AMPN1 no grupo C (adesivo e sutura); Ades + sut 2: valores da AMPN2 no grupo C (adesivo e sutura); mV: milivolt; Sutura 1: valores da AMPN1 no grupo A (sutura); Sutura 2: valores da AMPN2 no grupo A (sutura).

Observa-se no gráfico 3 que o comportamento das alterações relacionadas à modificação da amplitude foram semelhantes nos três grupos, com exceção de três animais do grupo B que apresentaram valores de AMPN2 superiores aos valores do grupo A. Esses achados não influenciaram o resultado da comparação estatística.

Houve melhora da amplitude do PAN em cinco animais decorrido o período de observação após o procedimento cirúrgico. Quatro desses animais pertenciam ao grupo B e um ao grupo C. Consequientemente a \%AMPN foi superior a $100 \%$ nesses animais. A \%AMPN variou de 2,03 a $180 \%$ nos três grupos com média de 55,88 \pm $52,11 \%$. Esse parâmetro variou de 5,50 a 37,50 com média de 32,93 $\pm 21,60 \%$ no 
grupo A, de 5,79 a 180 com média de $82,85 \pm 66,51 \%$ no grupo B e de 2,03 a 173,04 com média de 51,87 \pm 49,50 \% no grupo C. Não houve diferença estatisticamente significativa dos valores da \%AMPN entre os três grupos $(\mathrm{p}=0,401)$.

Os valores dos parâmetros obtidos com a avaliação do PAN para cada animal estão relacionados no anexo E.

\subsubsection{Avaliação do Potencial de Ação Motor}

Na avaliação do PAM, a LATM1 variou de 1,21 a 2,20 com média de 1,55 \pm 0,26 ms nos três grupos. A LATM1 variou de 1,25 a 1,75 com média de 1,48 $\pm 0,17$ ms no grupo A, de 1,29 a 1,75 com média de 1,51 \pm 0,16 ms no grupo B e de 1,21 a 2,20 com média de 1,67 $\pm 0,38$ ms no grupo C. Não houve diferença estatisticamente significativa dos valores da LATM1 entre os três grupos $(\mathrm{p}=0,602)$.

A LATM2 variou de 1,46 a 2,90 com média de 1,90 \pm 0,36 ms nos três grupos. Esse parâmetro variou de 1,70 a 2,90 com média de 2,13 $\pm 0,48$ ms no grupo A, de 1,58 a 2,00 com média de $1,74 \pm 0,19$ ms no grupo $\mathrm{B}$ e de 1,60 a 2,20 com média de $1,85 \pm 0,25 \mathrm{~ms}$ no grupo C. A análise estatística evidenciou uma diferença significativa entre o grupo A e o grupo B pelo método de Tukey para $p<0,05$ na avaliação desse parâmetro.

A VCM1 variou de 13,64 a 24,79 m/s nos três grupos com média de 19,79 \pm $3,06 \mathrm{~m} / \mathrm{s}$. Esse parâmetro variou de 17,14 a $24,00 \mathrm{~m} / \mathrm{s}$ com média de 20,47 $\pm 2,34$ no grupo A, de 17,14 a 23,26 m/s com média de 20,04 $\pm 2,20$ no grupo B e de 13,64 a 
$24,79 \mathrm{~m} / \mathrm{s}$ com média de $18,85 \pm 4,27 \mathrm{~m} / \mathrm{s}$ no grupo $\mathrm{C}$. Não houve diferença estatisticamente significativa dos valores da VCM1 entre os três grupos $(\mathrm{p}=0.602)$.

A VCM2 variou de 10,34 a 20,55 m/s nos três grupos com média de 16,22 \pm $2,55 \mathrm{~m} / \mathrm{s}$. Esse parâmetro variou de 10,34 a 17,65 m/s com média de 14,71 $\pm 2,91$ $\mathrm{m} / \mathrm{s}$ no grupo $\mathrm{A}$, de 15,00 a $20,55 \mathrm{com}$ média de $17,44 \pm 1,85 \mathrm{~m} / \mathrm{s}$ no grupo $\mathrm{B}$ e de 13,64 a 19,48 com média de 16,51 $\pm 2,19 \mathrm{~m} / \mathrm{s}$ no grupo C. Na avaliação estatística da VCM2, foi identificada uma diferença significativa entre o grupo A e o grupo B pelo método de Tukey para $\mathrm{p}<0,05$.

O gráfico 4 ilustra os valores das VCM1 e VCM2 de acordo com o grupo de reparo.

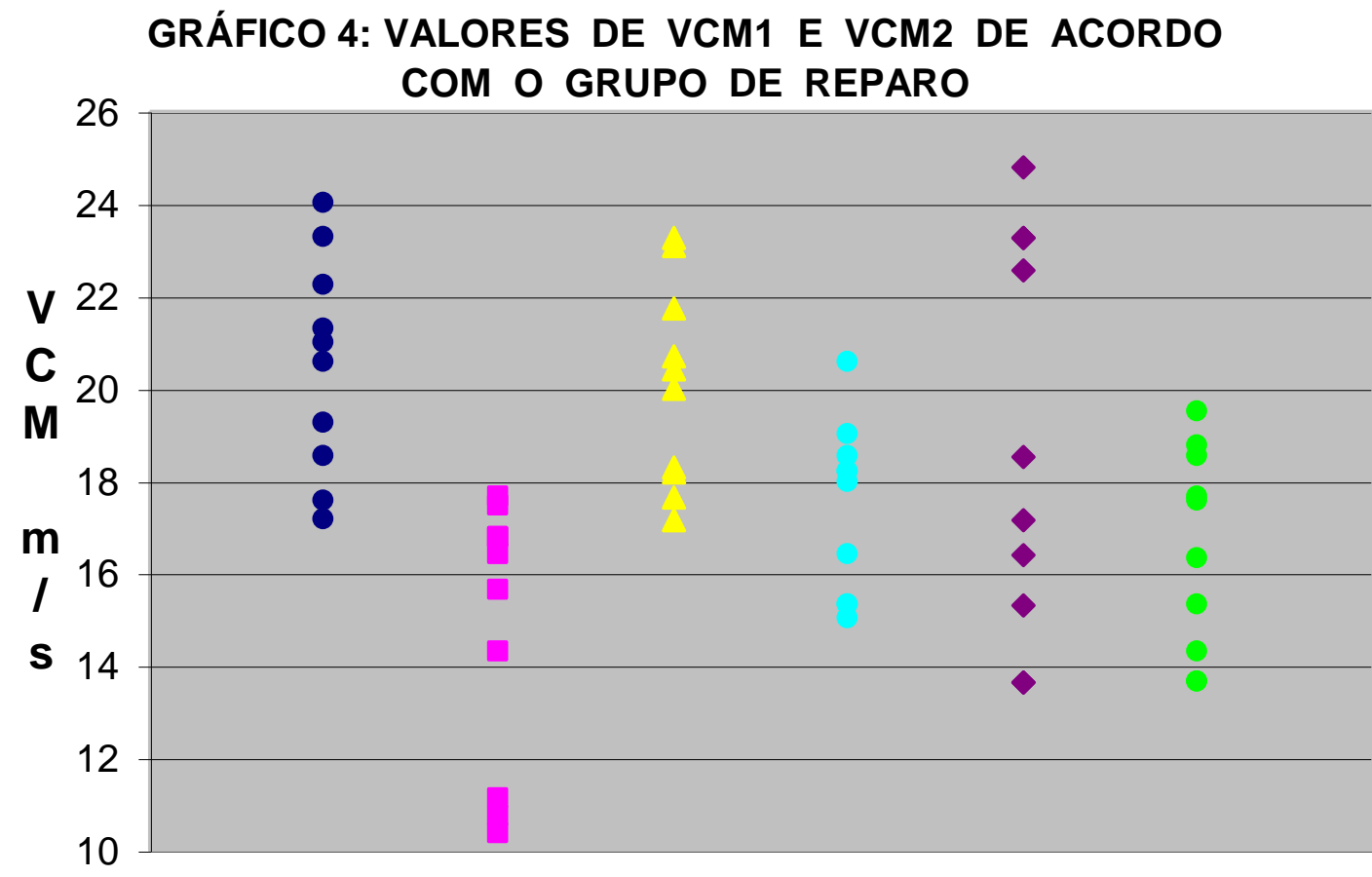

- SUTURA 1

- ADESIVO 2

\section{GRUPOS}

- SUTURA 2

- ADES E SUT 1
ADESIVO 1

ADES E SUT 2

Legenda: Adesivo 1: valores da VCM1 no grupo B (adesivo); Adesivo 2: valores da VCM2 no grupo B (adesivo); Ades + sut 1: valores da VCM1 no grupo C (adesivo e sutura); Ades + sut 2: valores da VCM2 no grupo C (adesivo e sutura); m/s: metros por segundo; Sutura 1: valores da VCM1 no grupo A (sutura); Sutura 2: valores da VCM2 no grupo A (sutura). 
$\mathrm{Na}$ análise do gráfico 4, os valores obtidos da VCM1 no grupo C estão mais dispersos em relação aos dois outros grupos de reparo, distribuição que não influenciou a análise estatística. Evidencia-se também que os valores da VCM2 do grupo B são superiores, na sua maioria, em relação aos do grupo A e têm comportamento semelhante aos do grupo C. Essa observação apresentou congruência com a avaliação estatística.

Houve melhora da VC do PAM em seis animais decorrido o período de observação após o procedimento cirúrgico. Dois desses animais pertenciam ao grupo B e quatro ao grupo C. Conseqüentemente a \%VCM foi superior a $100 \%$ nesses animais. A \%VCM variou de 44,64 a 119,86 com média de 83,76 $\pm 17,73 \%$ nos três grupos. Esse parâmetro variou de 44,64 a 95,53 com média de 72,73 $\pm 16,71 \%$ no grupo A, de 65,82 a 119,86 com média de 88,22 $\pm 15,62 \%$ no grupo B e de 71,18 a 112,96 com média de $90,33 \pm 16,85 \%$ no grupo C. Na avaliação da \%VCM, foi identificada uma diferença estatisticamente significativa entre o grupo A e o grupo B e entre o grupo A e o grupo C pelo método de Duncan para $\mathrm{p}<0,05$.

A AMPM1 variou de 0,72 a 9,60 com média de 4,97 $\pm 2,20 \mathrm{mV}$ nos três grupos. Esse parâmetro variou de 0,72 a 9,60 com média de 5,12 $\pm 3,23 \mathrm{mV}$ no grupo A, de 2,30 a 7,30 com média de 5,15 $\pm 1,77 \mathrm{mV}$ no grupo B e de 3,10 a 6,30 com média de 4,65 $\pm 1,33 \mathrm{mV}$ no grupo C. Não houve diferença estatisticamente significativa da AMPM1 entre os três grupos $(\mathrm{p}=0,719)$.

A AMPM2 variou de 0,48 a 8,20 com média de 4,41 $\pm 2,05 \mathrm{mV}$ nos três grupos. Esse parâmetro variou de 0,48 a 7,70 com média de 4,20 $\pm 2,48 \mathrm{mV}$ no grupo A, de 1,30 a 8,20 com média de 4,95 $\pm 2,01 \mathrm{mV}$ no grupo B e de 2,70 a 7,10 
com média de 4,08 $\pm 1,69 \mathrm{mV}$ no grupo C. Não houve diferença estatisticamente significativa da AMPM2 entre os três grupos $(\mathrm{p}=0,603)$.

Houve melhora da AMPM2 em 12 animais decorrido o período de observação após o procedimento cirúrgico. Três desses animais pertenciam ao grupo A, cinco ao grupo B e quatro ao grupo C. Conseqüentemente a \%AMPM foi superior a $100 \%$ nesses animais. A \%AMPM variou de 26,44 a 353,09 com média de 107,90 \pm 76,15 \% nos três grupos. Esse parâmetro variou de 26,44 a 353,09 com média de 117,83 \pm $103,40 \%$ no grupo A, de 31,71 a 291,30 com média de $110,76 \pm 73,75 \%$ no grupo B e de 39,13 a 161,90 com média de 95,11 $\pm 47,49 \%$ no grupo C. Não houve diferença estatisticamente significativa dos valores da \%AMPM entre os três grupos $(\mathrm{p}=0,803)$.

O gráfico demonstra a distribuição dos valores das amplitudes do PAM1 e PAM2 de acordo com o grupo de reparo. A análise do gráfico mostra que os valores de AMPM1 no grupo $\mathrm{C}$ apresentam-se mais concentrados na faixa de valor de dois a oito $\mathrm{mV}$ em comparação com os outros grupos de reparo, mas sem significado na avaliação estatística. Os valores da AMPM2 apresentam distribuição semelhante entre os três grupos.

O gráfico 5 ilustra os valores das amplitudes do PAM1 e PAM2 de acordo com o grupo de reparo. 


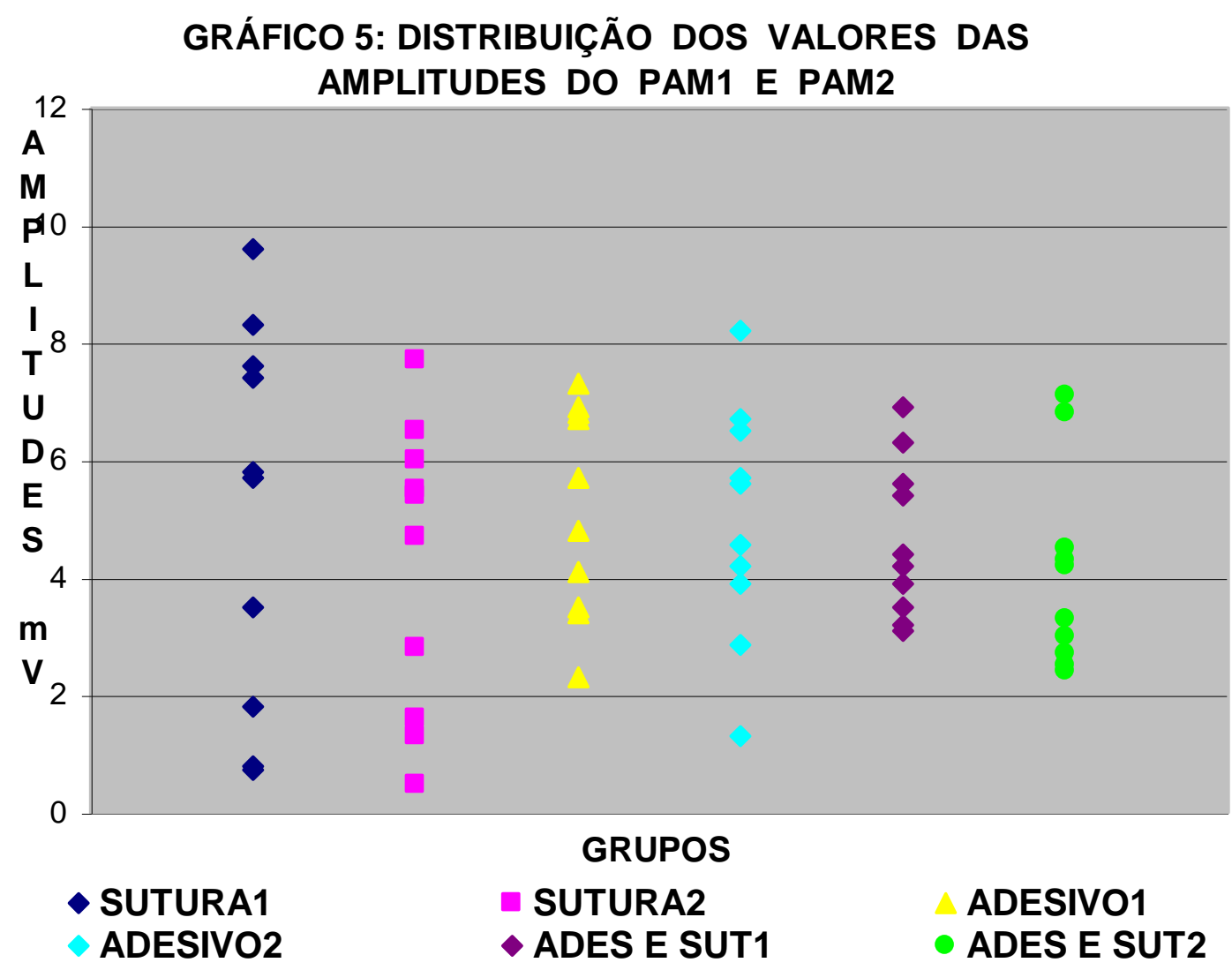

Legenda: Adesivo 1: valores da AMPM1 no grupo B (adesivo); Adesivo 2: valores da AMPM2 no grupo B (adesivo); Ades + sut 1: valores da AMPM1 no grupo C (adesivo e sutura); Ades + sut 2: valores da AMPM2 no grupo C (adesivo e sutura); mV: milivolt; Sutura 1: valores da AMPM1 no grupo A (sutura); Sutura 2: valores da AMPM2 no grupo A (sutura).

No gráfico 5 nota-se que os valores de AMPM1 no grupo A estão distribuídos de forma mais dispersa em relação aos dos grupos B e C. Essa distribuição não apresentou influência sobre a avaliação estatística. Os valores obtidos com a avaliação do PAM2 apresentaram distribuição semelhante nos três grupos de reparo.

Os resultados dos parâmetros obtidos com a avaliação do PAM para cada animal estão relacionados no anexo $\mathrm{F}$. 


\subsection{Avaliação Histomorfométrica}

Para a avaliação do número total de axônios regenerados foram contados 359440 axônios no segmento proximal ao reparo e 321713 axônios no segmento distal ao reparo nos três grupos. O número de axônios situados na região proximal à região do reparo variou de 8039 a 16603, com média de $11981,33 \pm 1982,40$ nos três grupos. Nos grupos $\mathrm{A}, \mathrm{B}$ e $\mathrm{C}$ a média do número de axônios na região proximal à região do reparo foi, respectivamente, $11055,1 \pm 1129,71,12053 \pm 2434,04 \mathrm{e}$ $12836,4 \pm 1921,20$. Não houve diferença estatisticamente significativa dos valores da contagem total de axônios no segmento proximal entre os três grupos $(\mathrm{p}=0,149)$.

O número de axônios localizados na região distal ao ponto de reparo variou de 3542 a 12935, com média de 10723,77 $\pm 1793,77$ nos três grupos. Nos grupos A, B e C a média do número de axônios na região distal ao reparo foi, respectivamente, $10000,7 \pm 2599,78,11201,5 \pm 1269,98$ e 10969,10 $\pm 1046,30$. Não houve diferença estatisticamente significativa entre os valores da contagem total de axônios no segmento distal entre os três grupos $(\mathrm{p}=0,568)$.

O gráfico 6 situa os valores da contagem total de axônios regenerados no segmento distal em relação ao segmento proximal de cada animal de acordo com o grupo de reparo. 


\section{GRÁFICO 6: SITUAÇÃO DE CADA ANIMAL EM RELAÇÃO À CONTAGEM TOTAL DE AXÔNIOS NO SEGMENTO DISTAL E PROXIMAL NOS TRÊS GRUPOS DE REPARO}

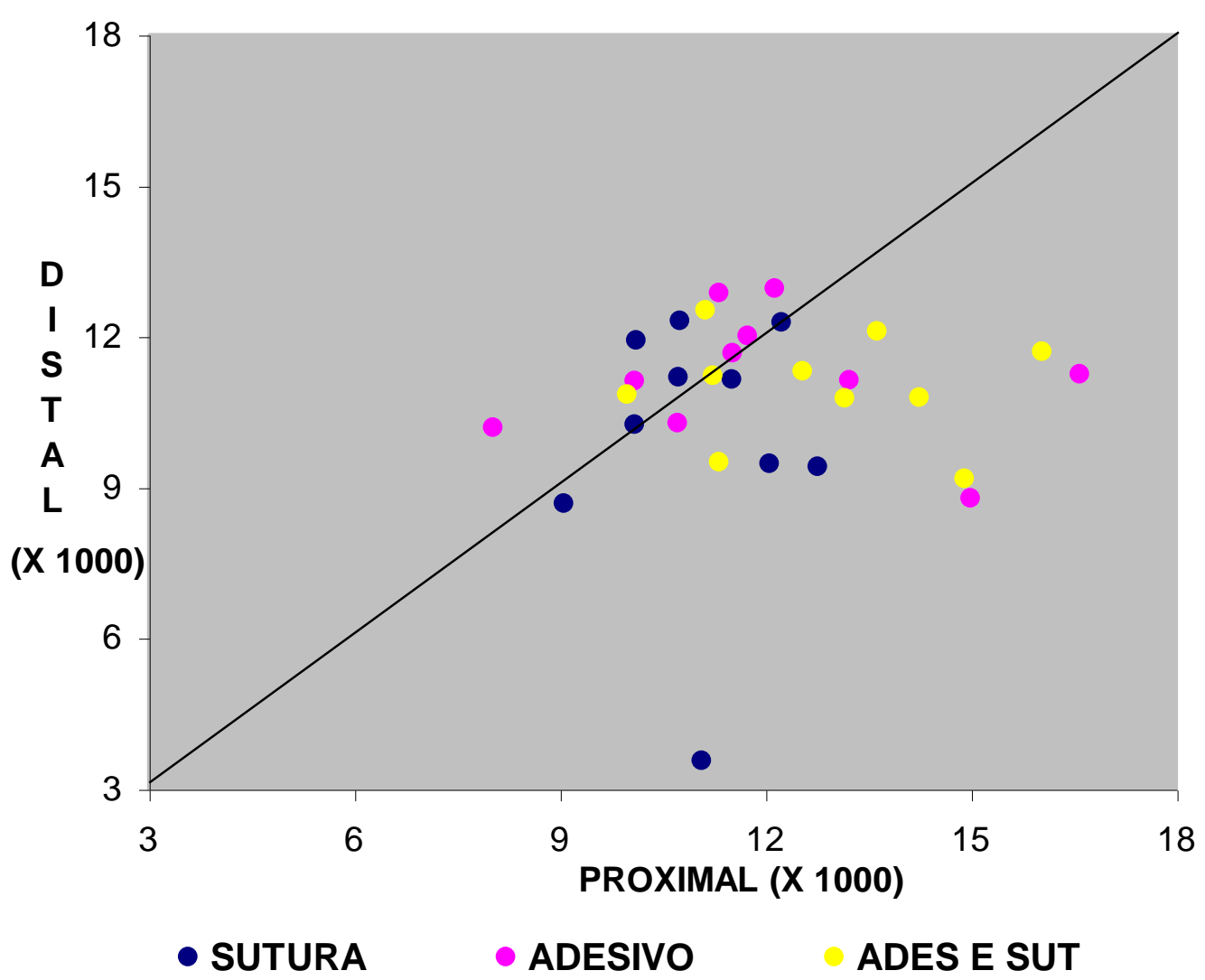

Legenda: Adesivo: grupo de animais submetidos ao reparo com adesivo; Ades e sut: grupo de animais submetidos ao reparo com adesivo e sutura; Sutura: grupo de animais submetidos ao reparo com sutura.

A linha reta divide a área do gráfico 6 em duas regiões. Na inferior estão situados os animais cuja contagem de axônios no segmento proximal ao reparo foi superior à contagem no segmento distal. O contrário ocorre na região superior do gráfico. Nota-se que, com exceção de um animal do grupo A e de dois animais dos grupos B e C, a disposição destes foi semelhante, o que se confirmou com a avaliação estatística. 
O IReg variou de $32 \%$ a $126 \%$ nos três grupos com média de 91,64 $\pm 20,54$ \%. Nos grupos A, B e C a média do IReg foi $91,23 \pm 24,93 \%, 96,4 \pm 20,94 \%$ e 87,3 $\pm 15,91 \%$, respectivamente. Em $60 \%$ dos animais do grupo B, em $50 \%$ dos animais do grupo A e em $20 \%$ dos animais do grupo C, o IReg foi superior a $100 \%$. Não houve diferença estatisticamente significativa dos valores do IReg entre os três grupos $(\mathrm{p}=0,625)$.

O número de axônios regenerados em situação extrafascicular situados na região distal ao reparo variou de 0 a 2821 com média de $772,83 \pm 782,23$ nos três grupos. Nos grupos A, B e C a média do número dos mesmos foi 934,30 $\pm 795,48$, $817,80 \pm 678,13$ e $566,40 \pm 894,65$, respectivamente. Não houve diferença estatisticamente significativa dos valores do número de axônios extrafasciculares no segmento distal entre os três grupos $(\mathrm{p}=0,578)$.

O IRE variou de 0 a 22,58 \% com média de 7,41 $\pm 7,04 \%$ nos três grupos.O valor do IRE variou de 0,03 a 18,82 \% com média de 9,32 \pm 6,74 \% no grupo A, de 0,03 a $17,22 \%$ com média de 7,82 $\pm 6,86 \%$ no grupo B e de 0 a 22,58 \% com média de 5,09 \pm 7,55 \% no grupo C. Não houve diferença estatisticamente significativa dos valores do IRE entre os três grupos de reparo $(\mathrm{p}=0,409)$.

Para a avaliação do diâmetro dos axônios foram mensurados 27187 axônios no segmento proximal ao reparo e 31491 axônios no segmento distal em todos os animais. O diâmetro dos axônios no segmento proximal ao reparo variou de 7,38 a $22,28 \mu \mathrm{ms}$ com média de $10,83 \pm 3,54 \mu \mathrm{ms}$ nos três grupos. A média dos diâmetros dos axônios no segmento proximal nos grupos A, B e C foi, respectivamente, 9,48 \pm $1,78,12,13 \pm 4,72$ e $10,89 \pm 3,30 \mu \mathrm{ms}$. Não houve diferença estatisticamente 
significativa dos valores dos diâmetros dos axônios no segmento proximal entre os três grupos $(\mathrm{p}=0,294)$.

O diâmetro dos axônios na região distal ao reparo variou de 6,8 a $18,99 \mu \mathrm{ms}$ com média de 9,55 $\pm 3,36 \mu \mathrm{ms}$. A média dos diâmetros dos axônios na região distal nos grupos $\mathrm{A}, \mathrm{B}$ e $\mathrm{C}$ foi $8,28 \pm 1,85,11,05 \pm 4,49$ e $9,33 \pm 2,90 \mu \mathrm{ms}$, respectivamente. Não houve diferença estatisticamente significativa dos valores dos diâmetros dos axônios no segmento distal entre os três grupos $(\mathrm{p}=0,227)$. O gráfico 7 demonstra a situação de cada animal em relação ao diâmetro distal e proximal em cada grupo de reparo.

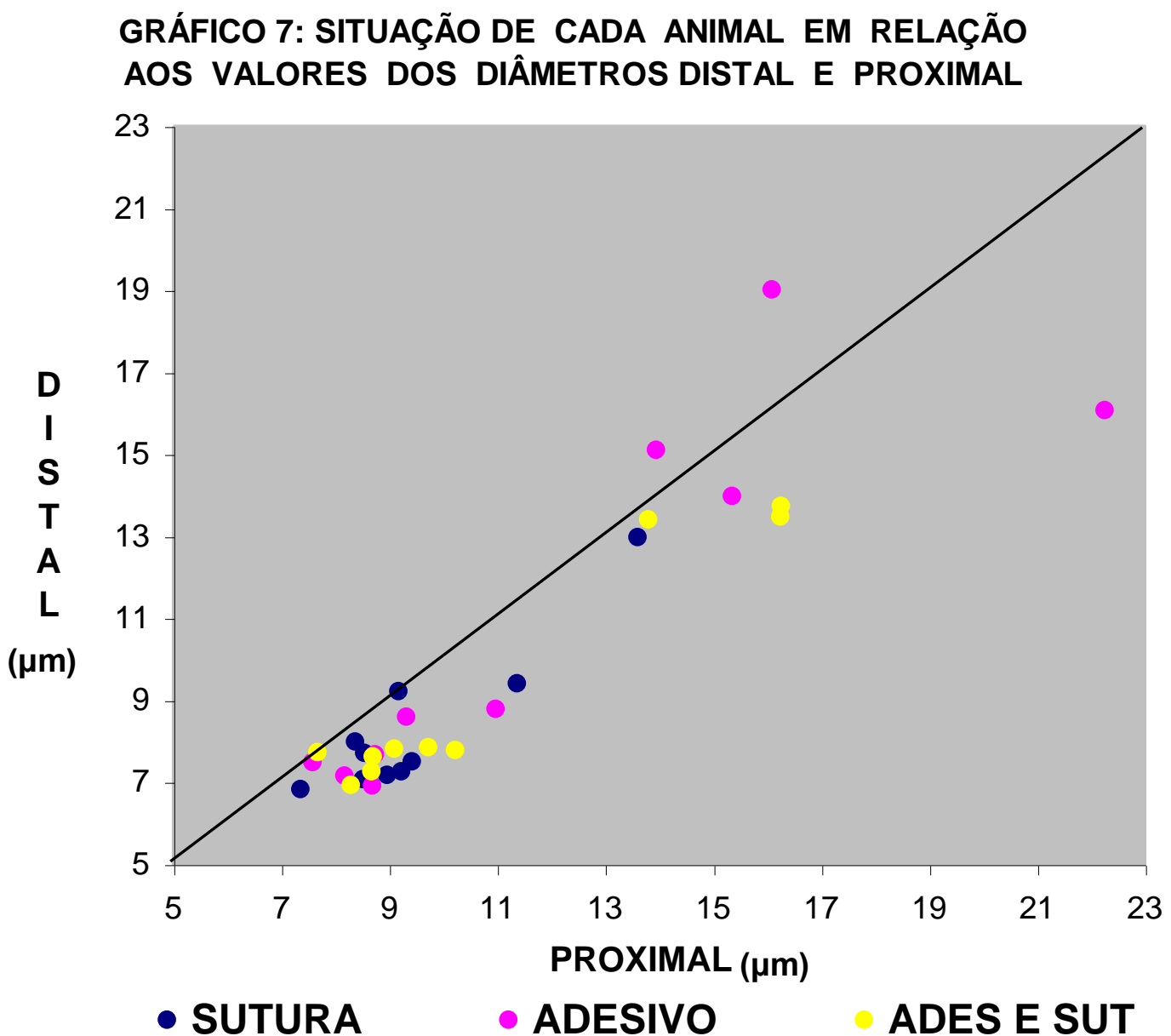

Legenda: Adesivo: grupo de animais submetidos ao reparo com adesivo; Ades e sut: grupo de animais submetidos ao reparo com adesivo e sutura; $\mu \mathrm{m}$ : micrômetro; Sutura: grupo de animais submetidos ao reparo com sutura. 
No gráfico 7 a reta divide o mesmo em duas regiões. Na região inferior estão situados os animais cujo diâmetro proximal é superior ao distal e o contrário ocorre na região superior à reta. Nota-se que, com exceção de três animais pertencentes ao grupo $\mathrm{B}$, a posição dos mesmos em relação à reta é semelhante nos três grupos de reparo. Essa aparente distribuição homogênea foi confirmada com a avaliação estatística.

O IAD variou de $72,04 \%$ a $117,88 \%$ com média de $88,10 \pm 10,03 \%$ nos três grupos. O valor do IAD variou de 78,27 a 99,89 \% com média de $87,32 \pm 7,90 \%$ no grupo A, de 72,04 a 117,88 \% com média de 85,86 \pm 7,36 \% no grupo B e de 75,68 a $100,13 \%$ com média de $85,86 \pm 7,36 \%$ no grupo C. O IAD foi superior a $100 \%$ em três animais, sendo dois do grupo B e um do grupo C. Não houve diferença estatisticamente significativa dos valores do IAD entre os três grupos $(p=0,561)$.

Os valores dos parâmetros obtidos com a avaliação da histomorfometria para cada animal estão relacionados no anexo G. 
6. DISCUSSÃO 


\section{DISCUSSÃO}

Analisando-se de forma global as alterações obtidas nos parâmetros da eletrofisiologia antes e após a cirurgia, nota-se que as modificações ocorreram de forma semelhante de acordo com o grupo de reparo considerado, com exceção da LATN2, da VCM2 e da \%VCM. Na avaliação desses parâmetros foi identificada uma diferença significativa entre os grupos A e B para os três parâmetros e entre os grupos A e C também para a \% VCM.

O fato da melhora ter sido observada apenas com os parâmetros relacionados direta ou indiretamente com a VC pode ser resultante de um processo de mielinização mais eficaz nos axônios regenerados, principalmente quando considerado o grupo B. Resultados semelhantes foram obtidos no estudo de Moy et $\mathrm{al}^{17}$ realizado em coelhos, onde a recuperação da $\mathrm{VC}$ foi superior em relação à amplitude no mesmo período analisado. No estudo desses autores os animais cujos nervos ciáticos foram submetidos ao reparo com adesivo apresentaram recuperação da VC para 97 a $98 \%$ da VC inicial enquanto que a amplitude foi de $40 \%$ da inicial no mesmo período.

Poucos estudos na literatura realizaram uma avaliação eletrofisiológica de forma semelhante ao utilizado nesse estudo onde, para cada animal, foi determinado o valor basal dos parâmetros avaliados. A média dos resultados obtidos na amplitude e VC do PAM antes da secção do nervo foram semelhantes aos obtidos em nervos íntegros por He et $\mathrm{al}^{248}$. Esses autores avaliaram a regeneração no nervo ciático do rato após secção e implante de um condutor com NGF e compararam os resultados da eletromiografia com o nervo contralateral não lesado. Apenas dois estudos que 
avaliaram a eficácia do adesivo no reparo de nervos investigaram o PAM. No estudo de Gilbert não foram informados a metodologia utilizada e os resultados numéricos relacionados a essa investigação ${ }^{20}$. Os resultados da latência do PAM foram semelhantes aos obtidos por Inalöz et $\mathrm{al}^{27}$.

Nos resultados obtidos na avaliação eletrofisiológica verifica-se que em alguns animais houve uma melhora dos parâmetros avaliados em relação ao valor basal. Esse fato pode ser justificado pelo período de observação utilizado neste estudo, uma vez que não há definição na literatura a respeito do tempo exato em que há uma interrupção da recuperação dos parâmetros avaliados após o reparo, em relação a um valor basal. Raros estudos avaliam a recuperação eletrofisiológica após a lesão e reparo em nervos em um período tão prolongado como o utilizado. Cham et $\mathrm{al}^{208}$ compararam a regeneração do nervo ciático do rato após a sua secção e reparo com fio absorvível ou com fio de sutura inabsorvível. A análise eletrofisiológica com a medida da amplitude e VC do potencial de ação motor foi realizada de forma seriada até a vigésima semana após a cirurgia. A VC aumentou de $38 \%$ do valor original após seis semanas até $75 \%$ na vigésima semana. A amplitude aumentou de $3 \%$ para $50 \%$ do valor original no mesmo período. Watanabe et $\mathrm{al}^{249}$ quantificaram de forma seriada diversos parâmetros relacionados à avaliação da regeneração após a sutura no nervo ciático previamente seccionado em ratos neonatos e em ratos jovens, até o décimo quarto mês depois da cirurgia. Na avaliação da VC do PAN, nos dois grupos de animais os valores médios no grupo controle, constituído pelas medidas desse parâmetro no nervo íntegro contralateral no primeiro mês após a cirurgia, foram semelhantes às medidas médias obtidas na avaliação do nervo reparado catorze meses após a cirurgia. 
Uma demonstração do que ocorre temporalmente com um dos parâmetros eletrofisiológicos, quando utilizado o adesivo e a sutura para o reparo do nervo ciático, foi evidenciada por Smahel et $\mathrm{al}^{16}$. No estudo desses autores a latência do PAN, demonstrada graficamente, era cerca de três vezes menor após seis meses do reparo em comparação com o valor obtido após três semanas do mesmo. Nesse mesmo estudo, o valor da amplitude média do PAN foi cerca de doze a dezesseis vezes superior após seis meses do reparo em comparação com o valor obtido após três semanas do mesmo. Com a ressalva de que os valores podem ser obtidos com inferências a partir dos gráficos e a comparação dos valores finais ser realizada com um grupo controle de apenas quatro animais que não foram operados, a \% VCN e a \%AMPN no estudo desses autores apresentam valores muito próximos dos obtidos no presente estudo.

Em apenas outros dois trabalhos dos analisados foram informados os valores médios exatos dos parâmetros obtidos com a avaliação do PAN. O período de observação foi de 20 a 60 dias no estudo de Ratto et al $^{7}$ e de dois meses no de Maragh et $\mathrm{al}^{24}$. No estudo de Ratto et $\mathrm{al}^{7}$, a latência média dos potenciais obtidos no grupo de seis animais cujos nervos foram reparados com sutura, 0,69 ms, foi maior em relação à obtida no presente estudo, cujo valor médio foi de $0,41 \mathrm{~ms}$. Esse valor relatado pelos autores foi significativamente superior em relação aos nove animais onde o reparo do nervo foi realizado com o adesivo, $2,98 \mathrm{~ms}$, e cerca de doze vezes superior à média da latência obtida utilizando-se o mesmo tipo de reparo no presente estudo. No estudo de Maragh et $\mathrm{al}^{24}$, os valores obtidos foram cerca de três vezes inferiores aos obtidos neste estudo e melhores quando o reparo utilizado foi a sutura. 
A diferença observada entre esses valores do PAN e os resultados do presente estudo poderia ser justificada mais uma vez pelo tempo de observação utilizado. Dois meses é o tempo suficiente para que os axônios ultrapassem a região do reparo e atinjam o órgão-alvo porém, a maturação dessas fibras, que inclui o processo de mielinização, pode se completar em um período superior. Além disso, a presença de fibras musculares polineuronalmente inervadas, cuja ocorrência reduz a eficiência final da regeneração e conseqüentemente a transmissão de impulso, se reduz de forma progressiva após a lesão ${ }^{250}$. Assim, ao término de um período de observação prolongado como o utilizado, a maioria das fibras remanescentes apresentaria uma maior qualidade em comparação com o total de fibras presentes em períodos mais curtos de observação.

$\mathrm{Na}$ avaliação histomorfométrica do presente estudo não houve diferença significativa entre os grupos para todos os parâmetros analisados. Portanto, o uso da sutura não representou uma barreira para os axônios em regeneração em comparação com o reparo constituído pelo adesivo e pela combinação das duas técnicas. Em doze animais a contagem dos axônios no segmento distal foi superior ao proximal. Esses resultados estão em conformidade com resultados demonstrados em literatura, onde o número de axônios no coto distal após uma neurorrafia pode ser até $150 \%$ superior em relação ao coto proximal e é justificada pela ocorrência de brotamentos axonais a partir de um único axônio em crescimento ${ }^{178,253}$.

O número total de axônios mensurados no segmento proximal e distal do presente estudo foi superior aos relatados por Maragh et $\mathrm{al}^{24}$ e por Menovsky et $\mathrm{al}^{246}$ e inferiores aos obtidos por Gilbert ${ }^{20}$. Os resultados do IReg no presente estudo foram superiores aos relatados por Maragh et $\mathrm{al}^{24}$ e por Zhang et $\mathrm{al}^{29}$ e inferiores aos 
descritos por Zhou ${ }^{25}$. No presente estudo não houve uma diferença significativa entre os IReg dos grupos A e B, corroborando esses resultados com os descritos por Maragh et $\mathrm{al}^{24}$, Zhang et $\mathrm{al}^{29}$ e Zhou ${ }^{25}$. Ao contrário, Gilbert ${ }^{20}$ descreve uma diferença marcante entre os dois grupos de reparo, com um maior IReg quando o adesivo foi utilizado.

O diâmetro médio dos axônios tanto no segmento proximal como no distal descritos no presente estudo foram superiores aos relatados por Gilbert ${ }^{20}$, Jin et $\mathrm{al}^{23} \mathrm{e}$ Menosky et $\mathrm{al}^{246}$. No presente estudo a medida do diâmetro não apresentou diferença significativa entre os segmentos proximal e distal, o que também ocorreu no estudo de Jin et al, ao contrário do estudo de Menovsky et $\mathrm{al}^{246}$. No estudo desses autores o diâmetro dos axônios no segmento proximal ao reparo foi duas vezes superior em relação ao diâmetro no segmento distal, nos grupos de animais submetidos ao reparo do nervo ciático com sutura e com adesivo e sutura.

No presente estudo, não houve diferença significativa nos três grupos de reparo em relação ao número de axônios extrafasciculares e sua relação com o número total de axônios regenerados no segmento distal do nervo, condizente com a manutenção da organização histológica do nervo. A ausência de diferença significativa entre os três grupos de reparo também foi observada na avaliação dos outros parâmetros histomorfométricos.

Atualmente tem-se dado uma maior importância à precisão da regeneração, avaliada através da análise funcional da marcha, em comparação com a avaliação histomorfométrica. Desde a introdução da avaliação do IFC por De Medinacelli et $\mathrm{al}^{167}$, esse método tem sido utilizado de forma crescente em numerosos estudos para a avaliação funcional da marcha, considerada como a via final da regeneração do 
nervo ciático do rato previamente lesado. Sua aplicação, no entanto, freqüentemente apresenta dificuldades técnicas devido à ocorrência de complicações como retrações e autotomia, apresentadas durante a realização deste estudo.

Em nenhum estudo da literatura que avalia a eficácia do adesivo de fibrina no reparo de nervos, esse método havia sido adotado. No estudo de Sames et $\mathrm{al}^{28}$, a mensuração desse parâmetro, que inicialmente estava no planejamento do estudo, não se realizou devido à ocorrência de algum grau de autotomia nas patas de todos os animais. A presença dessa complicação também dificultou sobremaneira a conclusão do presente estudo.

Como não há trabalhos na literatura avaliando o reparo com adesivo de fibrina através da medida do IFC, a comparação dos resultados obtidos neste estudo só é possível com os de outros estudos que realizaram outros tipos de investigações. O valor do IFC2 no grupo de animais submetidos à sutura foi semelhante ao obtido por Hare et $\mathrm{al}^{170}$ e Shen e $\mathrm{Zhu}^{251}$ no mesmo período analisado. Hare et al ${ }^{170}$ compararam a recuperação do IFC após sutura tradicional em grupos de animais submetidos à secção isolada dos nervos tibial, fibular e ciático. No estudo desses autores o valor médio do IFC foi -59 no mesmo período analisado. Shen e Zhu ${ }^{251}$ mensuraram diversos índices na avaliação da regeneração, entre eles o IFC, em animais submetidos à secção do nervo e reparo com sutura convencional e utilização de enxertos. A média do IFC no grupo onde o reparo foi realizado com sutura foi de 51,56 após seis meses da cirurgia. No presente estudo a comparação dos resultados do IFC2 demonstrou que houve diferença significativa entre os grupos A e B.

Este estudo demonstrou que o reparo com adesivo de fibrina é o método experimental que oferece melhores condições para a regeneração após a secção do 
nervo em comparação com o reparo obtido com a sutura tradicional. Demonstrou também que a utilização do reparo combinado, ao adicionar um ponto ao adesivo, não ocasiona uma piora na regeneração em comparação com o reparo que utilizou o adesivo de forma isolada.

Uma possível explicação para a pior evolução nos animais submetidos a reparo com sutura poderia ser o resultado da combinação de dois fatores. A sutura causaria um processo inflamatório mais exuberante na região periférica do reparo, insuficiente para provocar uma redução no número e diâmetro dos axônios ou um aumento do número de axônios extrafasciculares, quando comparados esses parâmetros com os obtidos nos outros dois grupos de reparo, mas suficiente para causar uma distorção no trajeto desses axônios em direção ao segmento distal do nervo ${ }^{16}$ ou redução do fluxo sangüíneo temporário na microcirculação ${ }^{17}$. Essas alterações poderiam ocasionar dois tipos de modificações na fisiologia das fibras em regeneração. A primeira alteração seria uma redução na transmissão de impulso na região que poderia ser detectada pela avaliação do PAN, mas que não foi observada. A segunda alteração poderia ser representada por um atraso no processo de maturação das fibras nervosas regeneradas nesse grupo. Neste último caso uma subpopulação de fibras musculares, que não foram reinervadas em tempo hábil, sofreria um processo de degeneração. O resultado final seria um número reduzido de fibras musculares inervadas, resultando nas alterações observadas durante a avaliação do PAM. Além disso, a desorganização temporal do processo de regeneração poderia influenciar a aquisição de informação a partir da pata operada, prejudicando a integração central e resultando na diferença obtida durante a avaliação do IFC2 entre os grupos de reparo. Deve-se também considerar que o número de fibras pode não se correlacionar com 
uma recuperação funcional. A regeneração pode ocorrer através de vias inadequadas resultando na inervação de músculos agonistas e antagonistas ${ }^{169}$.

É importante ressaltar que este estudo não se deteve na análise da eficiência imediata da coaptação a partir dos aspectos físicos do reparo. Deve-se considerar a possibilidade de deiscência com o adesivo de fibrina, cuja ocorrência é praticamente nula quando utilizada a sutura convencional de forma exclusiva. Uma possibilidade para explicar a ausência de deiscência no reparo dos nervos do presente estudo foi o sacrifício dos animais que apresentaram complicações. Nestes casos, a regeneração inadequada ou ausente, conseqüente à presença de deiscência, poderia resultar nas alterações observadas nas patas, como a ocorrência de retrações músculo-tendíneas. Fato semelhante pode ter ocorrido com o grupo de animais onde o reparo foi realizado com a sutura convencional, uma vez que em nenhum animal reoperado foi identificado um neuroma na região da sutura.

Alguns fatos devem ser considerados na utilização do adesivo para o reparo de nervos. Ao contrário do adesivo, a eficácia de alinhamento dos cotos é obtida mais facilmente com a sutura e a possibilidade de deiscência com esse método é praticamente nula. Deve-se também atentar para o fato da possibilidade de transmissão de infecção viral quando utilizado o adesivo de fibrina, apesar de todos os cuidados no processo de preparo ao qual o produto é submetido. Além disso, embora não haja relato, o risco de infecção por príons deve ser considerado. Apesar da baixa infectividade desse agente quando proveniente de extratos de pulmões bovinos, o órgão onde é obtida a aprotinina utilizada no adesivo, a possibilidade de transmissão de doença priônica interespécie é fato estabelecido na literatura ${ }^{252}$. 
A aplicação dos resultados deste estudo a situações práticas na cirurgia de nervos requer alguns cuidados. Pelo seu reduzido calibre, o nervo ciático do rato pode ser comparável a alguns nervos que são freqüentemente utilizados no homem, como os nervos intercostais, os digitais, ramos terminais do facial e alguns componentes do plexo braquial ou outros nervos de crianças ou lactentes. Nestes casos, o uso do adesivo pode ser vantajoso uma vez que uma maior reação inflamatória causada pela sutura na periferia do reparo ${ }^{30,}{ }^{235}$, pode ser proporcionalmente importante em relação à área seccional desses elementos. No entanto, em nervos de maior calibre, a maior área de secção transversa seria um fator de proteção relativo quando se utiliza a sutura convencional. Nessas condições, a reação inflamatória não comprometeria de forma significativa a área por onde transitam os axônios em regeneração. Além disso, uma reação inflamatória secundária ao trauma é freqüente e pode ocasionar um espessamento do epineuro. Esse espessamento poderia atuar como um fator protetor na restrição do processo inflamatório relacionado à realização da sutura convencional e, nesses casos, o uso do adesivo com o objetivo de se reduzir a reação inflamatória não se justificaria. 
7. CONCLUSÕES 


\section{CONCLUSÕES}

Os resultados obtidos neste estudo após a realização do reparo do nervo ciático do rato previamente seccionado permitem concluir que:

1. Na avaliação funcional da marcha, os animais onde o reparo foi realizado com o adesivo de fibrina apresentaram melhores resultados em comparação com os animais cujo reparo foi realizado com a sutura. Não houve diferença entre os animais onde o reparo foi realizado com adesivo e com adesivo e sutura.

2. Quando consideradas a latência, a velocidade de condução e a razão entre a velocidade de condução final em relação à inicial, expressa em porcentagem, obtidas na mensuração do potencial de ação motor após 24 semanas de observação, os animais submetidos ao reparo com o adesivo de fibrina apresentaram resultados significativamente melhores quando comparados com os animais cujo reparo foi realizado com a sutura. Os resultados apresentados na avaliação do mesmo parâmetro nos animais cujo reparo foi realizado com a combinação das duas técnicas, quando avaliada a razão entre a velocidade de condução final em relação à inicial expressa em porcentagem, foram significativamente melhores em relação ao grupo de animais onde o reparo foi realizado com sutura.

3. Quando consideradas a mensuração do potencial de ação do nervo e a avaliação histomorfométrica, não houve diferença significativa dos parâmetros obtidos entre o reparo realizado com a sutura, com o adesivo e com a combinação das duas técnicas. 
8. ANEXOS 


\section{ANEXOS}

Anexo A - Etapas do Experimento

Os períodos de observação utilizados neste estudo foram baseados em dados obtidos na literatura. Nos numerosos estudos que utilizam a metodologia de avaliação do IFC, a maioria das avaliações foi realizada até o período de três a quatro meses da lesão ${ }^{172}$. Após este período, a aplicação do IFC demonstra uma variabilidade muito grande, apesar da presença de um número significativo de fibras mielinizadas, devido à ocorrência de contraturas e deformidades na pata operada ${ }^{172}$. Após um ano, a aplicação do teste para a medida do IFC torna-se inviável. De acordo com Hare et al ${ }^{170}$, a recuperação da função do nervo ciático após sua secção e reparo, avaliada através de medidas do IFC de forma seriada, ocorre no período de oito a 24 semanas. Por esses motivos optou-se pela avaliação do IFC após 12 semanas da lesão.

A contagem do número de axônios distal ao local de sutura pode apresentar uma redução de 20 a 40 \% em comparação com o segmento proximal no período de três a seis meses após a lesão ${ }^{253}$. Segundo Mackinnon et $\mathrm{al}^{254}$, o número de fibras no coto distal aumenta com o tempo até o período do terceiro ao sexto mês e, a partir deste período, sofre uma redução progressiva. O diâmetro dessas fibras apresenta um aumento progressivo até se estabilizar 12 meses após a lesão ${ }^{254}$. De acordo com Dellon e Mackinnon ${ }^{169}$, o número de axônios distal a um reparo aumenta dramaticamente decorridos três meses, atinge um platô entre o sexto e o nono mês após o reparo, e retorna ao valor normal cerca de um ano no nervo ciático do rato. Devido a essas informações optou-se pela realização do exame histológico após seis meses da secção do nervo. 
Anexo B - Data e peso dos animais na primeira e segunda cirurgia e o reparo adotado.

\begin{tabular}{|c|c|c|c|c|c|}
\hline ANIMAL & DATA 1 & PESO 1 (grs) & DATA 2 & PESO 2 (grs) & REPARO \\
\hline 4 & $13 / 12 / 2001$ & 310 & $05 / 06 / 2002$ & 500 & $\mathrm{~A}$ \\
\hline 6 & $28 / 12 / 2001$ & 290 & $19 / 06 / 2002$ & 410 & $\mathrm{~B}$ \\
\hline 12 & $18 / 12 / 2001$ & 340 & $19 / 06 / 2002$ & 530 & $\mathrm{~A}$ \\
\hline 13 & $18 / 12 / 2001$ & 310 & $19 / 06 / 2002$ & 390 & $\mathrm{~A}$ \\
\hline 16 & $02 / 01 / 2002$ & 300 & $24 / 06 / 2002$ & 490 & $\mathrm{~B}$ \\
\hline 19 & $28 / 12 / 2001$ & 290 & $24 / 06 / 2002$ & 460 & $\mathrm{~B}$ \\
\hline 22 & $11 / 02 / 2002$ & 290 & $07 / 08 / 2002$ & 560 & $\mathrm{C}$ \\
\hline 24 & $11 / 02 / 2002$ & 280 & $07 / 08 / 2002$ & 510 & $\mathrm{~B}$ \\
\hline 25 & $25 / 04 / 2002$ & 300 & $15 / 10 / 2002$ & 480 & $\mathrm{~B}$ \\
\hline 27 & $25 / 04 / 2002$ & 260 & $15 / 10 / 2002$ & 390 & $\mathrm{C}$ \\
\hline 28 & $20 / 06 / 2002$ & 290 & $17 / 12 / 2002$ & 410 & $\mathrm{C}$ \\
\hline 29 & $20 / 06 / 2002$ & 270 & $17 / 12 / 2002$ & 450 & $\mathrm{C}$ \\
\hline 30 & $20 / 06 / 2002$ & 310 & $17 / 12 / 2002$ & 445 & $\mathrm{C}$ \\
\hline 31 & $19 / 06 / 2002$ & 320 & $17 / 12 / 2002$ & 470 & $\mathrm{~A}$ \\
\hline 32 & $20 / 06 / 2002$ & 315 & $17 / 12 / 2002$ & 475 & $\mathrm{C}$ \\
\hline 33 & $19 / 06 / 2002$ & 300 & $17 / 12 / 2002$ & 475 & $\mathrm{~A}$ \\
\hline 34 & $20 / 06 / 2002$ & 300 & $17 / 12 / 2002$ & 485 & $\mathrm{C}$ \\
\hline 35 & $11 / 09 / 2002$ & 355 & $11 / 03 / 2003$ & 515 & $\mathrm{C}$ \\
\hline 36 & $11 / 09 / 2002$ & 300 & $11 / 03 / 2003$ & 450 & $\mathrm{~B}$ \\
\hline 37 & $11 / 09 / 2002$ & 305 & $11 / 03 / 2003$ & 470 & $\mathrm{~B}$ \\
\hline 38 & $11 / 09 / 2002$ & 360 & $11 / 03 / 2003$ & 540 & $\mathrm{~B}$ \\
\hline 39 & $11 / 09 / 2002$ & 350 & $11 / 03 / 2003$ & 405 & $\mathrm{~B}$ \\
\hline 42 & $02 / 11 / 2002$ & 270 & $29 / 04 / 2003$ & 560 & $\mathrm{~A}$ \\
\hline 43 & $02 / 11 / 2002$ & 275 & $29 / 04 / 2003$ & 500 & $\mathrm{~A}$ \\
\hline 44 & $02 / 11 / 2002$ & 260 & $29 / 04 / 2003$ & 515 & $\mathrm{~A}$ \\
\hline 45 & $02 / 11 / 2002$ & 280 & $29 / 04 / 2003$ & 510 & $\mathrm{~A}$ \\
\hline 46 & $02 / 11 / 2002$ & 280 & $29 / 04 / 2003$ & 585 & $\mathrm{C}$ \\
\hline 47 & $02 / 11 / 2002$ & 280 & $29 / 04 / 2003$ & 545 & $\mathrm{~A}$ \\
\hline 49 & $30 / 01 / 2003$ & 270 & $29 / 07 / 2003$ & 460 & $\mathrm{~B}$ \\
\hline 50 & $30 / 01 / 2003$ & 260 & $29 / 07 / 2003$ & 440 & $\mathrm{C}$ \\
\hline
\end{tabular}

Legenda: A: grupo A - sutura; ANIMAL: número de identificação do animal; B: grupo B adesivo; C: grupo C - adesivo e sutura; DATA 1: data da primeira cirurgia; DATA 2: data da reoperação; gr: gramas; PESO 1: peso na primeira cirurgia; PESO 2: peso na segunda cirurgia; REPARO: tipo de reparo adotado. 
Anexo C - Valores dos parâmetros para o cálculo do índice funcional ciático préoperatório para cada animal de acordo com o grupo de reparo.

\begin{tabular}{|c|c|c|c|c|c|c|c|}
\hline \multicolumn{7}{|c|}{ GRUPO A - SUTURA } \\
\hline \hline ANIMAL & CPD & CPE & DDD & DDE & DID & DIE & IFC1 \\
\hline 4 & 3,30 & 3,40 & 2,40 & 2,40 & 1,10 & 1,10 & $-7,67$ \\
\hline 12 & 3,40 & 3,50 & 2,40 & 2,30 & 1,40 & 1,40 & $-2,94$ \\
\hline 13 & 3,40 & 3,40 & 2,40 & 2,30 & 1,50 & 1,40 & $-3,09$ \\
\hline 31 & 3,40 & 3,30 & 2,10 & 2,10 & 1,30 & 1,30 & $-9,96$ \\
\hline 33 & 3,40 & 3,40 & 2,30 & 2,30 & 1,50 & 1,40 & $-7,85$ \\
\hline 42 & 3,30 & 3,40 & 2,20 & 2,20 & 1,40 & 1,30 & $-6,65$ \\
\hline 43 & 3,30 & 3,40 & 2,00 & 2,00 & 1,10 & 1,00 & $-6,34$ \\
\hline 44 & 3,60 & 3,60 & 2,40 & 2,20 & 1,30 & 1,30 & 1,15 \\
\hline 45 & 3,40 & 3,40 & 2,10 & 1,90 & 1,20 & 1,20 & 2,73 \\
\hline 47 & 3,30 & 3,20 & 2,20 & 2,00 & 1,10 & 1,00 & 2,28 \\
\hline
\end{tabular}

\begin{tabular}{|c|c|c|c|c|c|c|c|}
\hline \multicolumn{7}{|c|}{ GRUPO B - ADESIVO } \\
\hline \hline ANIMAL & CPD & CPE & DDD & DDE & DID & DIE & IFC1 \\
\hline 6 & 3,30 & 3,30 & 2,20 & 2,20 & 1,10 & 1,20 & $-9,91$ \\
\hline 16 & 3,50 & 3,60 & 2,30 & 2,20 & 1,40 & 1,30 & $-1,74$ \\
\hline 19 & 3,40 & 3,50 & 2,20 & 2,20 & 1,20 & 1,30 & $-8,73$ \\
\hline 24 & 3,40 & 3,40 & 2,10 & 2,10 & 1,30 & 1,20 & $-7,69$ \\
\hline 25 & 3,30 & 3,30 & 2,20 & 2,00 & 1,20 & 1,20 & 2,15 \\
\hline 36 & 3,20 & 3,30 & 2,20 & 2,20 & 1,20 & 1,20 & $-7,64$ \\
\hline 37 & 3,30 & 3,40 & 2,20 & 2,10 & 1,20 & 1,10 & $-1,25$ \\
\hline 38 & 3,50 & 3,60 & 2,30 & 2,10 & 1,40 & 1,40 & 2,69 \\
\hline 39 & 3,50 & 3,50 & 2,20 & 2,10 & 1,30 & 1,30 & $-3,59$ \\
\hline 49 & 3,20 & 3,20 & 2,00 & 1,90 & 1,20 & 1,00 & $-0,38$ \\
\hline
\end{tabular}

\begin{tabular}{|c|c|c|c|c|c|c|c|}
\hline \multicolumn{7}{|c|}{ GRUPO C - ADESIVO E SUTURA } \\
\hline \hline ANIMAL & CPD & CPE & DDD & DDE & DID & DIE & IFC1 \\
\hline 22 & 3,50 & 3,60 & 2,00 & 1,90 & 1,00 & 1,00 & $-1,97$ \\
\hline 27 & 3,20 & 3,30 & 1,90 & 1,90 & 1,10 & 1,00 & $-6,31$ \\
\hline 28 & 3,30 & 3,30 & 2,00 & 2,00 & 1,20 & 1,20 & $-8,80$ \\
\hline 29 & 3,40 & 3,30 & 2,10 & 2,10 & 1,30 & 1,20 & $-8,85$ \\
\hline 30 & 3,50 & 3,50 & 2,30 & 2,20 & 1,30 & 1,30 & $-3,82$ \\
\hline 32 & 3,50 & 3,50 & 2,30 & 2,30 & 1,40 & 1,30 & $-7,78$ \\
\hline 34 & 3,40 & 3,30 & 2,20 & 2,10 & 1,30 & 1,20 & $-3,64$ \\
\hline 35 & 3,50 & 3,60 & 2,40 & 2,30 & 1,40 & 1,20 & $-0,76$ \\
\hline 46 & 3,30 & 3,40 & 2,00 & 2,00 & 1,20 & 1,20 & $-7,67$ \\
\hline 50 & 3,20 & 3,30 & 2,20 & 2,00 & 1,10 & 1,00 & 4,64 \\
\hline
\end{tabular}

Legenda:

ANIMAL: número de identificação do animal; CPD: comprimento da pegada da pata direita; CPE: comprimento da pegada da pata esquerda; DDD: distância entre os dedos da pata direita; DDE: distância entre os dedos da pata esquerda; DID: distância entre os dedos intermediários da pata direita; DIE: distância entre os dedos intermediários da pata esquerda; IFC1: índice funcional ciático pré-operatório. 
Anexo D - Valores dos parâmetros para o cálculo do índice funcional ciático pósoperatório para cada animal de acordo com o grupo de reparo.

\begin{tabular}{|c|c|c|c|c|c|c|c|}
\hline \multicolumn{7}{|c|}{ GRUPO A - SUTURA } \\
\hline \hline ANIMAL & CPO & CPN & DDO & DDN & DIO & DIN & IFC2 \\
\hline 4 & 4,0 & 3,9 & 1,5 & 2,1 & 1,3 & 1,4 & $-42,02$ \\
\hline 12 & 3,6 & 3,5 & 1,7 & 2,4 & 1,1 & 1,6 & $-45,99$ \\
\hline 13 & 3,0 & 3,4 & 1,4 & 2,1 & 0,9 & 1,1 & $-43,21$ \\
\hline 31 & 3,9 & 3,7 & 1,3 & 1,9 & 0,9 & 1,0 & $-46,78$ \\
\hline 33 & 3,3 & 3,2 & 1,2 & 2,0 & 1,0 & 1,1 & $-55,01$ \\
\hline 42 & 3,7 & 3,8 & 1,3 & 2,1 & 1,1 & 1,3 & $-51,55$ \\
\hline 43 & 3,8 & 3,6 & 1,3 & 2,3 & 1,0 & 1,4 & $-62,34$ \\
\hline 44 & 3,8 & 3,3 & 1,2 & 2,1 & 1,0 & 1,3 & $-64,60$ \\
\hline 45 & 3,3 & 3,2 & 1,4 & 2,3 & 1,0 & 1,4 & $-56,65$ \\
\hline 47 & 3,8 & 3,4 & 1,6 & 2,3 & 1,0 & 1,4 & $-50,43$ \\
\hline
\end{tabular}

\begin{tabular}{|c|c|c|c|c|c|c|c|}
\hline \multicolumn{7}{|c|}{ GRUPO B - ADESIVO } \\
\hline \hline ANIMAL & CPO & CPN & DDO & DDN & DIO & DIN & IFC2 \\
\hline 6 & 3,5 & 4,0 & 1,5 & 2,0 & 1,0 & 1,5 & $-35,82$ \\
\hline 16 & 3,6 & 3,7 & 1,7 & 2,2 & 0,9 & 1,2 & $-35,98$ \\
\hline 19 & 3,5 & 3,5 & 1,5 & 2,2 & 0,9 & 1,1 & $-46,06$ \\
\hline 24 & 3,5 & 3,5 & 2,3 & 2,5 & 1,6 & 1,7 & $-18,34$ \\
\hline 25 & 4,2 & 3,7 & 1,4 & 1,6 & 0,8 & 1,3 & $-32,78$ \\
\hline 36 & 3,4 & 3,2 & 1,5 & 2,0 & 1,0 & 1,2 & $-40,79$ \\
\hline 37 & 3,7 & 3,4 & 1,4 & 2,2 & 1,0 & 1,1 & $-53,21$ \\
\hline 38 & 4,0 & 3,9 & 1,9 & 2,4 & 1,3 & 1,5 & $-34,37$ \\
\hline 39 & 4,0 & 3,4 & 1,5 & 2,1 & 1,0 & 1,3 & $-49,91$ \\
\hline 49 & 3,7 & 3,6 & 1,5 & 2,0 & 1,1 & 1,3 & $-39,29$ \\
\hline
\end{tabular}

\begin{tabular}{|c|c|c|c|c|c|c|c|}
\hline \multicolumn{9}{|c|}{ GRUPO C - ADESIVO E SUTURA } \\
\hline \hline ANIMAL & CPO & CPN & DDO & DDN & DIO & DIN & IFC2 \\
\hline 22 & 3,7 & 3,6 & 1,5 & 2,0 & 1,2 & 1,3 & $-38,26$ \\
\hline 27 & 3,9 & 3,7 & 1,4 & 1,6 & 0,8 & 1,3 & $-29,67$ \\
\hline 28 & 3,6 & 3,2 & 1,6 & 2,1 & 0,8 & 1,1 & $-43,29$ \\
\hline 29 & 3,3 & 3,5 & 1,4 & 2,1 & 1,3 & 1,2 & $-42,00$ \\
\hline 30 & 4,2 & 4,0 & 1,3 & 2,0 & 0,9 & 1,0 & $-50,37$ \\
\hline 32 & 3,3 & 3,6 & 1,3 & 1,9 & 1,0 & 1,2 & $-42,40$ \\
\hline 34 & 3,5 & 3,3 & 1,1 & 2,2 & 0,9 & 1,2 & $-69,20$ \\
\hline 35 & 4,0 & 3,5 & 1,9 & 2,2 & 1,5 & 1,2 & $-25,88$ \\
\hline 46 & 3,7 & 3,6 & 1,3 & 2,3 & 1,1 & 1,4 & $-60,32$ \\
\hline 50 & 3,5 & 3,3 & 1,6 & 2,2 & 0,9 & 1,1 & $-43,40$ \\
\hline
\end{tabular}

Legenda:

ANIMAL: número de identificação do animal; CPO: comprimento da pegada da pata no lado operado; CPN: comprimento da pegada da pata no lado não operado; DDO: distância entre os dedos da pata no lado operado; DDN: distância entre os dedos da pata no lado não operado; DIO: distância entre os dedos intermediários da pata no lado operado; DIN: distância entre os dedos intermediários da pata no lado não operado; IFC2: índice funcional ciático pós-operatório. 
Anexo E - Valores dos parâmetros do potencial de ação do nervo para cada animal de acordo com o grupo de reparo

\begin{tabular}{|c|c|c|c|c|c|c|c|r|}
\hline \multicolumn{7}{|c|}{ GRUPO A - SUTURA } \\
\hline N. & $\begin{array}{c}\text { LATN1 } \\
(\mathrm{ms})\end{array}$ & $\begin{array}{c}\text { LATN2 } \\
(\mathrm{ms})\end{array}$ & $\begin{array}{c}\text { VCN1 } \\
(\mathrm{m} / \mathrm{s})\end{array}$ & $\begin{array}{c}\text { VCN2 } \\
(\mathrm{m} / \mathrm{s})\end{array}$ & $\begin{array}{c}\text { AMPN1 } \\
(\mathrm{mV})\end{array}$ & $\begin{array}{c}\text { AMPN2 } \\
(\mathrm{mV})\end{array}$ & $\%$ VCN & $\%$ AMPN \\
\hline 4 & 0,27 & 0,62 & 74,07 & 32,26 & 1,90 & 0,70 & $43,55 \%$ & $36,63 \%$ \\
\hline 12 & 0,31 & 0,75 & 64,52 & 26,67 & 0,90 & 0,21 & $41,33 \%$ & $23,11 \%$ \\
\hline 13 & 0,29 & 0,58 & 68,97 & 34,48 & 1,40 & 0,53 & $50,00 \%$ & $37,50 \%$ \\
\hline 31 & 0,21 & 0,29 & 95,24 & 68,97 & 1,70 & 0,43 & $72,41 \%$ & $25,29 \%$ \\
\hline 33 & 0,17 & 0,33 & 117,65 & 60,61 & 2,30 & 0,85 & $51,52 \%$ & $37,13 \%$ \\
\hline 42 & 0,20 & 0,25 & 100,00 & 80,00 & 2,00 & 0,11 & $80,00 \%$ & $5,50 \%$ \\
\hline 43 & 0,50 & 0,62 & 40,00 & 32,26 & 0,48 & 0,41 & $80,65 \%$ & $85,42 \%$ \\
\hline 44 & 0,25 & 0,21 & 80,00 & 95,24 & 1,00 & 0,11 & $119,05 \%$ & $11,00 \%$ \\
\hline 45 & 0,23 & 0,27 & 86,96 & 74,07 & 0,75 & 0,26 & $85,19 \%$ & $34,36 \%$ \\
\hline 47 & 0,15 & 0,22 & 133,33 & 90,91 & 0,45 & 0,15 & $68,18 \%$ & $33,33 \%$ \\
\hline
\end{tabular}

\begin{tabular}{|c|c|c|c|c|c|c|c|c|}
\hline \multicolumn{7}{|c|}{ GRUPO B - ADESIVO } \\
\hline N. & $\begin{array}{c}\text { LATN1 } \\
(\mathrm{ms})\end{array}$ & $\begin{array}{c}\text { LATN2 } \\
(\mathrm{ms})\end{array}$ & $\begin{array}{c}\text { VCN1 } \\
(\mathrm{m} / \mathrm{s})\end{array}$ & $\begin{array}{c}\text { VCN2 } \\
(\mathrm{m} / \mathrm{s})\end{array}$ & $\begin{array}{c}\text { AMPN1 } \\
(\mathrm{mV})\end{array}$ & $\begin{array}{c}\text { AMPN2 } \\
(\mathrm{mV})\end{array}$ & $\%$ VCN & $\%$ AMPN \\
\hline 6 & 0,58 & 0,37 & 34,48 & 54,05 & 2,35 & 0,44 & $156,76 \%$ & $18,68 \%$ \\
\hline 16 & 0,15 & 0,29 & 133,33 & 68,97 & 0,77 & 0,39 & $51,72 \%$ & $50,98 \%$ \\
\hline 19 & 0,29 & 0,23 & 68,97 & 86,96 & 1,40 & 0,16 & $126,09 \%$ & $11,36 \%$ \\
\hline 24 & 0,20 & 0,35 & 100,00 & 57,14 & 0,83 & 1,00 & $57,14 \%$ & $121,21 \%$ \\
\hline 25 & 0,25 & 0,67 & 80,00 & 29,85 & 0,65 & 1,09 & $37,31 \%$ & $167 ., 9 \%$ \\
\hline 36 & 0,38 & 0,42 & 52,63 & 47,62 & 1,90 & 0,11 & $90,48 \%$ & $5,79 \%$ \\
\hline 37 & 0,15 & 0,18 & 133,33 & 111,11 & 1,05 & 1,00 & $83,33 \%$ & $95,24 \%$ \\
\hline 38 & 0,57 & 0,46 & 35,09 & 43,48 & 0,42 & 0,59 & $123,91 \%$ & $140,24 \%$ \\
\hline 39 & 0,19 & 0,17 & 105,26 & 117,65 & 1,00 & 1,80 & $111,76 \%$ & $180,00 \%$ \\
\hline 49 & 0,24 & 0,27 & 83,33 & 74,07 & 1,10 & 0,41 & $88,89 \%$ & $37,27 \%$ \\
\hline
\end{tabular}

Legenda: AMPN1: amplitude pré-operatória do potencial de ação do nervo; AMPN2: amplitude pós-operatória do potencial de ação do nervo; LATN1: latência pré-operatória do potencial de ação do nervo; LATN2: latência pós-operatória do potencial de ação do nervo; N.: número de identificação do animal; \%VCN: porcentagem da velocidade de condução pós-operatória em relação à pré-operatória; \%AMPN: porcentagem da amplitude pósoperatória em relação à pré-operatória; $\mathrm{VCN} 1$ : velocidade pré-operatória do potencial de ação do nervo; VCN2: velocidade pós-operatória do potencial de ação do nervo. 
Anexo E - Valores dos parâmetros do potencial de ação do nervo para cada animal de acordo com o grupo de reparo

\begin{tabular}{|c|c|c|c|c|c|c|c|c|}
\hline \multicolumn{10}{|c|}{ GRUPO C-ADESIVO E SUTURA } \\
\hline N. & $\begin{array}{c}\text { LATN1 } \\
(\mathrm{ms})\end{array}$ & $\begin{array}{c}\text { LATN2 } \\
(\mathrm{ms})\end{array}$ & $\begin{array}{c}\text { VCN1 } \\
(\mathrm{m} / \mathrm{s})\end{array}$ & $\begin{array}{c}\text { VCN2 } \\
(\mathrm{m} / \mathrm{s})\end{array}$ & $\begin{array}{c}\text { AMPN1 } \\
(\mathrm{mV})\end{array}$ & $\begin{array}{c}\text { AMPN2 } \\
(\mathrm{mV})\end{array}$ & $\%$ VCN & $\%$ AMPN \\
\hline 22 & 0,31 & 0,54 & 64,52 & 37,04 & 0,90 & 0,20 & $57,41 \%$ & $21,71 \%$ \\
\hline 27 & 0,27 & 0,21 & 74,07 & 95,24 & 0,46 & 0,80 & $128,57 \%$ & $173,04 \%$ \\
\hline 28 & 0,38 & 0,31 & 52,63 & 64,52 & 0,56 & 0,43 & $122,58 \%$ & $76,25 \%$ \\
\hline 29 & 0,17 & 0,29 & 117,65 & 68,97 & 1,40 & 0,66 & $58,62 \%$ & $47,07 \%$ \\
\hline 30 & 0,19 & 0,35 & 105,26 & 57,14 & 1,80 & 0,04 & $54,29 \%$ & $2,03 \%$ \\
\hline 32 & 0,15 & 0,33 & 133,33 & 60,61 & 2,10 & 0,28 & $45,45 \%$ & $13,38 \%$ \\
\hline 34 & 0,21 & 0,25 & 95,24 & 80,00 & 1,30 & 0,47 & $84,00 \%$ & $36,08 \%$ \\
\hline 35 & 0,34 & 0,35 & 58,82 & 57,14 & 1,50 & 1,11 & $97,14 \%$ & $74,00 \%$ \\
\hline 46 & 0,16 & 0,21 & 125,00 & 95,24 & 0,66 & 0,12 & $76,19 \%$ & $18,51 \%$ \\
\hline 50 & 0,21 & 0,43 & 95,24 & 46,51 & 0,77 & 0,44 & $48,84 \%$ & $56,57 \%$ \\
\hline
\end{tabular}

Legenda: AMPN1: amplitude pré-operatória do potencial de ação do nervo; AMPN2: amplitude pós-operatória do potencial de ação do nervo; LATN1: latência pré-operatória do potencial de ação do nervo; LATN2: latência pós-operatória do potencial de ação do nervo; N.: número de identificação do animal; \%VCN: porcentagem da velocidade de condução pós-operatória em relação à pré-operatória; \%AMPN: porcentagem da amplitude pósoperatória em relação à pré-operatória; $\mathrm{VCN} 1$ : velocidade pré-operatória do potencial de ação do nervo; VCN2: velocidade pós-operatória do potencial de ação do nervo. 
Anexo F - Valores dos parâmetros do potencial de ação motor para cada animal de acordo com o grupo de reparo

\begin{tabular}{|c|c|c|c|c|c|c|c|c|}
\hline \multicolumn{7}{|c|}{ GRUPO A - SUTURA } \\
\hline N. & $\begin{array}{c}\text { LATM1 } \\
(\mathrm{ms})\end{array}$ & $\begin{array}{c}\text { LATM2 } \\
(\mathrm{ms})\end{array}$ & $\begin{array}{c}\text { VCM1 } \\
(\mathrm{m} / \mathrm{s})\end{array}$ & $\begin{array}{c}\text { VCM2 } \\
(\mathrm{m} / \mathrm{s})\end{array}$ & $\begin{array}{c}\text { AMPM1 } \\
(\mathrm{mV})\end{array}$ & $\begin{array}{c}\text { AMPM2 } \\
(\mathrm{mV})\end{array}$ & $\%$ VCM & $\%$ AMPM \\
\hline 4 & 1,43 & 2,70 & 20,98 & 11,11 & 5,80 & 1,60 & $52,96 \%$ & $27,59 \%$ \\
\hline 12 & 1,41 & 1,83 & 21,28 & 16,39 & 1,80 & 0,48 & $77,05 \%$ & $26,44 \%$ \\
\hline 13 & 1,35 & 1,92 & 22,22 & 15,63 & 0,72 & 1,30 & $70,31 \%$ & $179,81 \%$ \\
\hline 31 & 1,29 & 1,79 & 23,26 & 16,76 & 0,79 & 2,80 & $72,07 \%$ & $353,09 \%$ \\
\hline 33 & 1,25 & 2,80 & 24,00 & 10,71 & 3,50 & 7,70 & $44,64 \%$ & $220,00 \%$ \\
\hline 42 & 1,75 & 2,90 & 17,14 & 10,34 & 8,30 & 5,40 & $60,34 \%$ & $65,06 \%$ \\
\hline 43 & 1,56 & 2,10 & 19,23 & 14,29 & 5,70 & 4,70 & $74,29 \%$ & $82,46 \%$ \\
\hline 44 & 1,62 & 1,72 & 18,52 & 17,44 & 7,60 & 6,50 & $94,19 \%$ & $85,53 \%$ \\
\hline 45 & 1,46 & 1,70 & 20,55 & 17,65 & 9,60 & 5,50 & $85,88 \%$ & $57,29 \%$ \\
\hline 47 & 1,71 & 1,79 & 17,54 & 16,76 & 7,40 & 6,00 & $95,53 \%$ & $81,08 \%$ \\
\hline
\end{tabular}

\begin{tabular}{|c|c|c|c|c|c|c|c|c|}
\hline \multicolumn{7}{|c|}{ GRUPO B - ADESIVO } \\
\hline N. & $\begin{array}{c}\text { LATM1 } \\
(\mathrm{ms})\end{array}$ & $\begin{array}{c}\text { LATM2 } \\
(\mathrm{ms})\end{array}$ & $\begin{array}{c}\text { VCM1 } \\
(\mathrm{m} / \mathrm{s})\end{array}$ & $\begin{array}{c}\text { VCM2 } \\
(\mathrm{m} / \mathrm{s})\end{array}$ & $\begin{array}{c}\text { AMPM1 } \\
(\mathrm{mV})\end{array}$ & $\begin{array}{c}\text { AMPM2 } \\
(\mathrm{mV})\end{array}$ & $\%$ VCM & $\%$ AMPM \\
\hline 6 & 1,30 & 1,65 & 23,08 & 18,18 & 6,90 & 2,86 & $78,79 \%$ & $41,45 \%$ \\
\hline 16 & 1,70 & 1,96 & 17,65 & 15,31 & 4,80 & 5,70 & $86,73 \%$ & $118,75 \%$ \\
\hline 19 & 1,50 & 2,00 & 20,00 & 15,00 & 4,10 & 1,30 & $75,00 \%$ & $31,71 \%$ \\
\hline 24 & 1,65 & 1,67 & 18,18 & 17,96 & 7,30 & 5,60 & $98,80 \%$ & $76,71 \%$ \\
\hline 25 & 1,64 & 1,58 & 18,29 & 18,99 & 5,70 & 8,20 & $103,80 \%$ & $143,86 \%$ \\
\hline 36 & 1,29 & 1,96 & 23,26 & 15,31 & 3,40 & 3,90 & $65,82 \%$ & $114,71 \%$ \\
\hline 37 & 1,75 & 1,46 & 17,14 & 20,55 & 6,70 & 6,50 & $119,86 \%$ & $97,01 \%$ \\
\hline 38 & 1,47 & 1,83 & 20,41 & 16,39 & 6,80 & 4,20 & $80,33 \%$ & $61,76 \%$ \\
\hline 39 & 1,38 & 1,62 & 21,74 & 18,52 & 2,30 & 6,70 & $85,19 \%$ & $291,30 \%$ \\
\hline 49 & 1,45 & 1,65 & 20,69 & 18,18 & 3,50 & 4,56 & $87,88 \%$ & $130,29 \%$ \\
\hline
\end{tabular}

Legenda: AMPM1: amplitude pré-operatória do potencial de ação motor; AMPM2: amplitude pós-operatória do potencial de ação motor; LATM1: latência pré-operatória do potencial de ação motor; LATM2: latência pós-operatória do potencial de ação motor; N.: número de identificação do animal; \%VCM: porcentagem da velocidade de condução pósoperatória em relação à pré-operatória; \%AMPM: porcentagem da amplitude pós-operatória em relação à pré-operatória; VCM1: velocidade pré-operatória do potencial de ação motor; VCM2: velocidade pós-operatória do potencial de ação motorr. 
Anexo F - Valores dos parâmetros do potencial de ação motor para cada animal de acordo com o grupo de reparo

\begin{tabular}{|c|c|c|c|c|c|c|c|c|}
\hline \multicolumn{7}{|c|}{ GRUPO C-ADESIVO E SUTURA } \\
\hline N. & $\begin{array}{c}\text { LATM1 } \\
(\mathrm{ms})\end{array}$ & $\begin{array}{c}\text { LATM2 } \\
(\mathrm{ms})\end{array}$ & $\begin{array}{c}\text { VCM1 } \\
(\mathrm{m} / \mathrm{s})\end{array}$ & $\begin{array}{c}\text { VCM2 } \\
(\mathrm{m} / \mathrm{s})\end{array}$ & $\begin{array}{c}\text { AMPM1 } \\
(\mathrm{mV})\end{array}$ & $\begin{array}{c}\text { AMPM2 } \\
(\mathrm{mV})\end{array}$ & $\%$ VCM & $\%$ AMPM \\
\hline 22 & 1,83 & 1,62 & 16,39 & 18,52 & 6,90 & 2,70 & $112,96 \%$ & $39,13 \%$ \\
\hline 27 & 2,20 & 1,96 & 13,64 & 15,31 & 3,10 & 4,30 & $112,24 \%$ & $138,71 \%$ \\
\hline 28 & 1,75 & 2,20 & 17,14 & 13,64 & 3,50 & 2,40 & $79,55 \%$ & $68,57 \%$ \\
\hline 29 & 1,29 & 1,60 & 23,26 & 18,75 & 5,60 & 3,00 & $80,63 \%$ & $53,57 \%$ \\
\hline 30 & 1,33 & 1,54 & 22,56 & 19,48 & 3,90 & 2,50 & $86,36 \%$ & $64,10 \%$ \\
\hline 32 & 1,62 & 2,20 & 18,52 & 13,64 & 6,30 & 4,50 & $73,64 \%$ & $71,43 \%$ \\
\hline 34 & 1,21 & 1,70 & 24,79 & 17,65 & 4,40 & 7,10 & $71,18 \%$ & $161,36 \%$ \\
\hline 35 & 1,29 & 1,71 & 23,26 & 17,54 & 4,20 & 6,80 & $75,44 \%$ & $161,90 \%$ \\
\hline 46 & 2,20 & 2,10 & 13,64 & 14,29 & 3,20 & 4,20 & $104,76 \%$ & $131,25 \%$ \\
\hline 50 & 1,96 & 1,84 & 15,31 & 16,30 & 5,40 & 3,30 & $106,52 \%$ & $61,11 \%$ \\
\hline
\end{tabular}

Legenda: AMPM1: amplitude pré-operatória do potencial de ação motor; AMPM2: amplitude pós-operatória do potencial de ação motor; LATM1: latência pré-operatória do potencial de ação motor; LATM2: latência pós-operatória do potencial de ação motor; N.: número de identificação do animal; \%VCM: porcentagem da velocidade de condução pósoperatória em relação à pré-operatória; \%AMPM: porcentagem da amplitude pós-operatória em relação à pré-operatória; VCM1: velocidade pré-operatória do potencial de ação motor; VCM2: velocidade pós-operatória do potencial de ação motor. 
Anexo $\mathrm{G}$ - Resultados da Histomorfometria para cada animal de acordo com o grupo de reparo.

\begin{tabular}{|c|c|c|c|c|c|c|c|c|}
\hline \multicolumn{9}{|c|}{ GRUPO A - SUTURA } \\
\hline $\mathbf{N}$ & $\begin{array}{c}\text { AX } \\
\text { PROX }\end{array}$ & $\begin{array}{c}\text { AX } \\
\text { DIST }\end{array}$ & IReg & $\begin{array}{c}\text { AX } \\
\text { EXTRA }\end{array}$ & IRE & $\begin{array}{c}\text { D } \\
\text { PROX }\end{array}$ & D DIST & IAD \\
\hline 4 & 11085 & 3542 & $32,0 \%$ & 380 & $10,73 \%$ & 11,39 & 9,38 & $82,35 \%$ \\
\hline 12 & 9077 & 8651 & $95,3 \%$ & 1463 & $16,91 \%$ & 9,19 & 9,18 & $99,89 \%$ \\
\hline 13 & 12775 & 9391 & $73,5 \%$ & 170 & $1,81 \%$ & 13,63 & 12,94 & $94,94 \%$ \\
\hline 31 & 10747 & 11170 & $103,9 \%$ & 703 & $6,29 \%$ & 8,39 & 7,96 & $94,87 \%$ \\
\hline 33 & 10132 & 11905 & $117,5 \%$ & 1832 & $15,39 \%$ & 8,99 & 7,14 & $79,42 \%$ \\
\hline 42 & 12082 & 9452 & $78,2 \%$ & 318 & $3,36 \%$ & 7,38 & 6,80 & $92,14 \%$ \\
\hline 43 & 10113 & 10227 & $101,1 \%$ & 592 & $5,79 \%$ & 9,44 & 7,47 & $79,13 \%$ \\
\hline 44 & 12248 & 12252 & $100,0 \%$ & 4 & $0,03 \%$ & 8,56 & 7,68 & $89,72 \%$ \\
\hline 45 & 11524 & 11128 & $96,6 \%$ & 1568 & $14,09 \%$ & 8,54 & 7,04 & $82,44 \%$ \\
\hline 47 & 10768 & 12289 & $114,1 \%$ & 2313 & $18,82 \%$ & 9,25 & 7,24 & $78,27 \%$ \\
\hline \multicolumn{9}{|c|}{ GRUPO B - ADESIVO } \\
\hline $\mathbf{N}$ & $\begin{array}{c}\text { AX } \\
\text { PROX }\end{array}$ & $\begin{array}{c}\text { AX } \\
\text { DIST }\end{array}$ & IReg & $\begin{array}{c}\text { AX } \\
\text { EXTRA }\end{array}$ & IRE & $\begin{array}{c}\text { D } \\
\text { PROX }\end{array}$ & D DIST & IAD \\
\hline 6 & 16603 & 11232 & $67,7 \%$ & 51 & $0,45 \%$ & 13,97 & 15,07 & $107,87 \%$ \\
\hline 16 & 8039 & 10161 & $126,4 \%$ & 972 & $9,57 \%$ & 11,00 & 8,75 & $79,55 \%$ \\
\hline 19 & 13239 & 11103 & $83,9 \%$ & 602 & $5,42 \%$ & 15,37 & 13,95 & $90,76 \%$ \\
\hline 24 & 11533 & 11648 & $101,0 \%$ & 945 & $8,11 \%$ & 22,28 & 16,05 & $72,04 \%$ \\
\hline 25 & 15009 & 8759 & $58,4 \%$ & 1508 & $17,22 \%$ & 16,11 & 18,99 & $117,88 \%$ \\
\hline 36 & 11760 & 11989 & $101,9 \%$ & 3 & $0,03 \%$ & 8,19 & 7,13 & $87,06 \%$ \\
\hline 37 & 11340 & 12847 & $113,3 \%$ & 124 & $0,97 \%$ & 7,60 & 7,45 & $98,03 \%$ \\
\hline 38 & 12150 & 12935 & $106,5 \%$ & 479 & $3,70 \%$ & 8,71 & 6,88 & $78,99 \%$ \\
\hline 39 & 10115 & 11095 & $109,7 \%$ & 1769 & $15,94 \%$ & 8,76 & 7,65 & $87,33 \%$ \\
\hline 49 & 10737 & 10246 & $95,4 \%$ & 1725 & $16,84 \%$ & 9,34 & 8,57 & $91,76 \%$ \\
\hline \multicolumn{9}{|c|}{ GRUPO C - ADESIVO E SUTURA } \\
\hline $\mathbf{N}$ & $\begin{array}{c}\text { AX } \\
\text { PROX }\end{array}$ & $\begin{array}{c}\text { AX } \\
\text { DIST }\end{array}$ & IReg & $\begin{array}{c}\text { AX } \\
\text { EXTRA }\end{array}$ & IRE & $\begin{array}{c}\text { D } \\
\text { PROX }\end{array}$ & D DIST & IAD \\
\hline 22 & 11337 & 9476 & $83,6 \%$ & 1414 & $14,92 \%$ & 16,28 & 13,7 & $84,15 \%$ \\
\hline 27 & 10005 & 10816 & $108,1 \%$ & 509 & $4,71 \%$ & 10,24 & 7,75 & $75,68 \%$ \\
\hline 28 & 13178 & 10754 & $81,6 \%$ & 132 & $1,23 \%$ & 13,82 & 13,38 & $96,82 \%$ \\
\hline 29 & 11257 & 11189 & $99,4 \%$ & 256 & $2,29 \%$ & 16,27 & 13,45 & $82,67 \%$ \\
\hline 30 & 14918 & 9151 & $61,3 \%$ & 242 & $2,64 \%$ & 8,69 & 7,24 & $83,31 \%$ \\
\hline 32 & 16057 & 11674 & $72,7 \%$ & 59 & $0,51 \%$ & 7,69 & 7,70 & $100,13 \%$ \\
\hline 34 & 14263 & 10767 & $75,5 \%$ & 7 & $0,07 \%$ & 8,72 & 7,59 & $87,04 \%$ \\
\hline 35 & 12561 & 11291 & $89,9 \%$ & 224 & $1,98 \%$ & 9,75 & 7,82 & $80,21 \%$ \\
\hline 46 & 13646 & 12077 & $88,5 \%$ & 0 & $0,00 \%$ & 8,31 & 6,91 & $83,15 \%$ \\
\hline 50 & 11142 & 12496 & $112,2 \%$ & 2821 & $22,58 \%$ & 9,11 & 7,78 & $85,40 \%$ \\
\hline
\end{tabular}

Legenda: AX DIST: número de axônios distal ao reparo; AX EXTRA: número de axônios extrafasciculares distal ao reparo; AX PROX: número de axônios proximal ao reparo; D DIST: diâmetro dos axônios na região distal ao reparo; D PROX: diâmetro dos axônios na região proximal ao reparo; IAD: índice de alteração do diâmetro; IReg: índice de regeneração; N: número de identificação do animal. 
9. REFERÊNCIAS 


\section{REFERÊNCIAS}

1.Wilgis EFS. Epineurial repair: technique and long-term results. In: Omer Jr GE, Spinner M, Van Beek AL, editores. Management of peripheral nerve problems. Philadelphia: WB Saunders Company; 1998. p.271-3.

2.Young JZ, Medawar PB. Fibrin suture of peripheral nerves. Lancet. 1940;2:126-7.

3.Tarlov IM, Benjamin B. Plasma clot and silk suture of nerves. Surg Gynecol Obstet. 1943;76:366-74.

4.Seddon HJ, Medawar PB. Fibrin suture of human nerves. Lancet. 1942;2:87-8.

5.Ventura R, Torri G, Campari A, Giandomenico A, Peretti G. Experimental suture of the peripheral nerves with “fibrin glue”. Ital J Orthop Traumatol. 1980;6:40714.

6.Bignotti B. Osservazione sull’uso della colla di fibrina in chirurgia nervosa esperimentale. Ort Traum Oggi. 1982;2:106-9.

7.Ratto S, Bignotti B, Federici A, Rossi F. Osservazioni sull’uso della colla di fibrina in chirurgia nervosa esperimentale: rilievi elettrofisiologici. Ort Traum Oggi. 1982;2:110-3. 
8.Ventura R, Confalonieri N. L'impiego del tissucol nella riparazione delle lesioni nervose: ricerche sperimentali. Ort Traum Oggi. 1982;2:113-5.

9.Boedts D, Bouckaert JI. Anastomoses nerveuses. Sutures ou colle de fibrinogène? Résultats préliminaires. Acta Otorhinolaryngol Belg. 1984;38:107-112.

10. Faldini A, Puntoni P, Magherini PC, Lisanti M, Carlucci F, Risaliti R. Comparative neurophysiological assessments of nerve sutures performed by microsurgical methods and with fibrin glue: experimental study. Ital J Orthop Traumatol. 1984;10:527-32.

11. Becker CM, Gueuning CO, Graff GL. Sutures or fibrin glue for divided rat nerves: Schwann cell and muscle metabolism. Microsurgery. 1985;6:1-10.

12. Cruz NI, Debs N, Fiol RE. Evaluation of fibrin glue in rat sciatic nerve repairs. Plast Reconstr Surg. 1986;78:369-73.

13. Feldman MD, Sataloff RT, Epstein G, Ballas SK. Autologous fibrin tissue adhesive for peripheral nerve anastomosis. Arch Otolaryngol Head Neck Surg. 1987;113:963-7.

14. Hamm KD, Steube D, Beer R, Pothe H. Microsurgical suture and fibrin glueing of nerve anastomoses. Animal experiment study using Cohn I human plasma fraction. Zentralbl Neurochir. 1987;48:206-18. 
15. Merle M, Becker C, Pankovic C, Bagot D'Arc M. Microsurgical repair of peripheral nerves and vessels using Tissucol. Clinical and experimental study. Rev Laryngol Otol Rhinol (Bord). 1987;108:13-4.

16. Smahel J, Meyer VE, Bachem U. Glueing of peripheral nerves with fibrin: experimental studies. J Reconstr Microsurg. 1987;3:211-20.

17. Moy LJ, Peimer CA, Konjuch MP, Howard C, Zielezny M, Katikaneni PR. Fibrin seal adhesive vs nonabsorbable microsuture in peripheral nerve repair. $J$ Hand Surg (Am). 1988;13:273-278.

18. Bento RF, Miniti A. Comparison between fibrin tissue adhesive, epineural suture and natural union in intratemporal facial nerve of cats. Acta Otolaringol Suppl. $1989 ; 465: 1-36$.

19. Benfrech E, Alnot JY, Henin D. Experimental study of nerve sutures and grafts of the sciatic nerve in the rat using fibrin glue. Ann Chir Main. 1989;8:296-9.

20. Gilbert A. Biological glue: experimental and clinical evidence. Ann Chir Main. 1989;8:302-11.

21. Mattar Jr, R. Reparação microcirúrgica de nervos periféricos - estudo comparativo entre a sutura epineural e o adesivo de fibrina. [dissertação]. São Paulo: Faculdade de Medicina, Universidade de São Paulo; 1989. 
22. Nishihira S, Mc Caffrey TV. Repair of motor nerve defects: Comparison of suture and fibrin adhesive techniques. Otolaryngol Head Neck Surg. 1989;100: $17-21$.

23. Jin Y, Dehesdin D, Hemet J, D'Arc CB, Creissard P, Tadie M. Étude expérimentale comparative des reparations nerveuses par suture classique ou par colle biologique. Neurochirurgie. 1990;36:378-382.

24. Maragh H, Meyer BS, Davenport D, et al. Morphofunctional evaluation of fibrin glue versus microsuture nerve repairs. J Reconstr Microsurg. 1990;6:331-7.

25. Zhou S. Anastomosis of peripheral nerve by fibrin glue. Zhonghua Wai Ke Za Zhi. 1990;28:682-92.

26. Povlsen B. A new fibrin seal in primary repair of peripheral nerves. J Hand Surg (Br). 1994;19:43-7.

27. Inalöz SS, Ak HE, Vayla V, Akin M, Aslan A, Sari I, Çelik Y, Özkan Ü. Comparison of microsuturing to the use of tissue adhesives in anastomosing sciatic cuts in rats. Neurosurg Rev. 1997;20:250-8.

28. Sames M, Blahos J Jr, Rokyta R, Benes Jr V. Comparison of microsurgical suture with fibrin glue connection of the sciatic nerve in rabbits. Physiol Res. 1997;46:303-6. 
29. Zhang C, Gu Y, Chen L. Experimental study of fibrin glue with epineural anchor suture to repair peripheral nerves. Zhongguo Xiu Fu Chong Jian Wai Ke Za Zhi. 1998;12:129-32.

30. Suri A, Mehta VS, Sarkar C. Microneural anastomosis with fibrin glue: an experimental study. Neurol India. 2002;50:23-6.

31. Karfunkel P. The mechanisms of neural tube formation. Int Rev Cytol. $1974 ; 38: 245-71$.

32. Langman J, Guerrant RL, Freeman BG. Behaviour of neuroepitelial cells during closure of the neural tube. J Comp Neurol. 1966;127:399-412.

33. Aszmann OC. The life and work of Theodore Schwann. J Reconstr Microsurg. 2000;16:291-5.

34. Asbury AK. Schwann cell proliferation in developing mouse sciatic nerve. J Cell Biol. 1967;34:735-43.

35. Mirsky R, Jessen KR, Brennan A, Parkinson D, Dong Z, Meier C, Parmantier E, Lawson D. Schwann cells as regulators of nerve development. J Physiol (Paris). 2002;96:17-24. 
36. Jessen KR, Mirsky R. Schwann cells and their precursors emerge as major regulators of nerve development. Trends Neurosci. 1999;22:402-10.

37. Gamble HJ. Further electron microscope studies of human foetal peripheral nerves. J Anat. 1966;100:487-502.

38. Carbonetto D, Gruver MM, Turner DC. Nerve fiber growth in culture on fibronectin, collagen and glycosaminoglycan substrates. $J$ Neurosci. $1983 ; 3: 2324-35$.

39. Ochoa J. The sural nerve of the human foetus: electron microscope observations and counts of axons. J Anat. 1971;108:231-45.

40. Parkinson DB, Bhaskaran A, Droggiti A, Dickinson S, D’Antonio M, Mirsky R, Jessen KR. Krox-20 inhibits Jun-NH $\mathrm{N}_{2}$ kinase/c-Jun to control Schwann cell proliferation and death. J Cell Biol. 2004;164:387-94.

41. Peirano RI, Goerich DE, Riethmacher D, Wegner M. Protein zero gene expression is regulated by the glial transcription factor Sox 10. Mol Cell Biol. 2000;20:3198-209.

42. Jessen KR, Mirsky R. Signals that determine Schwann cell identity. J Anat. 2002;200:367-76. 
43. Maier M, Berger P, Nave KA, Suter U, Identification of the regulatory region of the peripheral myelin protein 22 (PMP22) gene that directs temporal and spatial expression in development and regeneration of peripheral nerves. Mol Cel Neurosci. 2002;20:93-109.

44. Scherer SS. The biology and pathobiology of Schwann cells. Curr Opin Neurol. 1997;10:386-97.

45. Brennan A, Dean CH, Zhang AL, Cass DT, Mirsky R, Jessen KR. Endothelins control the timing of Schwann cell generation in vitro and in vitro. Dev Biol. $2000 ; 227: 545-57$.

46. Boyd JG, Gordon T. Neurotrophic factors and their receptors in axonal regeneration and functional recovery after peripheral nerve injury. Mol Neurob. $2003 ; 27: 277-323$.

47. Chen ZL, Strickland S. Laminin $\gamma 1$ is critical for schwann cell differentiation, axon myelination, and regeneration in the peripheral nerve. $J$ Cell Biol. 2003;163:889-99.

48. Kil S, Krull C, Cann G, Bronner-Fraser M. The alpha4 subunit of integrin is important for neural crest cell migration. Dev Biol. 1998;202:29-42. 
49. Stone DM, Hynes M, Armanini M, Swanson TA, Gu O, Johnson RL, Scott MP, Pennica D, Goddard A, Phillips H, Noll M, Hooper JE, De Saviage F, Rosenthal A. The tumour-suppressor gene patched encodes a candidate receptor for sonic hedgehog. Nature. 1996;384:129-34.

50. Parmantier E, Lynn B, Lawson D, Turmaine M, Namini SS, Chakrabarti L, Mc Mahon AP, Jessen KR, Mirsky R. Schwann cell-derived Desert hedgehog controls the development of peripheral nerve sheaths. Neuron. 1999;23:713-24.

51. Hinson AW. Schwann cells modulate sodium channel expression in spinal sensory neurons in vitro. Glia. 1997;21:339-49.

52. Friede RL, Samorajski T. Myelin formation in the sciatic nerve of the rat. A quantitative electron microscopic, histochemical and radioautographic study. $J$ Neuropathol Exp Neurol. 1968;27:546.

53. Previtali SC, Feltri ML, Archelos JJ, Quattrini A, Wrabetz L, Hartung H. Role of integrins in the peripheral nervous system. Progr Neurobiol. 2001;64: 35-49.

54. Helms AW, Johnson JE. Specification of dorsal spinal cord interneurons. Curr Opin Neurob. 2003;13:42-9.

55. Patten BM. Development of the nervous system. In: Patten BM, editor Human embriology. New York: The Blakiston Company; 1953. p.315-79. 
56. Garcia SML, Fernández CG. Desenvolvimento do sistema nervoso. In: Garcia SML, Fernández CG, editores. Embriologia. Porto Alegre: Artmed Editora; 2001. p.317-26.

57. Pannese E. The histogenesis of the spinal ganglia. Arch Anat Embryol Cell Biol. 1979;47:1-97.

58. Westerfield M, Eisen JS. Neuromuscular specificity: pathfinding by identified motor growth cones in a vertebrate embryo. Trends Neurosci. 1988;11:18-21.

59. Madison RD, Zomorodi A, Robinson GA. Netrin-1 and peripheral nerve regeneration in the adult rat. Exp Neurol. 2000;161:563-70.

60. Kaehn K, Jacob HJ, Christ B, Hinrichsen R, Poelmann RE. The onset of myotome formation in the chick. Anat Embryol. 1988;177:191-201.

61. Gamble JG. Development and maturation of the neuromusculoskeletal system. In: Morrissy RT, Weinstein SL, editores. Pediatric Orthopaedics. 4 th ed. Philadelphia: Lippincott Company; 2001;p.1-24.

62. Christ B, Jacob HJ, Jacob M. Experimental analysis of the origin of the wing musculature in avian embryos. Anat Embryol. 1977;150:171-86. 
63. Dietz FR, Marcuende JA. Embriology and development of the musculoskeletal system. In: Morrissy RT, Weinstein SL. Pediatric Orthopaedics. Philadelphia: Lippincott Company;2001.p.1-32.

64. Kelley RO. Early development of the vertebrate limb: an introduction to morphogenetic tissue interactions using scanning electron microscopy. Scan Electron Microsc. 1985;11:827-36.

65. Sunderland S. Terms relating to the structure of nerve fibers and nerve trunks. In: Sunderland S, editor. Nerve injuries and their repair. 2 nd ed. New York: Churchill Livingstone Inc; 1991. p.13-16.

66. Olsson Y. Microenvironment of the peripheral nervous system under normal and pathological conditions. Crit Rev Neurobiol. 1990;5:265.

67. Jabaley ME, Wallace WH, Heckler FR. Internal topography of major nerves of the forearm and hand. A current view. J Hand Surg (Br). 1980;51:1-18.

68. Myers RR. Anatomy and microanatomy of peripheral nerve. Neurosurg Clin N Am. 1991;2:1-20.

69. Paetau M, Mellström K, Vaheri A, Haltia M. Distribution of a major connective tissue protein, fibronectin in normal and neoplastic human nerve tissue. Acta Neuropathol (Berl). 1980;51:47-51. 
70. Baker MD. Electrophysiology of mammalian Schwann cells. Prog Biophys Mol Biol. 2002;78: 83-103.

71. Rutka JT, Apodaca G, Stern R, Rosenblum M. The extracellular matrix of the central and peripheral nervous systems: structure and function. $J$ Neurosurg. 1988;69:155-70.

72. Timple R. Macromolecular organization of basement membranes. Curr Opin Cell Biol. 1996;8:618-24.

73. Sanes JR. Roles of extracellular matrix in neural development. Annu Rev Physiol. 1983;45:581-600.

74. Siironen J, Sandberg M, Vuorinen V, Roytta M. Expression of type I and III collagens and fibronectin after transection of rat sciatic nerve: reinnervation compared to denervation. Lab Invest. 1992;67:80-7.

75. Nath RK, Kwon B, Mackinnon SE, Jensen JN, Reznik S, Boutros S. Antibody to transforming growth factor beta reduces collagen production in injured peripheral nerve. Plast Reconstr Surg. 1998;102:1100-6.

76. Junqueira LCU, Montes GS, Bezerra MS. Do Schwann cells produce collagen type III ? Experientia. 1978;35:114. 
77. Carey DJ, Eldridge CF, Cornbrooks CJ, Timpl R, Bunge RP. Biosynthesis of type IV collagen by cultured rat Schwann cells. J Cell Biol. 1983;97:473-9.

78. Furukawa R, Fechhecmer M. The structure, function and assemblet of actin filaments bundles. Int Rev Cytol. 1997;175:29-90.

79. Baas PW. The neuronal centrosome as a generator of microtubules for the axon. Curr Top Dev Biol. 1996;33:281-98.

80. Lee MK, Cleveland DW. Neuronal intermediate filaments. Annu Rev Neurosci. 1996;19: 187-217.

81. Sunderland S, Roche AF. Axon-myelin relationships in peripheral nerve fibres. Acta Anatomica. 1958 33:1.

82. Celio MR. The Schmidt-Lantermann incisures of the myelin sheath of Mauthner axons: places of longitudinal growth of myelin? Brain Res. 1976;108:221.

83. Shapiro L, Doyle JP, Hensley P, Colman DR, Hendrickson WA. Crystal structure of the extracellular domain from Po, the major structural protein of peripheral nerve myelin. Neuron. 1996;17:435-40.

84. Gamble HJ, Eames RA. An electron microscope study of the connective tissues of human peripheral nerve. J Anat. 1964;98:655-62. 
85. Bolin LM, Shooter EM. Neurons regulate Schwann cell genes by diffusible molecules. J Cell Biol. 1993;123:237-43.

86. Sunderland S. Connective tissues of nerve trunks. In: Sunderland S, editor. Nerve injuries and their repair. 2 nd ed. New York: Churchill Livingstone Inc; 1991. p.47-52.

87. Thomas PK, Olsson Y. Microscopic anatomy and function of the connective tissue components of peripheral nerve. In: Dick PK, Thomas PK, Lambert EH, Bunge ER, editores. Peripheral Neuropathy. Philadelphia: WB Saunders Company; 1984. p.97-120.

88. Sunderland S, Bradley K. The cross sectional area of peripheral nerve trunks devoted to nerve fibers. Brain. 1949;72:75-92.

89. Oldfors A. Macrophages in peripheral nerves: an ultrastructural and enzyme histochemical study on rats. Acta Neuropathol (Berl). 1980;49:43-9.

90. Brown MJ, Pleasure DE, Asbury AK. Microdissection of peripheral nerve: collagen and lipid distribuition with morphological correlation. J Neurol Sci. 1976;29:361-9. 
91. Thomas PK, Bhagat S. The effect of extraction of the intrafascicular contents of peripheral nerve trunks on perineurial structure. Acta Neuropathol (Berl). 1978;43:135-41.

92. Sunderland S. Lymphatics. Endoneurial spaces. Nervi nervorum. In: Sunderland S, editor. Nerve injuries and their repair. 2 nd ed. New York: Churchill Livingstone Inc; 1991. p.61.

93. Clarke E, Bearn JG. The spiral bands of Fantana. Brain. 1972;95:1.

94. Adams WE. Blood supply of nerves. J Anat. 1942;76:323-41.

95. Lundborg G. Structure and function of the intraneural microvessels as related to trauma, edema formation and nerve function. J Bone Joint Surg (Am). 1975; $57: 938-48$.

96. Smith JW. Factors influencing nerve repair. II: collateral circulation of peripheral nerves. Arch Surg. 1966;93:433-7.

97. Sunderland S. Blood supply of nerves. In: Sunderland S, editor. Nerve injuries and their repair. 2 nd ed. New York: Churchill Livingstone Inc; 1991. p.53-60.

98. Sunderland S. Nerve fibers. In: Sunderland S, editor. Nerve injuries and their repair. 2 nd ed. New York: Churchill Livingstone Inc; 1991. p.17-26. 
99. Tashiro T, Komiya Y. Changes in organization and axonal transport of cytoskeletal proteins during regeneration. J Neurochem. 1991;56:1557-63.

100. Vance JE, Campenot RB, Vance DE. The synthesis and transport of lipids for axonal growth and nerve regeneration. Biochim Biophys Acta. 2000;1486:8496.

101. Brady ST, Lasek RJ, Allen RD. Fast axonal transport in extruded axoplasm from squid giant axon. Science. 1982; 218:1129-31.

102. Droz B, Rambourg A, Koenig HL. The smooth endoplasmic reticulum. Structure and role in the renewal of axonal membrane and synaptic vesicles by fast axonal transport. Brain Res. 1975;93:1-13.

103. Friedman WA. The electrophysiology of peripheral nerve injuries. Neurosurg Clin N Am. 1991;2:43-56.

104. Huxley AF, Stämpfli R. Evidence for saltatory conduction in peripheral myelinated fibers. J Physiol. 1949;108:315-39.

105. Kocsis JD, Waxman SG. Membrane organization and myelin remodeling in regenerating axons. Adv Neurol. 1988;47:31-49. 
106. Amstrong C, Hille B. Voltage-gated ion channels and electrical excitability. Neuron. 1998;20:37-80.

107. Jan L, Jan Y. Cloned potassium channels from eukaryotes and prokaryotes. Ann Rev Neurosci. 1997;20:91-124.

108. Engh CA, Schofield BH. A review of the central response to peripheral nerve injury and its significance in nerve regeneration. J Neurosurg. 1972;37:198203.

109. Zigmond RE. Can galanin also be considered as growth-associated protein 3.2 ?. Trends Neurosci. 2001;9:494-5.

110. Ducker TB, Kaufman FC. Metabolic factors in the surgery of peripheral nerves. Clin Neurosurg. 1977;24:406-24.

111. Grafstein B. The nerve cell body response to axonotomy. Exp Neurol. $1975 ; 48: 32-51$.

112. Terenghi G. Peripheral nerve regeneration and neurotrophic factors. J Anat. $1999 ; 194: 1-14$

113. Vogelaar CF, Hoekman MFM, Brakkee JH, Bogerd J, Burbach JPH. Developmental regulation of homeobox gene expression in dorsal adult root 
ganglia neurons is not recapitulated during regeneration of the crushed sciatic nerve regeneration. Neuroscience. 2004;125:645-50.

114. Kubo T, Yamashita T, Yamaguchi A, Hosokawa K, Tohyama M. Analysis of genes induced in peripheral nerve after axotomy using cDNA microarrays. $J$ Neurochem. 2002;82:1129-36.

115. Zheng J, Kelly TK, Chang B, Ryazantsev S, Rajasekaran AK, Martin KC, Twiss JL. A functional role for intra-axonal protein synthesis during axonal regeneration from adult sensory neurons. $J$ Neurosci. 2001;21:9291-303.

116. Liuzzi FJ, Tedeschi B. Peripheral nerve regeneration. Neurosurg Clin N A.m $1991 ; 2: 31-42$.

117. Wong BJ, Crumley RL. Nerve wound healing: an overview. Otolaryngol Clin North Am. 1995;28:881-95.

118. Waxman SG, Kocsis JD, Black JA. Type III sodium channel mRNA is expressed in embryonic but not adult spinal sensory neurons, and is reexpressed following axotomy. J Neurophysiol. 1994;72:466-70.

119. Bontioti EN, Kanje M, Dahlin LB. Regeneration and functional recovery in the upper extremity of rats after various types of nerve injuries. J Peripher Nerv Syst. 2003;8:159-68. 
120. Avellino AM, Dailey AT, Harlan JM, Sharar SR, Winn RK, McNutt LD, Kliot M. Blocking of up-regulated ICAM-1 does not prevent macrophage infiltration during Wallerian degeneration of peripheral nerve. Exp Neurol. 2004;187:430-44.

121. Goodrum JE, Bouldin TW. The cell biology of myelin degeneration and regeneration in the peripheral nervous system. J Neuropathol Exp Neurol. 1996;55:943-53.

122. Evans PJ, MacKinnon SE, Midha R, Wade JA, Hunter DA, Nakao Y, Hare GM. Regeneration across cold preserved peripheral nerve allografts. Microsurgery. 1999;19:115-27.

123. Bruck W. The role of macrophages in Wallerian degeneration. Brain Pathol. $1997 ; 7: 741-52$.

124. Dailey AT, Avellino AM, Benthem L, Silver J, Kliot M. Complement depletion reduces macrophage infiltration during Wallerian degeneration and axonal regeneration. J Neurosci. 1998;6713-722.

125. De Jonge RR, Van Schaik IN, Vreijling JP, Troost D, Baas F. Expression of complement components in the peripheral nervous system. Hum Mol Genet. 2004;13:295-302. 
126. Durrenberger PF, Facer P, Gray RA, Chessell IP, Naylor A, Bountra C, Banati RB, Birch R, Anand P. Cyclooxygenase-2 (Cox-2) in injured human nerve and a rat model of nerve injury. J Peripher Nerv Syst. 2004;9:15-25.

127. Mercier G, Turque N, Schumacher M. Early activation factor expression in Schwann cells by progesterone. Brain Res. 2001;97:137-48.

128. La Fleur M, Underwood JL, Rappolee DA, Werb Z. Basement membrane and repair of injury to peripheral nerve: defining a potential role for macrophages, matrix metalloproteinases, and tissue inhibitor of metalloproteinases-1. $J$ Exp Med. 1996;184:2311-26.

129. Torigoe K, Tanaka H, Takahashi A, Awaya A, Hashimoto K. Basic behavior of migratory Schwann cells in peripheral nerve regeneration. Exp Neurol. 1996;137:301-8.

130. Son Y, Thompson WJ. Schwann cell processes guide regeneration of peripheral axons. Neuron. $1995 ; 14: 125-32$.

131. Gordon T, Sulaiman O, Boyd JG. Experimental strategies to promote functional recovery after peripheral nerve injuries. J Peripher Nerv Syst. $2003 ; 8: 236-50$. 
132. Ceballos D, Lago N, Verdú E, Penkowa M, Carrasco J, Navarro X, Palmiter RD, Hidalgo J. Role of metallothioneins in peripheral nerve function and regeneration. Cell Mol Life Sci. 2003;60:1209-16.

133. Buettner HM. Nerve growth dynamics. Quantitative models for nerve development and regeneration. Ann N Y Acad Sci. 1994;745:211-21.

134. Landis SC. Neuronal growth cones. Annu Rev Physiol. 1983;45:567-80.

135. Yamada KM, Spooner BS, Wessells NK. Ultrastructure and function of the growth cones and axons of cultured nerve cells. J Cell Biol. 1971;49:614-35.

136. Berry M, Hall S, Shewan D, Cohen J. Axonal growth and its inhibition. Eye. $1994 ; 8: 245-54$

137. Gomez TM, Snow DM, Letourneau PC. Characterization of spontaneus calcium transients in nerve growth cones and their effects on growth cone migration. Neuron. 1995;14:1233-46.

138. Torigoe K, Lundborg G. Selective inhibition of early axonal regeneration by myelin-associated glycoprotein. Exp Neurol. 1998;150:254-62.

139. Evans GRD. Challenges to nerve regeneration. Semin Surg Oncol. 2000;19:312-8. 
140. Südhof TC. Synaptic vesicle cycle: a cascade of protein-protein interactions. Nature. 1995;357:645-53.

141. Südhof TC, Jahn R. Proteins of synaptic vesicles involved in exocytosis and membrane recycling. Neuron. 1991;6:665-77.

142. Strittmatter SM, Igarashi M, Fishman MC. GAP-43 amino terminal peptides modulate growth cone morphology and neurite outgrowth. J Neurosci. 1994;14: 5503-13.

143. Bixby JL, Jhabvala P. Extracellular matrix molecules and cell adhesion molecules induce neurites through different mechanisms. J Cell Biol. 1990;111:2725-32.

144. Wiklund P, Ekström AR, Edbladh M, Tonge D, Edström A. Protein kinase C and mouse sciatic nerve regeneration. Brain Res. 1996;715:145-54.

145. Miyamoto S, Teramoto H, Coso OA, Gutkind JS, Burbelo PD, Akiyama SK, Yamada KM. Integrin function: molecular hierarchies of cytoskeletal and signaling molecules. J Cell Biol. 1995;131:791-805.

146. Chernousov MA, Carey DJ. AV $\beta 8$ integrina is a Schwann cell receptor for fibrin. Exp Cell Res. 2003;291:514-24. 
147. Shibuya Y, Mizoguchi A, Takeichi M, Shimada K, Ide C. Localization of Ncadherin in the normal and regenerating nerve fibers of the chicken peripheral nervous system. Neuroscience. 1995;67:253-61.

148. Jaakola S, Peltonen J, Uitto J. Perineurial cells coexpress genes encoding interstitial collagens and basement membrane zone components. J Cell Biol. 1989;108:1157-63.

149. Meier C, Parmantier E, Brennan A, Mirsky R, Jessen KR. Developing Schwann cells acquire the ability to survive without axons by establishing an autocrine circuit involving insulin-like growth factor, neurotrophin-3 and plateletderived growth factor-BB. J Neurosci. 1999;19:3847-59.

150. Tetzlaff WC, Leonard CA, Krekoski IM, Parhad IM, Bisby MA. Reductions in motoneuronal neurofilament synthesis by successive axonotomies: a possible explanation for the conditioning lesion effect on axon regeneration. Exp Neurol. 1996;139:95-106.

151. Torigoe K, Hashimoto K, Lundborg G. A role of migratory Schwann cells in a conditioning effect of peripheral nerve regeneration. Exp Neurol. 1999;160:99-108.

152. Pettmann B, Henderson CE. Neuronal cell death. Neuron. 1998;20:633-47. 
153. Chan YM, Yick L, Yip HK, So K, Oppenheim RW, Wu W. Inhibition of caspases promotes long-term survival and reinnervation by axotomized spinal motoneurons of denervated muscles in newborn rats. Exp Neurol. 2003;181:190-203.

154. Anton ES, Weskamp G, Reichardt LF, Matthew WD. Nerve growth factor and its low-affinity receptor promote Schwann cell migration. Proc Nat Acad Sci USA. 1994;91:2795-9.

155. Heumann R, Korshing S, bandtlow C, Thoenen H. Changes of nerve growth factor synthesis in non-neuronal cells in response to sciatic nerve transection. J Cell Biol. 1987;104:1623-31.

156. Lindholm D, Heumann R, Meyer M, Thoenen H. Interleukin-1 regulates synthesis of the nerve growth factor in non-neuronal cells of rat sciatic nerve. Nature. 1987;330:658-9.

157. Meyer M, Matsuoka I, Wetmore C, Olson L, Thoenen H. Enhanced synthesis of brain-derived neurotrophic factor in the lesioned peripheral nerve: different mechanisms are responsible for the regulation of BDNF and NGF mRNA. $J$ Cell Biol. 1992;119:45-54.

158. Da Silva CF. Fatores neurotróficos: estrutura, funções e aplicações clínicas. Atualização em Neurociências. 1995;1:1-20. 
159. Klein, HW, Kilmer S, Carlsen RC Enhancement of peripheral nerve regeneration by pharmacological activation of cyclic AMP second messenger system. Microsurgery. 1989;10:122-125.

160. Lainetti RD, Da Silva CF. Local addition of monosialoganglioside GM1 stimulates peripheral axon regeneration in vivo. Braz J Med Biol Res. 1993;26: 841-845.

161. Tong JX, Rich KM. Diphenylpiperazines enhance regeneration after facial nerve injury. J. Neurocytol. 1997;26:339-47.

162. Brushart TM. Motor axons preferentially reinnervate motor pathways. $J$ Neurosci. 1993;13:2730-8.

163. Zuo J, Neubauer D, Graham J, Krekoski CA, Ferguson TA, Muir D. Regeneration of axons after nerve transection repair is enhanced by degradation of chondroitin sulfate proteoglycan. Exp Neurol 2002;176:221-8.

164. Tonge DA, Golding JP, Edbladh M, Kroon M, Ekström PER, Edström A. Effects of extracellular matrix components on axonal outgrowth from peripheral nerves of adult animals in vitro. Exp Neurol. 1997;146:81-90. 
165. Hughes PM, Wells GMA, Perry VH, Brown MC, Miller KM. Comparison of matrix metalloproteinase expression during Wallerian degeneration in the central and peripheral nervous systems. Neuroscience. 2002;113:273-87.

166. Monard D. Cell-derived proteases and protease inhibitors as regulators of neurite outgrowth. Trends Neurosci. 1988;11:541-4.

167. De Medinaceli L, Freed WJ, Wyatt RJ. An index of the functional condition of rats sciatic nerve based on measurements made from walking tracks. Exp Neurol. 1982;77:634-643.

168. Bain JR, Mackinnon SE, Hunter DA Functional evaluation of complete sciatic, peroneal, and posterior tibial nerve lesions in the rat. Plast Reconstr Surg. $1989 ; 83: 129-136$.

169. Dellon AL, Mackinnon SE. Selection of the appropriate parameter to measure neural regeneration. Ann Plast Surg. 1989;23:197-202.

170. Hare GMT, Evans PJ, Mackinnon SE, Best TJ, Bain JR, Szalai JP, Hunter DA. Walking track analysis: a long-term assessment of peripheral nerve recovery. Plast Reconstr Surg. 1992;89:251-8. 
171. Kanaya F, Firrell JC, Breidenbach WC. Sciatic function index, nerve conduction tests, muscle contraction and axon morphometry as indicators of regeneration. Plast Reconstr Surg. 1996;98:1264-71.

172. Dellon AL, Mackinnon SE. Sciatic nerve regeneration in the rat. Validity of walking track assessment in the presence of chronic contractures. Microsurgery. 1989;10:220-5.

173. Carr MM, Best TJ, Mackinnon SE, Evans PJ. Strain differences in autotomy in rats undergoing sciatic nerve transection or repair. Ann Plast Surg. 1992;28:538-44.

174. Weber RA, Proctor WH, Warner MR, Verheyden CN. Autotomy and the sciatic functional index. Microsurgery 1993;14:323-7.

175. Wall PD, Gutnick M. Ongoing activity in pheripheral nerves: the physiology and phamacology of impulses originating from a neuroma. Exp Neurol. 1987;43:580-93.

176. Publicover NG, Terzis JK. Physiologic assessment of nerve injuries. In: Terzis JK. Microreconstruction of nerve injuries. Philadelphia: WB Saunders; 1987. p. $83-95$. 
177. Waxman SG. Structure-function relations in nerves and nerve injuries. In: Jewett DL, McCarroll Jr. HR, editores. Nerve repair and regeneration. Its clinical and experimental basis. St Louis: The CV Mosby Company; 1980. p.186-96.

178. Rosen JM, Jewett DL. Physiological methods of evaluating experimental nerve repairs. In: Jewett DL, McCarroll Jr. HR, editores. Nerve repair and regeneration. Its clinical and experimental basis. St Louis: The CV Mosby Company; 1980. p.150-161.

179. Terzis JK, Smith KJ. Repair of severed peripheral nerves: comparison of the 'de Medinaceli' and standard microsuture methods. Exp Neurol. 1987;96:672-80.

180. Munro CA, Szalai JP, Mackinnon SE, Midha R. Lack of association between outcome measures of nerve regeneration. Muscle Nerve. 1998;21:1095-7.

181. Oliveira EF, Mazzer N, Barbieri CH, Selli M. Correlation between functional index and morphometry to evaluate recovery of the rat sciatic nerve following crush injury: experimental study. J Reconstr Microsurg. 2001;17:69-75.

182. Little KM, Zomorodi AR, Selznick LA, Friedman AH. An ecletic history of peripheral nerve surgery. Neurosurg Clin N Am.2004;15:109-23. 
183. Almquist E. Adjuncts to suture repair of peripheral nerves: laser, glue and other techniques. In: Omer GE, Spinner M, Van Beek AL, editores. Management of peripheral nerve Problems. 2 nd ed. Philadelphia: WB Saunders; 1998. p.311-8.

184. Naff NJ, Ecklund JM. History of peripheral nerve surgery techniques. Neursurg Clin N Am. 2001;12:197-209.

185. Highet WB, Sanders FK. The effects of stretching nerves after suture. $\mathrm{Br} J$ Surg. 1943;30:355-69.

186. Mackinnon SE, Dellon AL. Nerve repair and nerve grafting. In: Mackinnon SE, Dellon AL, editores. Surgery of the peripheral nerve. New York: Thieme;1988. p. 89-129.

187. Seddon HJ. The use of autogenous grafts for the repair of large gaps in peripheral nerves. Br J Surg. 1947;35:151-67.

188. Sunderland S. The intraneural topography of the radial, median and ulnar nerves. Brain. 1945;68:243-98.

189. Millesi H, Berger A, Meissl G. Experimentelle untersuchungen zur heilung durchtrennter peripherer nerven. Chir Plast. 1972; 1:174-9. 
190. Ballance CA, Duel AB. The operative treatment of facial palsy by introduction of nerve grafts into fallopian canal and other intratemporal methods. Arch Otolaryngol. 1932;15:1-70.

191. Tarlov IM. Autologous plasma clot suture of nerves: its use in clinical surgery. JAMA. 1944;126:741-9.

192. Millesi H. Nerve grafts: indications, techniques and prognoses. In: Omer Jr GE, Spinner M, Van Beek AL, editores. Management of peripheral nerve problems. Philadelphia: WB Saunders Company;1998. p. 280-9.

193. Meek MF, Coert JH. Clinical use of nerve conduits in peripheral-nerve repair: review of the literature. J Reconstr Microsurg. 2002;18:97-109.

194. Fields RD, Le Beau JM, Longo FM, Elissman MH. Nerve regeneration through artificial tubular implants. Prog Neurobiol. 1989;33:87-134.

195. Weiss P. The technology of nerve regeneration: sutureless tubulation and related methods of nerve repair. Neurosurgery. 1944;1:400-50.

196. Dellon AL, Mackinnon SE. An alternative to the classical nerve graft for the management of the short nerve gap.Plast Reconstr Surg. 1988;82:849-56. 
197. Dahlin LB, Lundborg G. Use of tubes in peripheral nerve repair. Neurosurg Clin N Am. 2001;12:341-52.

198. Lundborg G, Rosen B, Dahlin L. Tubular versus conventional repair of the median and ulnar nerves in the human forearm. Early results from a prospective, randomized, clinical study. J Hand Surg (Br). 1997;22:1-8.

199. Braga-Silva J. The use of silicone tubing in the late repair of the median and ulnar nerves in the forearm. J Hand Surg (Br). 1999; 24:703-6.

200. Weber RA, Breidenback WC, Brown RE. A randomized prospective study of polyglycolic acid conduits for digital nerve reconstruction in humans. Plast Reconstr Surg. 2000;106:1036-45.

201. Lundborg G, Rosen B, Dahlin L, Holmberg J, Rosen I. Tubular repair of the median or ulnar nerve in the human forearm: a 5-year follow-up. J Hand Surg (Br). 2004;29:100-7.

202. Kline DG, Hayes GJ. The use of resorbable wrapper for peripheral nerve repair. Experimental studies in chimpanzes. J Neurosurg 1964;21:737-50.

203. Freeman BS. Adhesive neural anastomosis. Plast Reconstr Surg. 1965;35:16776. 
204. Brown DG. Surgical tape (micropore) as a substitute for sutures in nerve repair. Tex Med. 1968;64:52-5.

205. Prevel CD, Eppley BL, McCarty M, Brock C. Mechanical anastomosis of nerves: a histological and functional comparison to conventional suturing. Ann Plast Surg. 1994;33:600-5.

206. Park JW, Lee KS, Kim SK, Park JH, Honk JS, Oh, KJ. Rapid neurorrhaphy with titanium clips. Microsurgery. 2002;22:386-90.

207. DeLee JC, Smith MT, Green DP. The reaction of nerve tissue to various suture materials: a study in rabbits. J Hand Surg (Am). 1977;2:38-43.

208. Cham RB, Peimer CA, Howard CS, Walsh WP, Eckert BS. Absorbable versus nonabsorbable suture for microneurorrhaphy. J Hand Surg (Am). 1984;9:43440.

209. Sunderland S. Factors influencing the quality of the recovery after nerve repair. In: Sunderland S, editor. Nerve injuries and their repair. 2 nd ed. New York: Churchill Livingstone Inc; 1991. p.395-412.

210. Hudson AR, Hunter D. Polyglycolic acid suture in peripheral nerve, II: sutured sciatic nerve. Can J Neurosci. 1976;3:69-72. 
211. Bratton BR, Kline DG, Hudson AR, Coleman WT. Use of monofilament polyglycolic acid suture for experimental peripheral nerve repair. J Surg Res. 1981;31:482-9.

212. Van Beek AL, Pirela-Cruz MA. Microsurgical nerve repairs. In: Omer Jr GE, Spinner M, Van Beek AL, editores. Management of peripheral nerve problems. Philadelphia: WB Saunders Company; 1998. p. 260-9.

213. Midha R, Mackay M. Principles of nerve regeneration and surgical repair. Semin Neurosurg. 2001;12: 81-93.

214. Gosain AK, Lyon VB. The current status of tissue glues: part II. For adhesion of soft tissues. Plast Reconstr Surg. 2002;110:1581-4.

215. Hurwitz PJ, Magora A, Gonen B, Appelboim J, Ben-Hur N. Microsurgical techniques and the use of tissue adhesive in the repair of peripheral nerves. $J$ Surg Res. 1974;17:245-52.

216. Siedentop KH, Loewy A. Facial nerve repair with tissue adhesive. Arch Otolaryngol. 1979;105:423-6.

217. Wieken K, Angioi-Duprez K, Lim A, Marchal L, Merle M. Nerve anastomosis with glue: comparative histologic study of fibrin and cyanoacrylate glue. $J$ Reconstr Microsurg. 2003;19:17-20. 
218. Sandvoss G, Cervos-Navarro J, Yasargil MG. Intracranial repair of the oculomotor nerve in cats. Neurochirurgia (Stuttg). 1986;29:1-8.

219. Wlodarczyk J. Effects of tissue glues on electrical activity in isolated nerve. Polim Med. 1991;2:37-41.

220. Iuan FC, Thomazini IA, Gianini MJ, Viterbo F, Toscano E, Moraes RA, Barravieira B. Reparation of peripheral nerves with fibrin glue prepared from snake venom. Preliminary results. São Paulo Med J. 1995;113:1000-2.

221. Parker G, White T, Jenkins R. Surgical repair of extratemporal facial nerve: a comparison of suture repair and microfibrillar collagen repair. Laryngoscope. 1984;94:950-3.

222. Martinowitz U, Spotnitz D. Fibrin tissue adhesives. Thromb Haemost. 1997;78:661-6.

223. Shigemitsu T, Majima Y. The utilization of a biological adhesive for wound treatment: comparison of suture, self-sealing sutureless and cyanoacrylate closure in the tensile strength test. Int Ophthalmol. 1997;20:323-8.

224. Gestring GF, Lerner R. Autologous fibrinogen for tissue-adhesion, hemostasis and embolization. Vasc Surg. 1983;17:294-304. 
225. Siedentop KH, Harris DM, Sanchez B. Autologous fibrin tissue adhesive. Laryngoscope. 1985;95:1074-6.

226. Gama SAM, Pereira EA, Paula EJL, Kimura LK, Rezende MR, Mattar Jr. R, Omoto R, Okane S, Azze RJ. Adesivo autólogo de fibrina. Acta Ortop Bras. $1997 ; 5: 1-5$.

227. Buckley RC, Breazeale EE, Edmond JA, Brezezienski MA. A simple preparation of autologous fibrin glue for skin-graft fixation. Plast Reconstr Surg. 1999;103:202-6.

228. Dunn CJ, Goa KL. Fibrin sealant. A review of its use in surgery and endoscopy. Drugs. 1999;58:863-86.

229. Jubran M, Widenfalk J. Repair of peripheral nerve transections with fibrin sealant containing neurotrophic factors. Exp Neurol. 2003;18: 204-12.

230. Tabata S, Eckert HG, Kellner HM. Pharmacokinetic study of a fibrin adhesive agent, Beriplast ${ }^{\circledR}$ in rats. Pharmacometrics. 1986;311:1123-7.

231. Herter T, Anagnostopoulos-Schleep J, Bennefeld H. The effect of fibrin glueing and its important components on fibrosis of nerve anastomoses. Unfallchirurgie. 1989;15:221-9. 
232. Medders G, Mattox DE, Lyles A. Effects of fibrin glue on rat facial nerve regeneration. Otolaryngol Head Neck Surg. 1989;100:106-9.

233. Palazzi S, Villa-Torres J, Lorenzo JC. Fibrin glue is a sealant and not a nerve barrier. J Reconstr Microsurg. 1995;11:135-9.

234. Narakas A. The use of fibrin glue in repair of peripheral nerves. Orthop Clin North Am. 1988;19:187-199.

235. Boedts D. A comparative experimental study on nerve repair. Arch Otorhinolaryngol. 1987;244:1-6.

236. Matras H, Braun F, Lassman H, Ammerer HP, Mamoli B. Plasma clot welding of nerves. J Maxillofac Surg. 1973;1:236-47.

237. Matras H. Fibrin seal: state of the art. J Oral Maxillofac Surg. 1985;43:605-9.

238. Cazelles L, Wang J, Bouccara D, Sterkes O. Chirurgie intratemporale du nerf facial. A propos de 34 observations. Ann Otolaryngol Chir Cervicofac. $1997 ; 114: 23-8$.

239. Egloff DV, Narakas A. Nerve anastomoses with human fibrin. Preliminary clinical report (56 cases). Ann Chir Main. 1983;2:101-15. 
240. Rheiner P. Utilisation de la colle biologique dans la réparation du nerf périphérique. Helv Chir Acta. 1985;52:891-4.

241. Palazzi S. The use of fibrin sealant in nerve adhesions (peripheral nerves and plexus brachialis). In: Schlag G, Gedl H, editores. Ophthalmology, Neurosurgery. Berlin: Springer; 1986. p.186-91.

242. Kuderna H. Clinical application of nerve-anastomoses adhesion using fibrinogen. Fortschr Kiefer Gesichtschir. 1976;21:135-8.

243. Robinson GA, Madison RD. Preferential motor reinnervation in the mouse: comparison of femoral nerve repair using a fibrin sealant or suture. Muscle Nerve. 2003;28:227-31.

244. Becker C, Guening C, Grall G. Biological glue vs epineural suture in delayed peripheral nerve repair: experimental study in the rat. Ann Chir Main. $1985 ; 4: 259-262$.

245. Povlsen B. A new fibrin seal: functional evaluation of sensory regeneration following primary repair of peripheral nerves. $J$ Hand Surg (Br). $1994 ; 19: 250-4$. 
246. Menovsky T, Beek JF. Laser, fibrin glue, or suture repair of peripheral nerves: a comparative functional, histological, and morphometric study in the rat sciatic nerve. J Neurosurg. 2001;95:694-9.

247. Kim DH, Connolly SE, Voorhies RM, Beuerman RW, Kline DG. Initial evaluation of variable graft lengths and lesion lengths in the repair of nerve gaps. J Reconstr Microsurg. 1990;6:311-6.

248. He C, Chen Z, Chen Z. Enhancement of motor nerve regeneration by nerve growth factor. Microsurgery. 1992;13:151-4.

249. Watanabe O, Mackinnon SE, Tarasidis G, Hunter DA, Ball DJ. Long-term observation of the effect of peripheral nerve injury in neonatal and young rats. Plast Reconstr Surg. 1998;102:2072- 81.

250. Ijkema-Paassen J, Meek MF, Gramsbergen A. Reinnervation of muscles after transection of the nerve in adult rats. Muscle Nerve. 2002;25:891-7.

251. Shen N, Zhu J. Application of sciatic functional index in nerve functional assessment. Microsurgery. 1995;16:552-5.

252. Prusiner SB. Shattuck lecture - neurodegnerative diseases and prions. $N$ Engl J Med. 2001;44:1516-26. 
253. Gutman E, Sanders FK. Recovery of fiber numbers and diameters in the regeneration of peripheral nerves. J Physiol. 1943;101:489-518.

254. Mackinnon SE, Dellon AL, O'Brien JP. Changes in nerve fiber numbers distal to a nerve repair in the rat sciatic nerve model. Muscle Nerve. 1991;14: 111622. 